The Federal Reserve BanK of Kansas City Research Working Papers

\title{
Do Bank Bailouts Reduce or Increase Systemic Risk? The Effects of TARP on Financial System Stability
}

Allen N. Berger, Raluca A. Roman and John Sedunov

September 2016

RWP 16-08

https://dx.doi.org/10.18651/RWP2016-08 


\title{
Do Bank Bailouts Reduce or Increase Systemic Risk? The Effects of TARP on Financial System Stability*
}

\author{
Allen N. Berger ${ }^{\dagger}$ \\ University of South Carolina \\ Wharton Financial Institutions Center \\ European Banking Center \\ Raluca A. Roman* \\ Federal Reserve Bank of Kansas City \\ John Sedunov ${ }^{\S}$ \\ Villanova University
}

September 2016

\begin{abstract}
Theory suggests that bank bailouts may either reduce or increase systemic risk. This paper is the first to address this issue empirically, analyzing the U.S. Troubled Assets Relief Program (TARP). Difference-indifference analysis suggests that TARP significantly reduced contributions to systemic risk, particularly for larger and safer banks located in better local economies. This occurred primarily through a capital cushion channel. Results are robust to additional tests, including accounting for potential endogeneity and selection bias. Findings yield policy conclusions about the wisdom of bailouts, which banks might be the best targets for future bailouts, and the form these bailouts might take.
\end{abstract}

JEL Classification Codes: G18, G21, G28

Keywords: Bailouts, TARP, Banks, Systemic risk, Financial Crises

\footnotetext{
* The views expressed herein are those of the authors and do not necessarily reflect the views of the Federal Reserve Bank of Kansas City or the Federal Reserve System. The authors thank Jonatan Groba and participants in the European Banking Center Workshop at Lancaster University, the Interplay between Financial Regulations, Resilience, and Growth Conference at the Philadelphia Federal Reserve Bank, and the seminar at the Federal Reserve Bank of Kansas City for helpful comments.

${ }^{\dagger}$ Darla Moore School of Business, University of South Carolina, 1014 Greene Street, Columbia, SC 29208, E-mail: aberger@moore.sc.edu.

${ }^{\ddagger}$ Banking Research Department, Federal Reserve Bank of Kansas City, 1 Memorial Drive, Kansas City, MO 64198, E-mail: raluca.roman@kc.frb.org.

$\S$ Villanova School of Business, Villanova University, 800 Lancaster Avenue, 2065 Bartley Hall, Villanova, PA 19085.

E-mail: john.sedunov@villanova.edu.
} 


\section{Introduction}

Do bank bailouts reduce systemic risk, possibly rescuing the financial system from collapse, or do they alternatively encourage banks to take actions that increase their contributions to systemic risk, making the system more fragile? The theoretical literature is split on this issue. Some papers predict that bailouts can reduce systemic risk either through increasing charter value (Cordella and Levy-Yeyati, 2003), or through reducting undiversifiable contagion risk across banks (Freixas, Parigi, and Rochet, 2000; Allen and Gale, 2001; Diamond and Rajan, 2005; Dell'Ariccia and Ratnovski, 2013; Choi, 2014). Others predict that bailouts can increase systemic risk by exacerbating moral hazard problems (e.g., Diamond and Rajan, 2009; Farhi and Tirole, 2012) and/or creating strategic complementarities among banks, which encourage coordinated risk-taking behavior (Acharya and Yorulmazer, 2007, 2008).

Discussions about one particular bank bailout, the U.S. Troubled Assets Relief Program (TARP), are similarly divided. A major objective of TARP was to reduce systemic risk and prevent a financial collapse which could have dragged down the real economy. ${ }^{1}$ Some argue that it was successful in this regard (e.g., Krugman; 2009; Bernanke, 2009, 2015), while others argue that TARP caused banks to take actions that increase systemic risk (e.g., Rogoff, 2010; Barofsky 2011, 2012).

A major reason why this question is unsettled may be because there is no empirical research, to our knowledge, on the effects of TARP or bailouts in any other countries on systemic risk. Although some empirical studies examine the effects of bailouts on components of individual bank risk, we are aware of none that address systemic risk. The existing studies in particular deal only with the risks of parts of the portfolios of bailed-out banks, rather than their full contributions to systemic risk. This research does not include the rest of their portfolios, their capital, their size, their interconnectedness, and the correlations of their risks with the rest of the financial system, all of which help determine systemic risk.

To our knowledge, this is the first paper to provide empirical evidence to help break the tension between the opposing positions on the effects of bank bailouts on systemic risk. We formulate and test hypotheses representing both points of view to help determine which is more consistent with the evidence. We find evidence suggesting that TARP statistically and economically significantly reduced recipient banks' contributions to systemic risk, consistent with the arguments that bailouts reduce systemic risk. Our results are also robust to a number of different specifications.

The determination of whether and how bank bailouts decrease or increase systemic risk is of first-

\footnotetext{
${ }^{1}$ There are many other benefits and costs of the TARP program that are analyzed in the literature. See Calomiris and Khan (2015) and Berger and Roman (forthcoming) for reviews.
} 
order policy and research importance for several reasons. First, the consequences of bailouts may be relatively long-lived, affecting the financial system for considerable time afterwards. Second, bailouts usually take place during financial crises, which are recurring economic phenomena (e.g., Kindleberger, 1978; Reinhart and Rogoff, 2009; Fahlenbrach, Prilmeier, and Stulz, 2012). Therefore, when future financial crises occur and policy makers consider their options, it is helpful to know whether bailouts tend to combat systemic risk versus make the problem worse. Third, the effects of bailouts may differ across types of banks. Information on the relative effectiveness of bailouts for different types of banks is key to targeting any potential future bailouts. Fourth, bailouts may affect systemic risk through many different channels. Some of them operate through altering individual bank capital and leverage risk, others influence individual bank portfolio risk, and a third set involves increasing bank systemic importance. Knowledge of which channels are most effective may be valuable in the design of possible future bailouts and accompanying policies. Finally, there are a variety of bailout methods, including injections of preferred equity, blanket guarantees, extending liquidity support, nationalizations, and many others. Information on whether specific types of bailouts reduce or increase systemic risk may provide insights for designing the any future bailouts that might be considered. Here, we study the effects of one particular form of bailout, injections of preferred equity, as TARP did, and we encourage future research on the effects of other types of bailouts on systemic risk.

At first glance, it may seem obvious that injecting preferred equity capital into banks would reduce their contributions to systemic risk due to a capital cushion channel. The extra preferred equity provides a greater buffer to absorb losses and reduce the probabilities of financial distress and failure. The injections may raise the values of common equity shares because of this safety, making it easier to raise additional equity and reducing the likelihood of runs or panic selling of the common equity. In addition, higher preferred equity capital may reduce moral hazard incentives to take excessive risks that are engendered by deposit insurance and other aspects of the government safety net for banks. Portfolio risks may also be reduced because of extra explicit or implicit government restrictions on these institutions, such as limits on executive compensation or additional scrutiny of their portfolios.

However, there are other reasons why injections of preferred equity may alternatively increase recipient banks' systemic risk contributions. The values of common equity shares may decrease because of a capital priority channel. Preferred equity has priority over common equity, which may result in a decline in the value of common equity because of this subordination of its claims, increasing the difficulty of raising common equity and raising the probability of runs and panic selling of common equity. Bank portfolio risk might also increase because bailouts may increase bank moral hazard incentives to take on more portfolio risk by signaling that future bailouts are more likely. Finally, bailouts may increase the 
contributions to systemic risk of some banks in ways that are independent of any changes in their risks of individual bank failure. Bailouts may encourage banks to become larger or more interconnected to increase the probabilities of future bailouts because of heightened perceptions of too-big-to-fail (TBTF) or toointerconnected-to-fail (TITF) protections. Larger banks and more interconnected banks pose larger risks on the system for any given individual probabilities of failure. In addition, bailouts may give "too-manyto-fail" (TMTF) incentives for banks to engage in herding behavior to increase their chances of future bailouts, also increasing systemic risk. Greater size, interconnectedness, and correlated risks may all increase the likelihood of contagious runs of other institutions, increasing systemic risk further (e.g., Goldstein and Pauzner, 2004; Acharya and Yorulmazer, 2008; Bebchuk and Goldstein, 2011).

It is fundamentally an empirical question as to whether bailouts tend to reduce or increase systemic risk. Examining this question is challenging for several reasons, which we address in our analysis. First, there is no consensus on how to measure the risk of the financial system, despite a number of studies that compare measures or run "horse races" among them (e.g., Bisias, Flood, Lo, and Valavanis, 2012; Benoit, Colletaz, Hurlin, and Perignon, 2013; Sedunov, 2016; Zhang, Vallascas, Keasey, and Cai, forthcoming). The different measures of systemic risk used in the literature may be measuring different aspects of the risk of the financial system. We deal with this issue by using a number of different recently developed measures of individual banks' contributions to systemic risk and find consistent results.Accordingly, we formulate and test hypotheses about the effects of bailouts on systemic risk, focusing on two measures: the normalized conditional capital shortfall measure of systemic risk, Normalized SRISK (NSRISK), and Systemic Expected Shortfall (SES), described in more detail in Section 5.2. Our results are also robust to using other systemic risk measures. Second, the counterfactual of what the condition of the bailed-out banks would have been cannot be observed in the absence of bailouts because bailouts actually did occur. We attack this problem by comparing the post-bailout contributions to systemic risk of banks that received TARP bailouts relative to banks that were not bailed out. Third, bailed-out banks may differ from other banks in important ways other than their receipt of bailouts. We confront this issue by collecting information on the status of the banks' TARP applications to account for the selection of bailed-out banks. We also control econometrically for many differences across the banks in the regression analysis and by using instrumental variable analysis, Heckman selection model, propensity score matched analysis, and a placebo experiment. Fourth, it is difficult to disentangle the effects of bailouts from those of other government programs and market events occurring around the same time. We tackle this issue by including controls for other government programs, local market conditions, and time fixed effects.

To be more specific, we apply difference-in-difference (DID) regression models to publicly listed commercial banks and bank holding companies (BHCs) in the U.S. over 2005:Q1-2012:Q4 using NSRISK 
and SES as the key dependent variables, controlling for a number of factors that also affect systemic risk as well as time fixed effects. We are restricted to publicly-listed banking organizations because market values are required to calculate the measures of contributions to systemic risk. Fortunately, virtually all of the U.S. banking organizations with significant systemic footprints are publicly traded. Following Duchin and Sosyura (2014), we collect information on the status of the public banks' TARP applications to discern both banks' decisions to apply for TARP and regulators' decisions to grant funds. This enables us to account for the selection of bailed-out banks and analyze the systemic risk implications for these banks.

Our main results are robust to a number of different specifications. We show that our results are robust to an instrumental variable analysis, a Heckman (1979) self-selection model, and a propensity score matched analysis. In addition, we conduct a placebo experiment to help rule out the possibility that alternative forces drive our results. We try controlling for systematic risk, using an alternative measure of TARP, alternative proxies of systemic risk, and several alternative econometric models, including controlling for systematic risk, and find that our main results continue to hold. In addition, we test for which bank sizes and types and economic environments TARP was most effective. We find that reductions in contributions to systemic risk appear to be driven primarily by TARP banks that were larger, safer, and in locations with better economic conditions ex ante. As noted above, this has implications for which banks might be the best targets if future bailouts are considered. We also examine dynamics and find that bailout effects are relatively short-lived, cover the heart of the financial crisis, and may be reversed in the long run. Finally, we find that the primary channel through which TARP affected systemic risk is the capital cushion channel, which reduces leverage risk. This may have policy conclusions for the form that future bailouts might take and any other accompanying policy measures that might be helpful.

The remainder of the paper is organized as follows. Section 2 reviews the related empirical literature. Section 3 develops the hypotheses. In Section 4, we detail the econometric framework, and in Section 5, we discuss the data. Section 6 presents the main empirical results and a few robustness checks, and Section 7 shows additional robustness tests and subsample analyses. Section 8 draws conclusions and gives policy implications. Appendix X presents an overview of the TARP program and Appendix Y provides additional robustness analyses.

\section{Relation to Existing Empirical Literature}

As noted above, some empirical studies assess the effects of bailouts on components of individual bank risk, rather than their full contributions to systemic risk. In contrast, our paper is the first to directly address the effects of bailouts on systemic risk. 
Starting with the TARP studies, several researchers investigate the effects of these bailouts on the risks of the loans issued, with mixed results. Duchin and Sosyura (2014) use a sample of 529 publicly traded financial firms, which tend to be the largest firms, and find that TARP banks approve riskier loans. Black and Hazelwood (2013) analyze risk-taking using 81 banks from the Survey of Terms of Bank Lending (STBL) from 2007-2010 and find higher loan risk for large banks and lower loan risk for small banks. Berger, Makaew, and Roman (2016) study the effects of the TARP on loan contract terms and find that TARP generally led to more favorable terms of credit for both low-risk and high-risk customers, but the improvements were greater for high-risk borrowers, consistent with an increase in the exploitation of moral hazard incentives.

Others examine whether TARP bailouts decrease or increase their quantities of credit, which also affect portfolio risk, and find mixed results as well. Li (2013) and Puddu and Walchli (2013) find that TARP banks expanded their credit supply. Black and Hazelwood (2013) find mixed results and Bassett and Demiralp (2014) and Duchin and Sosyura (2014) do not find any evidence of a change in credit supply.

${ }^{2,3}$ Berger, Makaew, and Roman (2016) study the effects of the TARP on contract terms for business loans and find that TARP generally led to more favorable terms of credit for a broad spectrum of business borrowers, consistent with an increase in credit supply at the intensive margin.

Two papers focus on bailouts in Germany and look at bank risk measures z-score and riskweighted assets ratio and document opposing results. Dam and Koetter (2012) use a bailout probability measure and show that a higher probability of being bailed out increases German banks' risk-taking significantly. In contrast, Berger, Bouwman, Kick, and Schaeck (2016), find that capital support for banks is associated with significant reductions in risk-taking.

\section{Hypothesis Development}

We describe channels through which bailouts may reduce contributions to systemic risks, others through which bailouts may increase these contributions, and still others with ambiguous systemic risk

\footnotetext{
${ }^{2}$ Chang, Contessi, and Francis (2014) find that banks that received TARP funds maintained lower cash-to-assets ratios (and thus lower excess reserves ratios), consistent with the view that the TARP capital injection possibly resulted in more lending for TARP beneficiaries.

${ }^{3}$ For completeness, we note that other TARP studies focus on determinants of TARP bailouts entry and exit decisions (e.g., Bayazitova and Shivdasani, 2012; Duchin and Sosyura, 2012; Wilson and Wu, 2012; Cornett, Li, and Tehranian, 2013; Li, 2013; Duchin and Sosyura, 2014). Other related literature looks at the effects on bailout banks' and traded borrowers' valuations (e.g., Veronesi and Zingales, 2010; Kim and Stock, 2012, Liu, Kolari, Tippens, and Fraser, 2013; Norden, Roosenboom, and Wang, 2013; Ng, Vasvari, and Wittenberg-Moerman, 2013; Lin, Liu and Srinivasan, 2014; Zanzalari, 2014) and effects of bailouts in the U.S. and other countries on bank competition (e.g., e.g., Cordella and Yyati, 2003; Gropp, Hakenes, and Schnabel, 2011; Berger and Roman, 2015; Koetter and Noth, 2015; Calderon and Schaeck, forthcoming).
} 
implications, and develop hypotheses from these channels. Some of the channels are used in the literature to motivate changes in competition (Berger and Roman, 2015); local market economic conditions, lending, and off-balance sheet guarantees (Berger and Roman, forthcoming); and changes in loan contract terms (Berger, Makaew, and Roman, 2016); but they apply here as well because they may affect the banks' contributions to systemic risk in a number of ways. We also add several channels that are not used in the literature. We assume for the purposes of the analysis that the bailouts take the form of preferred equity injections as occurred in TARP, but channels for other bailout methods should generally be similar. For simplicity, we also abstract from the effects on systemic risk of other policies that might accompany bailouts, such as restrictions on common equity dividends or buybacks, stricter regulation or supervision of portfolio risk, imposition of limits on executive compensation, and/or tougher constraints on bank mergers and acquisitions (M\&As).

We group the channels into those that affect bailed-out banks' contributions to systemic risk by 1) decreasing or increasing leverage risk, 2) decreasing or increasing portfolio risk, and 3) increasing systemic importance. These channels are illustrated in Figure 1 and described in the next three subsections. Each channel is briefly described, and the direction of its effect on the bailed-out banks' contributions to systemic risk is indicated in bold in parentheses. In most cases, the channels appearing next to each other in Figure 1 and described consecutively below are opposites of one another with contrary systemic risk predictions, and only one of each pair can hold for a given bank at a given time. ${ }^{4}$

\subsection{Channels Affecting Contributions to Systemic Risk through Changing Individual Bank Leverage Risk}

- Capital Cushion Channel - Injecting preferred equity provides a greater cushion to absorb losses and reduce probabilities of financial distress and failure of the bailed-out banks. The injections may raise the values of bailed-out banks' common equity shares because of this safety, particularly during a crisis, making it easier to raise additional equity and reduce the likelihood of runs or panic selling of the common equity. ( $\downarrow$ contribution to systemic risk)

- Capital Priority Channel - The injected preferred equity has priority over common equity, which may amplify the losses of common equity holders in the event of failure, resulting in falls in the values of common equity, increasing the difficulty of raising equity, and raising the probability of runs and panic selling of the common equity. ( $\uparrow$ contribution to systemic risk)

\subsection{Channels Affecting Contributions to Systemic Risk through Changing Individual Bank Portfolio Risk}

\footnotetext{
${ }^{4}$ Specifically, the following pairs of channels are opposites: capital cushion and capital priority; decreased and increased moral hazard; charter value / quiet life and predation; stigma and safety; cost disadvantage and cost advantage; and increased or decreased market power.
} 
- Decreased Moral Hazard Channel - Higher preferred equity capital may reduce moral hazard incentives to take excessive risks that are engendered by deposit insurance and other aspects of the government safety net for banks (e.g., Kashyap, Rajan, and Stein, 2008; Acharya, Mehran, and Thakor, 2011; Admati, DeMarzo, Hellwig, and Pfleiderer, 2011; Calomiris and Herring, 2011; Hart and Zingales, 2011; Berger and Bouwman, 2013). Portfolio risk may also be reduced because of extra explicit or implicit government restrictions on these institutions, such as limits on executive compensation or additional portfolio scrutiny. ( $\downarrow$ contribution to systemic risk)

- Increased Moral Hazard Channel - Bailed-out banks may have increased moral hazard incentives to take additional portfolio risks because of a perceived increased probability of future bailouts (e.g., Acharya and Yorulmazer, 2007; Kashyap, Rajan, and Stein, 2008; Black and Hazelwood, 2013; Li, 2013; Duchin and Sosyura, 2014). The higher capital resulting from the injection of preferred equity may also encourage additional portfolio risk to offset any reduction in leverage risk from the bailouts (e.g., Koehn and Santomero, 1980; Kim and Santomero, 1988; Besanko and Kanatas, 1996; Calem and Rob, 1999). ( $\uparrow$ contribution to systemic risk)

- Charter Value / Quiet Life Channel - To the extent that the extra capital cushion from the preferred equity injection increases the value of common equity and reduces leverage risk, it may increase charter value and/or allow for a "quiet life," decreasing incentives for aggressive behavior and risk-taking, resulting in reduced portfolio risk (e.g., Hicks, 1935; Keeley, 1990; Cordella and Yeyati, 2003). ( $\downarrow$ contribution to systemic risk)

- Predation Channel - Bailed-out banks may use the extra capital to act aggressively in the market and increase their supply of risky credit, raising their portfolio risk (e.g., Telser, 1966; Fudenberg and Tirole, 1986). ( $\uparrow$ contribution to systemic risk)

- Stigma Channel - Bailed-out banks may be perceived as riskier due to the bailouts (e.g., Hoshi and Kashyap, 2010). Customers may demand less credit from recipient banks which are perceived as more likely to fail or become financially distressed. Creditors may supply less funds and/or charge higher rates because these banks are less likely to repay. Thus, both demand for and supply of credit may decline, reducing portfolio risk. ( $\downarrow$ contribution to systemic risk)

- Safety Channel - Bailed-out banks may be perceived as safer due to the bailout and/or the selection criteria which targeted "healthy, viable institutions." Customers may demand more risky credit from these banks because they are believed to be less likely to fail or become financially distressed. Also, creditors may supply more funds and/or charge lower rates because these banks are more likely to pay back. Thus, both demand for and supply of credit may be increased, increasing portfolio risk. ( $\uparrow$ contribution to systemic risk)

- Cost Disadvantage Channel - The preferred equity funds may be more expensive at the margin 
than other funds sources. Bailed-out banks decrease the supply of risky credit because costs of funds are higher, reducing portfolio risk. ( $\downarrow$ contribution to systemic risk)

- Cost Advantage Channel - The preferred equity funds may be cheaper at the margin than other funds sources. Bailed-out banks increase the supply of risky credit because costs of funds are lower, increasing portfolio risk. ( $\uparrow$ contribution to systemic risk)

- Increased or Decreased Market Power Channels - Bailouts may either increase or decrease the market power of the bailed-out banks and their rivals, depending on which of the eight other channels that affect portfolio risk are dominant (as discussed in Berger and Roman, 2015; Koetter and Noth, 2015). Changes in in market power in both directions have ambiguous effects on individual bank portfolio risk because they may result in increases or decreases in the credit supplied, depending in part on the proportions of relationship borrowers versus transactional borrowers to which the banks lend. An increase in market power may increase credit to relationship borrowers because market power helps banks enforce implicit contracts with relationship borrowers that result in greater credit availability (e.g., Petersen and Rajan, 1995). In contrast, an increase in market power may raise the price and decrease the supply of credit to transactional borrowers under the structure-conduct-performance hypothesis (e.g., Bain, 1959). These effects are reversed if market power is decreased. Thus, portfolio risk may either increase or decrease from changes in market power. (? contribution to systemic risk)

\subsection{Channels Affecting Contributions to Systemic Risk through Increasing Bank Systemic Importance}

- Too-Big-To-Fail Channel (Size) - Bailouts may encourage banks to become larger to increase the probabilities of future bailouts because of heightened perceptions of too-big-to-fail (TBTF) protections. Larger banks tend to pose greater risks on the system, independent of any changes in their individual bank risks, at least in part because large bank failures or financial distress have outsized effects on public confidence in the financial system. ( $\uparrow$ contribution to systemic risk)

- Too-Interconnected-To-Fail Channel (Interconnectedness) - Bailouts may encourage banks to become more interconnected - i.e., enter into more contracts (e.g., loans, derivatives) with other banks to increase the probabilities of future bailouts because of increased perceptions of toointerconnected-to-fail (TITF) protections. More interconnected banks pose greater risks on the system for any given individual bank risks. ( $\uparrow$ contribution to systemic risk)

- Too-Many-To-Fail Channel (Herding) - Bailouts may encourage banks to engage in herding behavior - such as engaging in similar investments or off-balance sheet activities. This increases the probabilities of financial distress in the same states of the world in which others are distressed. They may do so to increase their chances of future bailouts because of heightened perceptions of 
too-many-to-fail (TMTF) protections that many banks in distress would be bailed out in the event of systemic problems (e.g., Acharya and Yorulmazer, 2007, 2008; Brown and Dinc, 2011). ${ }^{5}$ Banks that herd pose greater risks on the system, independent of any changes in their individual bank risks. ( $\uparrow$ contribution to systemic risk)

\subsection{Hypotheses Derived from the Channels}

The above channels lead us to the following set of opposing hypotheses:

\section{H1: Bailouts reduce the contributions to systemic risk of recipient banks, ceteris paribus.}

\section{H2: Bailouts increase the contributions to systemic risk of recipient banks, ceteris paribus.}

\section{Econometric Framework}

We test Hypotheses $\mathrm{H} 1$ and $\mathrm{H} 2$ using data on the U.S. TARP bailouts. The hypotheses are not mutually exclusive and each of them may apply to different sets of TARP banks. Our empirical analysis tests which of these hypotheses empirically dominates overall and for specific groups of banks.

We use a difference-in-difference (DID) methodology. DID estimators are commonly used in the program evaluation literature (e.g., Meyer, 1995) to compare a treatment group to a control group both before and after treatment, and have been employed in the TARP literature (e.g., Duchin and Sosyura, 2014; Berger and Roman, 2015, forthcoming; Berger, Makaew, and Roman, 2016) and in other banking literature (e.g., Beck, Levine, and Levkov, 2010; Schaeck, Cihak, Maehler, and Stolz, 2012; Berger, Kick, and Schaeck, 2014). An advantage of this approach is that by analyzing the time difference of the group differences, we can account for omitted variables that affect treated and untreated groups alike. The regression model has the following form:

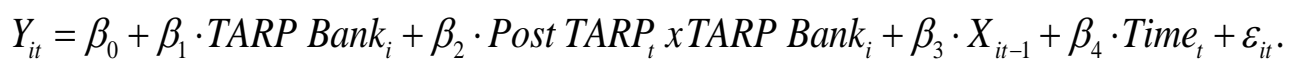

$Y_{i t}$ indicates contribution to systemic risk for bank $i$ at time $t\left(N S R I S K_{i, t}, S E S_{i, t}\right.$, and other measures described below). TARP Bank is a dummy for if a bank was approved for TARP and received TARP capital support, and zero if its application was not approved. Post TARP ${ }_{t}$ is a dummy equal to one in 2009:Q1-2012:Q4, the period after TARP started. Post TARP $x$ x TARP Bank $k_{i}$ is the DID term, capturing the effect of TARP after implementation. The term Post TARP $P_{t}$ is not included in the model by itself

\footnotetext{
${ }^{5}$ For example, banks may feel comfortable investing large portions of their portfolios in real estate loans, even if they know that these loans are risky and undiversified. They may do so because they know that many other banks are doing the same and so believe that they are more likely to be bailed out if the real estate market crashes.
} 
because it is subsumed by the time fixed effects. Negative coefficients on the DID terms would show reductions in contributions to systemic risk resulting from TARP, and vice-versa for positive coefficients. $X_{i t-I}$ are controls for the bank, market, and other government programs, Time $_{t}$ represents time fixed effects, and $\varepsilon_{i t}$ is an error term.

\section{Data and Sample}

\subsection{Data Sources}

We obtain TARP transactions data for the period October 2008 to December 2010 and the TARP recipients list from the Treasury's website. ${ }^{6}$ We match by name and location the institutions in the list with their corresponding RSSD9001 (Call Report ID) where available. The TARP report includes 572 bank holding companies (BHCs) and 87 commercial banks. ${ }^{7}$

We obtain bank data from quarterly Call Reports for the period 2005:Q1 to 2012:Q4. Given that the majority of the publicly listed TARP recipients are BHCs, we aggregate Call Report data at the holding company level if the BHC has more than one commercial bank owned. If the commercial bank is independent or in a one-bank BHC, we keep the commercial bank data. We exclude firm-quarter observations that do not refer to commercial banks (RSSD9331 different from 1), have missing or incomplete financial data for total assets or common equity, have missing or negative data for the income statement items such as interest expenses, personnel expenses, and non-interest expenses, or if the bank failed before 2009:Q1 (i.e., before observation of TARP effects). ${ }^{8}$ We normalize all financial variables using the seasonally-adjusted GDP deflator to be in real 2012:Q4 dollars. We merge these data with the New York Federal Reserve's list of publicly listed institutions and CRSP / COMPUSTAT data.

We complement the data with a further analysis of TARP applications. Following Duchin and Sosyura (2014), we identify TARP applicants and determine the status of each application for all publicly listed banks that could be merged to the Call Report and CRSP/COMPUSTAT. To achieve this, we read quarterly filings, annual reports, and proxy statements of all TARP-eligible public firms from 2008:Q4 to 2009:Q4. We also supplement these sources with searches of each firm's press releases and Google news for mentions of the firm and its TARP application status. We denote the application outcome of each of the TARP public banks in the sample as either received TARP funds, approved for TARP but declined the

\footnotetext{
${ }^{6}$ http://www.treasury.gov/initiatives/financial-stability/Pages/default.aspx

7 The TARP report also includes 48 thrifts and 2 S\&Ls. However, they do not have comparable Call Reports and their lending is very different (focus on residential mortgages), so we exclude them.

${ }^{8}$ To further address potential concerns of survivorship bias, we also rerun our results excluding banks that either fail or are acquired anytime during the sample period and find robust results.
} 
funds, TARP application was not approved, or bank did not apply for TARP (in cases where the bank filings specifically state that the bank did not apply for TARP or there is no mention in any of the media sources used of an application for TARP). As in Duchin and Sosyura (2014), we exclude from our analysis any banks that did not apply for TARP as it is not known whether the bank did not apply because it was discouraged or did not need TARP capital. We also exclude any banks that received preliminary approval, but declined the funds, as we are interested in how the capital injection itself changed the bank behavior after TARP was implemented. However, in a robustness test in Section 7.7, we include these latter banks and find consistent results.

We use data from several other sources for additional controls and instruments: List of Corrective Actions, U.S. Census Bureau's Population Distribution House of Representatives website, Missouri Census Data Center, and the Center for Responsible Politics website. The regressions lose one quarter of observations because of the use of lagged values for some of the exogenous variables. Our final regression sample contains 7,395 bank-quarter observations for 31 quarters.

\subsection{Main Dependent Variables}

For dependent variables, we consider two main measures of bank $i$ 's contribution to the systemic risk of the financial system at time $t: N S R I S K_{i, t}$ and $S E S_{i, t}$, which are discussed in detail here. Additional measures are discussed in Section 7.5.

\section{Expected Capital Shortfall (NSRISK)}

Acharya, Engle, and Richardson (2010) provide a measure, further refined by Brownlees and Engle (2015), for determining bank $i$ 's contribution to systemic risk at time $t$, called $S R I S K_{i, t}$. It is the expected capital shortfall of bank $i$ conditional on a crisis at time $t$. Specifically, SRISK $K_{i, t}$ measures how much capital bank $i$ would need in a crisis at time $t$ to maintain a given capital-to-assets ratio. $S R I S K_{i, t}$ is empirically measured market data on equities and balance sheet data on liabilities:

$$
\begin{aligned}
\text { SRISK }_{i, t} & =E_{t-1}\left(\text { Capital Shortfall }_{i} \mid \text { Crisis }\right) \\
& =E_{t-1}\left(k\left(\text { Debt }_{i}+\text { Equity }_{i}\right)-\text { Equity }_{i} \mid \text { Crisis }\right) \\
& =\text { kDebt }_{i, t-1}-(1-k)\left(1-\text { LRMES }_{i, t}\right) \text { Equity }_{i, t},
\end{aligned}
$$

where $k$ is a prudential level of book equity relative to assets. Following Brownlees and Engle (2015), we set $k$ equal to $8 \%$. LRMES as the decline in equity values conditional on a financial crisis.

$S R I S K_{i, t}$ is constructed from size, leverage, and exposure to market risk. Exposure to market risk 
is based on comovements of firm equity with broad equity measures. This is roughly analogous to a downside beta of the firm, and is correlated with the firm's CAPM beta. We normalize SRISK $K_{i, t}$ by bank market capitalization, and call this variable $\operatorname{NSRISK}_{i, t}$, which is the proportional capital increase that would be needed in a crisis. Without this normalization, the distribution would be highly skewed, so that its relation with the DID term, which is a dummy, would not be meaningful.

\section{Systemic Expected Shortfall (SES)}

Systemic Expected Shortfall $\left(S E S_{i, t}\right)$ measures the institution's "propensity to be undercapitalized when the system as a whole is undercapitalized" (Acharya, Pedersen, Philippon, and Richardson, forthcoming, p.1). A financial institution's $S E S_{i, t}$ is a linear combination of two key components: Marginal Expected Shortfall $\left(M E S_{i, t}\right)$ and Leverage $\left(L V G_{i, t}\right) . M E S_{i, t}$ estimates how individual institutions' stock returns react to those of the entire market (including nonfinancials) when aggregate returns are low. $M E S_{i, t}$ is calculated using the $5 \%$ of the worst days of market returns over the previous quarter of return data:

$$
M E S_{i, t}=\frac{1}{\# \text { days }} \sum_{\tau=1}^{\tau^{*}} R_{i, \tau}
$$

where $R_{i, \tau}$ represents the daily returns of the institution, and $\tau=1$ to $\tau^{*}$ represent days in which the market is in the tail of its return distribution.

$L V G_{i, t}$ is estimated using the traditional approximation using book liabilities and market equity:

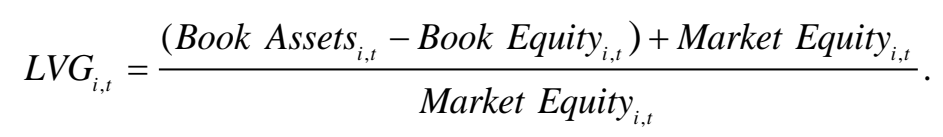

Acharya, Pedersen, Philippon, and Richardson (forthcoming) use these components in a cross-sectional regression methodology to estimate $S E S_{i, t}$. They regress the percentage stock returns of large U.S. institutions during the global financial crisis (which the authors call "realized $S E S$ ") on $M E S_{i, t}$ and $L V G_{i, t}$ from prior to the crisis. From the regression output, they estimate the following formula:

$$
S E S_{i, t}=0.15 M E S_{i, t-1}+0.04 L V G_{i, t-1}
$$

We use this equation to calculate fitted values for $S E S_{i, t}$ for every bank-quarter observation in our data.

\subsection{Main Independent Variables}

We use TARP Bank and the interaction term Post TARP $x$ TARP Bank as the key independent variables for our regression analysis. These are defined above in Section 4. 


\subsection{Control Variables}

We include a broad set of bank-related control variables to mitigate potential omitted variable problems. We control for proxies for CAMELS, the declared set of financial criteria used by regulators for evaluating banks, because these are widely perceived as good indicators of a bank's financial health (e.g., Duchin and Sosyura, 2014). Specifically, we control for Capital Adequacy to account for the extent to which a bank can absorb potential losses. This is constructed as the ratio of equity capital divided by gross total assets (GTA). ${ }^{9,10}$ We control for Asset Quality to account for the condition of a bank's portfolio, defined by the fraction of nonperforming loans to total loans. We control for Management Quality using a dummy taking a value of -1 if a bank had a corrective action by its primary federal regulator during the quarter, which may indicate increased risk. We control for Earnings, proxied by return on assets (ROA), the ratio of the annualized net income to GTA, because banks that are more profitable may be in better positions to reduce risk. We account for bank Liquidity, proxied by the ratio of cash over total deposits. Finally, Sensitivity to Market Risk is defined as the ratio of the absolute difference (gap) between short-term assets and shortterm liabilities to bank GTA.

To mitigate the concern that these CAMELS proxies may be the conduits through which TARP affects the recipient banks' contributions to systemic risk, we also rerun the regressions dropping these variables in the robustness tests in Section 7.4, and the results are consistent. Running our results with and without the CAMELS proxies may help mitigate the potential "bad controls problem" (inclusions as controls of variables that may potentially themselves be outcome variables, yielding estimation bias). Angrist and Pischke (2009), however, argue that there is a tradeoff between bad controls and omitted variable bias, so we show results with and without CAMELS to mitigate both types of concerns.

We control as well for other bank variables which may also affect their risks. We include Bank Size, the natural log of GTA; HHI Deposits, the Herfindahl-Hirschman Index determined using deposit data from the FDIC Summary of Deposits; Metropolitan, a dummy equal to one if 50\% or more of bank deposits are in metropolitan areas; and Number Branches / GTA, since bank size, competitive environment, and organizational complexity may be related to systemic risk. ${ }^{11}$

We also control for other government interventions. We use Discount Window and Term Auction

\footnotetext{
${ }^{9}$ Gross total assets (GTA) equals total assets plus the allowance for loan and lease losses and the allocated transfer risk reserve (a reserve for certain foreign loans). Total assets on Call Reports deduct these two reserves, which are held to cover potential credit losses. We add these reserves back to measure the full value of the assets financed.

${ }^{10}$ To avoid distortions for the Equity to GTA ratio, for all observations with equity less than $1 \%$ of GTA, we replace equity with $1 \%$ of GTA (as in Berger and Bouwman, 2009).

${ }^{11}$ The main results are robust to dropping these controls.
} 
Facility, dummies for if a bank used discount window and Term Auction Facility (TAF) funding, respectively, during the crisis. Berger, Black, Bouwman, and Dlugosz (2015) find that banks using these funds increased their lending significantly, with potential implications for their contributions to systemic risk. We also control for the U.S. stress tests, the Supervisory Capital Assessment Program (SCAP) and the Comprehensive Capital Analysis and Review (CCAR). These tests were applied to 19 banking organizations with assets exceeding $\$ 100$ billion to ensure these organizations had enough capital to withstand the recession and a hypothetical more adverse scenario over the rest of the financial crisis, and may have also acted to reduce the contributions to systemic risk of these institutions. ${ }^{12}$ We use SCAP/CCAR Participant, a dummy equal to one if the bank participated in the stress tests.

\section{Main Empirical Results}

\subsection{Summary Statistics}

Table 1 Panel A provides variable definitions and summary statistics. In terms of contribution to systemic risk measures, NSRISK has an average of 0.812 and SES averages 0.793. The TARP Bank variable shows that $86.8 \%$ of the banks in our sample received TARP money. This large proportion is because the systemic risk variables require use of only publicly traded banks, most of which received TARP funding.

Looking at the CAMELS proxies, we find that the average bank over our sample period has Capital Adequacy of 0.114, Asset Quality of 0.003, Management Quality of -0.005, Earnings of 0.010, Liquidity of 0.060, and Sensitivity to Market Risk of 0.138. These statistics suggest that on average over the sample period, banks were well capitalized and did not have many performance problems, although the means mask problems for individual banks at different points in time. We also find that $66.4 \%$ of the banks obtained Discount Window ( $D W$ ) funds, $28.0 \%$ obtained Term Auction Facility (TAF) funds, and $6.2 \%$ of the banks participated in the stress tests (SCAP/CCAR), the average Bank Size (logarithm of the GTA) is 14.892 (GTA of $\$ 3.38$ billion), average Bank Age is 102.862 years, 53.0\% of the banks acquired other institutions, and $93.5 \%$ of the institutions are BHCs. Finally, the means of HHI Deposits, Metropolitan, and Total Branches / GTA are 1398.830, 0.951, and 0.016, respectively.

\subsection{The Evolution of Average Contributions to Systemic Risk for TARP Banks and Non-TARP Banks}

To get a preliminary idea about whether TARP decreased or increased contributions to systemic risk, Figure 2 maps the evolution of the average contributions to systemic risk for TARP banks and non-TARP

\footnotetext{
${ }^{12}$ These 19 are Bank of America, Citigroup, Goldman Sachs, JP Morgan Chase, Morgan Stanley, Wells Fargo, Bank of NY Mellon, BB\&T, Fifth Third Bancorp, Keycorp, PNC Financial, Regions Financial, SunTrust Banks, US Bancorp, Ally Financial, American Express Company, Capital One Financial, Metlife, and State Street.
} 
banks over 2005:Q1 to 2012:Q4. Graph A displays the time-series of average NSRISK for both groups of banks, while Graph B shows the data for average SES.

Several observations are clear from these graphs. First, consistent with expectations, both TARP and non-TARP banks had increased average contributions to systemic risk during the crisis. Second, most relevant to evaluating our key question, after the TARP program started, the contributions of the nonTARP banks increased much more than those of the TARP banks. Third, by the end of the period, the lower average contributions of TARP banks vanish, with non-TARP banks actually having slightly lower average contributions. This preliminary evidence is consistent with the empirical dominance of Hypothesis $\mathrm{H} 1$ over $\mathrm{H} 2$, that bailouts reduce contributions to systemic risk, at least in the short run, but that the effects are not permanent and may be reversed in the long run. However, no control variables are included, so the ceteris paribus part of the hypotheses is not satisfied. A complete analysis requires the DID regression framework that controls for other factors, which we turn to next.

\subsection{Regression Analysis}

Table 2 shows the main DID regression estimation results for equation (1) and tests Hypotheses H1 and H2. Columns (1) and (2) present results using the main specification model. Columns (3) and (4) exclude the proxies for bank CAMELS to mitigate the possibility that TARP affects contribution to systemic risk through affecting the health of the recipient banks via these proxies. Columns (5) and (6) exclude controls other than proxies for bank CAMELS, and columns (7) and (8) exclude all controls.

The DID terms, Post TARP $x$ TARP Bank (shown in the shaded area), are negative and statistically significant in all eight cases, suggesting that TARP banks' capital injections are associated with decreases in contributions to systemic risk. These results are consistent with the statistical empirical dominance of Hypothesis H1 over Hypothesis H2.

The reductions in contributions to systemic risk are also economically significant, suggesting that Hypothesis $\mathrm{H} 1$ also economically dominates Hypothesis H2. Using the full set of control variables, the coefficient on Post TARP $x$ TARP Bank of -0.630 in the NSRISK equation in column (1) suggests that a change in TARP from 0 to 1 is related to a substantial reduction in NSRISK. The average recipient bank had a smaller capital shortfall (as a percent of total equity) of 63 percentage points, suggesting a $77.6 \%$ reduction in NSRISK relative to its sample mean. ${ }^{13}$ Similarly, we find the coefficient on Post TARP $x$ TARP Bank of -0.349 in the SES equation in column (2) suggests that a change in TARP from 0 to 1 means that the average recipient bank would see a reduction in its SES of 34.9 percentage points which is $43.0 \%$

\footnotetext{
${ }^{13} \mathrm{We}$ calculate this value as: $0.630 / 0.812=0.776$
} 
of the sample mean for SES. The other columns in Table 2 are comparable and demonstrate robustness, except that estimates are larger in absolute value terms when the CAMELS controls are removed.

\section{Additional Robustness Tests and Subsample Analyses}

\subsection{Endogeneity and Sample Selection Concerns}

The TARP program can be considered a quasi-natural experiment due to several uncertainties surrounding TARP. The proposal failed the first vote in Congress, and when it eventually passed the exact nature of the program's effects was not known - the public thought the program would be buying the toxic securities in the market instead of injecting equity into individual banks. This uncertainty was reflected in various media reports during the crisis. ${ }^{14}$ Thus, TARP was an unexpected shock to the financial system, suggesting that the TARP program may be considered to be reasonably exogenous.

However, a potential reverse causality concern of our TARP Bank variable could still arise and bias our findings. For example, as discussed above, TARP capital may have been more often provided to stronger banks. These stronger banks may have been more likely to reduce their contributions to systemic risk on their own, yielding a spurious relation. To mitigate these concerns, we perform several tests, including an instrumental variable analysis; a Heckman (1979) two-stage model; a propensity score matched analysis (PSM); and a placebo experiment.

\subsubsection{Instrumental Variable Analysis}

The related research discussed above finds that banks' political connections affected the bank's probability of receiving TARP funds. Accordingly, we follow this prior research (e.g., Li, 2013; Duchin and Sosyura, 2014; Berger and Roman, 2015, forthcoming; Berger, Roman, and Makaew, 2016) and use Subcommittees on Financial Institutions or Capital Markets as our instrument. This variable equals 1 if a bank is headquartered in the election district of a House member who served on the Financial Institutions Subcommittee or Capital Markets Subcommittee of the House Financial Services Committee in 2008 or

\footnotetext{
14 “'No' Votes Came from All Directions," June Kronholz, Sarah Lueck and Greg Hitt, Wall Street Journal, September 30, 2008: "House Republican opposition to the bill had been widely aired in recent days. It was objections raised by their leader, Ohio Rep. John Boehner that famously triggered the shouting match at a bipartisan White House meeting last week, killing the previous bailout proposal." "A majority of the Congressional Hispanic Caucus opposed the bill, with 14 against and eight in favor." http://www.wsj.com/articles/SB122273311165788291

"Bailout Plan Rejected, Markets Plunge, Forcing New Scramble to Solve Crisis," Sarah Lueck, Damian Paletta and Greg Hitt, Wall Street Journal, September 30, 2008: "The bill's failure puts the Treasury Department in a bind. Officials there considered the rescue plan as a last-ditch effort to come up with a systemic approach to tackling the financial crisis." http://www.wsj.com/articles/SB122270285663785991
} 
2009. ${ }^{15}$ As shown in Duchin and Sosyura (2014), these subcommittees played a direct role in the development of EESA and were charged with preparing voting recommendations for Congress on authorizing and expanding TARP. Members of these subcommittees were shown to arrange meetings between banks and the Treasury, write letters to regulators, and write provisions into EESA to help particular firms. This variable should be positively related to TARP decisions, and is almost surely exogenous to them because the distribution of committee assignments is determined by the House leadership, which is unlikely to be under the control of individual banks.

Because TARP Bank is binary, we employ a dummy endogenous variable model and follow a three-step approach as suggested in Wooldridge (2002, procedure 18.4.1) and Angrist and Pischke (2009). For the first stage, we use a probit model in which we regress TARP Bank on the political instrument and all bank controls from the main regression model. We then use the fitted value from the first stage as an instrument for the second stage. ${ }^{16}$ Thus, the second stage is a regression of the endogenous treatment variable TARP Bank on the predicted probability from the first stage and all bank controls ${ }^{17}$, and the third and final stage is a regression of the contribution to systemic risk on the predicted value from the second stage and all bank controls.

The IV regressions are reported in Table 3 Panels A and B. We report the first-stage results in Panel A. All specifications indicate that the instrument is positively related to TARP approval as hypothesized, and the first-stage $F$-tests suggest that the instrument is valid. The final-stage results for the IV specification are presented in Panel B, which indicate that the coefficients on the DID terms are negative and statistically significant, supporting our main findings. The IV estimates are larger in absolute value terms than the OLS estimates, consistent with other findings in the literature (e.g., Levitt, 1996; Berger and Bouwman, 2009). These results suggest that TARP banks' capital injections are associated

\footnotetext{
${ }^{15}$ We use the MABLE/Geocorr2k software on the Missouri Census Data Center website to associate banks with congressional districts by using the zip codes of their headquarters.

${ }^{16}$ Wooldridge (2002) procedure 18.4.1 is useful when the potentially endogenous variable $\mathrm{X}$ is binary, since the estimation is typically woefully inefficient when 2SLS is used directly for this case. Wooldridge's method is also suggested in Angrist and Pischke (2009), who argue that the conditional expectation function of the first 2SLS stage is probably nonlinear when an endogenous variable is dichotomous. Improved efficiency may be obtained by first regressing $X$ on the included instrument via probit or logit, predicting the probability $\hat{X}$, and using $\hat{X}$ as the single instrument (this method involves three steps and not just two). We follow this approach and use a probit for predicting the probability of TARP Bank and instrument our TARP Bank variable by the TARP dummy fitted value and Post TARP $x$ TARP Bank by the product of Post TARP and the TARP Bank dummy fitted value. As indicated in Wooldridge (2002, pp. 236-237), this method is not the same as the forbidden regression, as we use the obtained variable as an instrument, and not as a regressor.

${ }^{17}$ The second intermediate step allows the researcher to employ a non-linear probability for the assignment of the treatment, but does not impose a specific distributional assumption for the probability model.
} 
with decreases in contributions to systemic risk, consistent with our main findings.

\subsubsection{Heckman's (1979) Two-Stage Selection Model}

To address potential sample selection bias, we use Heckman's (1979) two-step procedure. This approach controls for selection bias introduced by bank and government choices about TARP by incorporating TARP decisions into the econometric estimation. In the first step, we use the same probit model from the IV estimation in Panel A. In the second stage, the contributions to systemic risk are the dependent variables, and we include the self-selection parameter (inverse Mills ratio) estimated from the first stage.

The second-stage results are reported in Table 3 Panel C. The coefficients on the inverse Mills ratio are generally not statistically significant, suggesting that sample selection bias is not a major issue. The DID terms for NSRISK and SES continue to suggest that TARP is associated with significant declines in contributions to systemic risk.

\subsubsection{Propensity Score Matching (PSM) Analysis}

To further address the concern of selection bias, we use a propensity score matching (PSM) analysis. We follow prior research (e.g., Black and Hazelwood, 2013; Duchin and Sosyura, 2014; Berger and Roman, 2015, forthcoming) and match each bank that applied for TARP but was not approved to a bank with similar characteristics that was approved and received TARP. This can help dispel the competing explanation that our results spuriously reflect different characteristics of recipients and non-recipients rather than the effects of TARP per se. We use a probit regression and estimate the propensity scores of the banks using their characteristics in 2008:Q3 (including all controls from the main specification), before the treatment started. TARP and non-TARP recipients are matched based on the absolute difference in propensity scores. Pairs with the smallest differences are considered matches and selected to be part of our analysis. We use a nearest-neighbor matching with $n=1$ without replacement, which matches each treatment unit to the nearest control unit, based on the closest propensity scores. ${ }^{18} \mathrm{We}$ rerun our main regressions using this matched sample in Table 4 . We find that the contribution to systemic risk results continue to hold in all specifications.

\subsubsection{Placebo Experiment}

It is also possible that alternative confounding forces that affect TARP and non-TARP banks differently may drive our main results. We therefore conduct a placebo experiment following Puddu and Walchli

\footnotetext{
${ }^{18}$ In unreported results, we also estimate the propensity scores using several other PSM techniques: nearest neighbor matching with replacement, nearest neighbor matching within 0.1 caliper, and Mahalanobis 1-to- 1 matching. The results are robust to all these alternative PSM methods.
} 
(2013) and Berger and Roman (2015, forthcoming). We fictionally assume that TARP participation took place earlier, while still distinguishing between banks that received TARP and those that were not approved according to the "true" TARP program. To mimic our main analysis, we use an eight-year period immediately preceding the TARP program from 2000-2007, and assume that the fictional Post TARP period begins five years before the actual program. Thus, we rerun the regressions using the placebo sample (2000-2007) and define Placebo Post TARP as a dummy equal to one in 2004-2007, the period after the fictional TARP program initiation. ${ }^{19}$ If our main results reflect the true program, we should not find negatively significant results for the DID terms.

The placebo experiment results are reported in Table 5. We find that the DID coefficients are either insignificant or go in the opposite direction of our main results. This suggests that banks that received TARP may have had high contributions to systemic risk at the beginning of the financial crisis, which corresponds to part of the fictional Post TARP period in the placebo experiments. Thus, it appears that our main results are not driven by alternative forces.

\subsection{Alternative Measure of TARP}

In Table 6, we test the robustness of our main results to the use of an alternative measure of TARP, $L n$ $(1+$ Bailout Amount). We find that the DID terms for both measures of systemic risk have negative and statistically significant coefficients, consistent with our main results.

\subsection{Alternative Measures of Contributions to Systemic Risk and Underlying Mechanisms}

In Table 7, we consider alternative measures of contributions to systemic risk. In columns (1)-(2), (6)-(7), (11)-(12), and (16)-(17), we present results using marginal expected shortfall (MES) and leverage (LVG) explained in Section 5.2. These variables are components of the SES variable used in the main analysis, but are also used by researchers as standalone systemic risk measures. The DID terms using both of measures have negative and statistically significant coefficients, consistent with decreases in the contribution to systemic risk and our main findings. However, when considering the relative importance of these two components of $S E S$, the $L V G$ measure appears to be by far the most important, explaining over $99 \%$ of the decrease in SES. ${ }^{20}$ This suggests that the reductions in contributions to systemic risk were primarily through the capital cushion channel in which the extra preferred equity provides a greater cushion

\footnotetext{
${ }^{19}$ In these regressions, we include all controls as in our main analysis, except that we are not able to include Management Quality because of data limitations on enforcement actions (only available from 2005 onwards).

${ }^{20}$ Under equation (5), SES $=0.15 M E S+0.04 L V G$, so that the change in SES due to TARP is given by 0.15 times the change in $M E S$ due to TARP plus 0.04 times the change in $L V G$ due to TARP. Plugging in the DID coefficients, $\triangle S E S=0.15 *-0.002+0.04 *-8.901=0.0003+0.35604=0.35634$. Thus, the part of the change in SES due to the change in $L V G$ represents 0.35604 / 0.35634 , or over $99 \%$ of the change in SES.
} 
to absorb losses and raises the market values of common equity shares.

In columns (3), (8), (13), and (18), we present results for Adrian and Brunnermeier's (forthcoming) $\triangle C o V A R .{ }^{21}$ Columns (5)-(6), (9)-(10), (15)-(16), and (19)-(20) present results for Systemic Factor2 and Systemic Factor3, computed using factor analysis based on our two main measures, NSRISK and SES, and on the three measures NSRISK, SES, and $\triangle C o V A R$, respectively. ${ }^{22}$ Results generally show a decrease in systemic risk for all of these measures, consistent with our main findings, and all measures of systemic risk but $\triangle C O V A R$ are robust to removing some of the controls.

\subsection{Alternative Econometric Models}

To help alleviate the concern that omitted unobserved bank-specific or state-specific determinants, respectively, might explain our results, we also test robustness using specifications with bank and time fixed effects in Table 8 Panel A and state and time fixed effects in Table 8 Panel B. We also present models with time fixed effects and standard errors clustered at the bank-time level in Table 8 Panel C, and with time fixed effects and standard errors clustered at the state-time level in Table 8 Panel D. In Table 8 Panel E, we present models with bank and time fixed effects standard errors clustered at the bank-time level. In Table 8 Panel F, we present models with state and time fixed effects standard errors clustered at the statetime level. In all specifications, we continue to find support for our main results.

\subsection{Additional Robustness Tests}

We next re-estimate the results controlling for systematic risk, which differs from systemic risk. A bank's contribution to systemic risk refers to its effects on the risk of financial system collapse. In contrast, a bank's systematic risk measures the part of its market risk that cannot be diversified in the stock market, and will not necessarily spill over to other financial institutions. As discussed above, the extant TARP literature focuses on components of individual bank risk. Some of these components affect systematic risk, some affect systemic risk, and some affect both. This is an important robustness test because it allows us to determine whether TARP affects the part of systemic risk that is unrelated to systematic risk. We

\footnotetext{
${ }^{21} \Delta \mathrm{CoVaR}$ is a measure of contribution to systemic risk as derived in Adrian and Brunnermeier (2016) and estimates the contribution of a single institution to the overall losses suffered by the financial system, given a crisis event. The $\mathrm{CoVaR}$ methodology uses quantile regressions to examine left-tail outcomes. Formally, an institution $j$ 's contribution to the financial system is given by the difference between the value at risk $(\mathrm{VaR})$ of the financial system conditional on the institution being under distress and the $V a R$ of the financial system conditional on the institution being in its median (normal) state: $\triangle \operatorname{CoVaR}_{q}^{s j}=\operatorname{CoVaR}_{q}^{s \mid X^{j}=\operatorname{VaR}_{q}^{j}}-\operatorname{CoVaR}_{q}^{s \mid X^{j}=\operatorname{Median}^{j}}$, where $s$ denotes the financial system, $j$ denotes the institution, $q$ denotes a probability level corresponding to the left tail of the distribution of institution-level asset returns, and $X_{j}$ denotes the growth rate of the institution's market valued total assets.

${ }^{22}$ Factor analysis allows us to generate new systemic risk variables that are linear combinations of the original factors by synthesizing the most important systemic risk information.
} 
measure systematic risk by multiplying the institution's squared CAPM beta by the market's variance, and add it to the control variables. ${ }^{23}$

The estimation results controlling for systematic risk are shown in Table 9 Panel A. The coefficients on the DID term, Post TARP $x$ TARP Bank, are relatively unchanged from our main results. This result supports our main conclusion that TARP reduced systemic risk, and also suggests that TARP had the effect of reducing the part of systemic risk that is unrelated to systematic risk. This also supports our conclusion that the main effects of TARP on systemic risk are a result of reduced leverage, which is not a component of systematic risk. Finally, the coefficients on Systematic Risk are generally, but not always, positive and statistically significant. These results suggest that while systematic risk and systemic risk are positively related, they are measuring different dimensions of bank risk.

In Table 9 Panel $\mathrm{B}$, we re-estimate the results from a sample which excludes involuntary participants in the TARP program to mitigate the concern that they may be driving our results. These eight banks (Citigroup, JP Morgan, Wells Fargo, Morgan Stanley, Goldman Sachs, Bank of New York, Bank of America, State Street Bank) were required to participate in TARP at its inception. ${ }^{24}$ Our results are robust to excluding these participants.

In Table 9 Panel $\mathrm{C}$, re-estimate the results from a sample which excludes banks subject to the stress tests to rule out the possibility that our main results may be determined by this subsample. Our results are robust to excluding these banks.

While we are unable to account for every government action during the crisis, in Table 9 Panel D, we report estimates when controlling for additional government programs that may have affected banks during the crisis: TAGP (Federal Deposit Transaction Account Guarantee Program) and TDGP (Temporary Debt Guarantee Program) - two programs initiated by the Federal Deposit Insurance Corporation (FDIC) during the recent financial crisis to encourage liquidity in the interbank lending market; SBLF (Small Business Lending Fund), created as part of the 2010 Small Business Jobs Act and

\footnotetext{
${ }^{23}$ For calculating systematic risk, we use the CAPM market model $R_{i, t}=\alpha_{i}+\beta_{i} R_{m, t}+\varepsilon_{i, t}$, where $R_{i, t}$ is the return on the bank stock $i$ at time $t, \beta_{i}$ is the regression coefficient when the return on security $i$ is regressed against the return on the stock market, and $R_{m, t}$ is the return on the stock market proxied by the CRSP value-weighted market index. We estimate both the CAPM market model and the variance of stock market returns over 100-day rolling windows. We decompose a security's total risk into systematic or non-diversifiable) market risk and idiosyncratic or diversifiable, firm-specific risk components using the following: Total Risk = Systematic Risk + Idiosyncratic Risk, which is equivalent to $\operatorname{Var}\left(R_{i, t}\right)=\beta_{i}^{2} \operatorname{Var}\left(R_{m, t}\right)+\operatorname{Var}\left(\varepsilon_{i, t}\right)$. We focus on systematic risk, calculated using daily bank stock returns as: Systematic Risk $=\beta_{i}^{2} \operatorname{Var}\left(R_{m, t}\right)$.

${ }^{24}$ We exclude Merrill Lynch from the original nine involuntary recipients because it is not a bank.
} 
intended to provide low-cost funding so that banks could lend to their small business customers: and FHLB (Federal Home Loan Bank Membership) which served as reliable source of funding for banks to support mortgage lending during the crisis. Our results are robust to including these additional programs.

\subsection{Dynamics of the Effects of TARP on Systemic Risk}

In Table 10, we examine the dynamics of the effects of TARP on contributions to systemic risk. We replace our DID term, Post TARP ${ }_{t} \times$ TARP Bank, with a series of DID terms, interacting the TARP Bank with dummies for each of the years after the TARP was implemented $(2009,2010,2011$, and 2012) to trace out the timing of the effects of TARP. The results are very strong in the first year of the post-TARP period, 2009 , and then they fade away and eventually go in the opposite direction in the last year, 2012. These findings suggest that the systemic risk improvements are concentrated in the heart of the crisis, last somewhat afterwards, and are reversed by the end of the sample. This is consistent with the preliminary analysis shown earlier in Figure 2.

\subsection{Subsample Analyses}

We conduct several subsample analyses to see for which types of banks and under what local economic conditions TARP was most effective in reducing systemic risk.

\subsubsection{Effects by Bank Size Classes}

The TARP literature often finds different bank sizes exhibit different lending behavior after TARP capital injections (e.g., Black and Hazelwood, 2013; Li, 2013; Puddu and Walchli, 2013; Duchin and Sosyura, 2014), raising the question of different effects on systemic risk. Table 11 Panel A1 examines the effect of TARP on contributions to systemic risk for banks in different size classes: small TARP banks (GTA $\leq \$ 1$ billion), medium TARP banks ( $\$ 1$ billion $\leq$ GTA $<\$ 3$ billion), and large TARP banks (GTA $>\$ 3$ billion).

Our results suggest that the effects are concentrated in large and medium banks, particularly the large banks. The large and medium TARP banks significantly decreased their contribution to systemic risk, while there is no significant effect on the small TARP banks. The $t$-tests reported in Panel A2 show

that the differences among the effects on different size classes of TARP banks are all statistically significant, and suggest that the large banks decreased their contribution to systemic risk the most.

\subsubsection{Banks with Low and High Systemic Risk (2008:Q3)}

We investigate whether safer (low systemic risk) versus less safe (high systemic risk) banks ex-ante were affected differently by bailouts. Lower-risk banks may be better positioned and have greater flexibility to reduce their risks or have greater incentives to reduce their risks because they suffer less from moral hazard 
problems. Alternatively, riskier banks ex ante may have greater opportunities or incentives to reduce their contributions to systemic risk.

In Table 10 Panel B1, we group banks according to their ex-ante systemic risk contributions: systemic risk $\leq$ median versus systemic risk > median before the TARP program started (2008:Q3). We find that only banks with lower systemic risk ex ante reduced their contributions to systemic risk ex post, and the differences are statistically significant, as shown in Panel B2. ${ }^{25}$

\subsubsection{Banks with Low and High Book Capital Ratios (2008:Q3)}

We next test whether our results about the effects on banks with low and high ex ante risk are robust to using the banks' ex ante book capital ratios. In Table 10 Panel C1, we group banks according to whether they had low total equity to assets ratio (capital ratio $\leq$ median) or high capital (capital ratio > median) prior to TARP (2008:Q3). We find banks with high ex ante capitalization ratios reduced their contribution to systemic risk statistically significantly more than those with low capital, and the $t$-tests for the difference in coefficients reported in Panel C2 are statistically significant.

\subsubsection{Banks in States in Poor and Good Conditions (2008:Q3)}

In Table 10 Panel D1, we differentiate between TARP banks in states with poor and good economic conditions before the TARP program started, measured using the Philadelphia Federal Reserve Bank's Coincident Index. This index combines four economic indicators - nonfarm payroll employment, average hours worked in manufacturing, the unemployment rate, and wage and salary disbursements deflated by the consumer price index - into a single statistic. We differentiate between states with low indices before the TARP program started (Coincident Index 2008:Q3 $\leq$ median) and high ex ante indices (Coincident Index 2008:Q3 > median). We find that results are primarily due to TARP banks in the states with good economic conditions (high coincident indices), and the $t$-tests for the difference in coefficients between the groups reported in Panel D2 are statistically significant.

\section{Conclusions}

Are bank bailouts worthwhile? Many benefits and costs are analyzed in the literature, but none seem more important than whether bailouts rescue the financial system versus make it more unstable. The question of the impact of bailouts on overall financial stability has not been addressed in the empirical literature, likely because financial stability is so difficult to measure, because it is hard to observe the counterfactual of

${ }^{25}$ In Appendix Y, we also conduct tests for a number of other safety issues for banks: ability to repay TARP funds early, ability to pay TARP dividends, and ex-ante capital ratio, and our results are consistent. 
what the condition of the financial system would have been in the absence of bailouts, because bailed-out banks may differ from other banks in important ways other than the bailouts, and because so many other government programs and market events occur around the same time.

We make progress by studying how one important bailout, the U.S. TARP, affected the recipient banks' measured contributions to systemic risk, controlling as well as feasible for other factors. In doing so, we address the tension between opposing points of view on how bailouts affect systemic risk. Our difference-in-difference analysis suggests that TARP led to statistically and economically significant decreases in contributions to systemic risk, consistent with a stabilization of the financial system. This finding is robust to a battery of robustness checks. Furthermore, our study complements the existing empirical bailout literature and adds to the broad debate on the benefits and costs of bailouts.

It is also important to know the sets of banks for which bailouts are most and least effective in reducing contributions to systemic risk so that any potential future bailouts may be targeted appropriately. Our results suggest that the reductions in contributions to systemic risk appear to be driven primarily by larger banks, banks that were safer, and banks in states with better economic conditions ex ante. These results are consistent with the theoretical arguments in Choi (2014) that recapitalization of stronger rather than weaker banks could more effectively reduce systemic risk.

It is also valuable to learn the channels through which bailouts are most and least effective. As discussed above, bailouts may affect systemic risk through altering individual bank leverage risk, portfolio risk, or systemic importance. Information on the effective channels may help determine the form any future bailouts might take as well as any additional policies that might accompany bailouts, such as restrictions on common equity dividends or buybacks to restrict leverage risk, tighter supervision or regulation of portfolio risk or limits on executive compensation to offset increased moral hazard incentives, or stiffer requirements for M\&A approvals to offset too-big-to-fail incentives created by bailouts. We find that the primary channel through which TARP affected systemic risk was the capital cushion channel, which reduced bank leverage risk, while other channels appear to have much smaller influences. These results suggest that injections of preferred equity can be successful in lowering contributions to systemic risk, and that any additional policies to control portfolio risk and/or bank size may be less important.

Studying the dynamics of bailouts can also provide valuable insights. Policy makers may be most interested in reducing systemic risk during the most disruptive times of financial crises. Our dynamic analysis suggests that effects of TARP on reducing contributions to systemic risk occurred during the heart of the crisis and then faded, and were perhaps reversed a few years later. 
To conclude, from a policy standpoint, the results suggest that 1) bank bailouts can help stabilize the financial system, 2) bailouts may be most effective in this regard if they are targeted toward larger banks, safer banks, and banks in markets with better economic conditions, 3) bailouts may be most effective when the systemic problems are at their worst, and 4) one particular form of bailout, injections of preferred equity, appears to work successfully to reduce systemic risk through reduced leverage risk. These conclusions are only based on consideration of systemic risk, and any potential future bailout policies must also consider other goals. As a final caveat, these results are only from one bailout that used preferred equity injections, and the systemic risk effects of other types of bailouts studied elsewhere, such as blanket guarantees, extended liquidity support, and widespread nationalization of banks (e.g., Laeven and Valencia, 2008, 2010, 2012; Berger, Black, Bouwman, and Dlugosz, 2015; Calderon and Schaeck, forthcoming) may differ. We encourage future research on the systemic risk implications of these other bailout methods. 


\section{References}

Acharya, V., Yorulmazer, T., 2007. Too many to fail - An Analysis of Time-inconsistency in Bank Closure Policies. Journal of Financial Intermediation 16, 1-31.

Acharya, V., Yorulmazer, T., 2008. Cash-in-the-Market Pricing and Optimal Resolution of Bank Failures. Review of Financial Studies 21, 2705-2742.

Acharya, V., Engle, R., Richardson, M., 2012. Capital shortfall: A new approach to ranking and regulating systemic risks. The American Economic Review 102, 59-64.

Acharya, V., Pedersen, L. H., Philippon, T., Richardson, M., Forthcoming. Measuring systemic risk. Review of Financial Studies.

Allen, F., Gale, D., 2001. Financial Contagion, Journal of Political Economy, 108, 1-33.

Angrist, J. D., Pischke, J.S., 2009. Mostly Harmless Econometrics. Princeton University Press, Princeton, N.J.

Bain, J. S., 1959, Industrial Organization: A Treatise, New York, NY: John Wiley \& Sons.

Barofsky, N., 2011. CNBC Interview on "The Kudlow Report", February 2, 2011.

Barofsky, N., 2012. An Inside Account of How Washington Abandoned Main Street While Rescuing Wall Street, www.thedailybeast.com/articles/2012/07/24/neil-barofsky-s-bailout-why-tarp-failed.html

Bassett, W.F., Demiralp, S., 2014. Government Support of Banks and Bank Lending. Working Paper, Board of Governors of the Federal Reserve System.

Bayazitova, D., Shivdasani, A., 2012. Assessing TARP. Review of Financial Studies 25, 377-407.

Beck, T., Levine, R., Levkov, A., 2010. Big Bad Banks? The Winners and Losers from Bank Deregulation in the United States. Journal of Finance 65, 1637-67.

Benoit, S., Colletaz, G., Hurlin, C., Pérignon, C., 2013. A theoretical and empirical comparison of systemic risk measures. Working Paper, HEC Paris Research Paper No. FIN-2014-1030.

Berger, A. N., Black, L. K., Bouwman, C. H. S., Dlugosz, J. L., 2015. The Federal Reserve's Discount Window and TAF Programs: "Pushing on a String?." Working Paper, University of South Carolina.

Berger, A. N., Bouwman, C. H. S., 2009. Bank Liquidity Creation. Review of Financial Studies 22, 37793837.

Berger, A.N., Bouwman, C. H. S., 2013. How does capital affect bank performance during financial crises?. Journal of Financial Economics 109, 146-176.

Berger, A. N., Bouwman C. H. S., Kick T. K., Schaeck K., 2016. Bank Risk Taking and Liquidity Creation Following Regulatory Interventions and Capital Support. Journal of Financial Intermediation 26, 115-141.

Berger, A. N., El Ghoul, S., Guedhami, O., Roman, R. A. Forthcoming. Internationalization and Bank Risk. Management Science.

Berger, A. N., Imbierowicz, B., Rauch, C., 2016. The Roles of Corporate Governance in Bank Failures during the Recent Financial Crisis, Journal of Money, Credit, and Banking 48, 729-770.

Berger, A. N., Klapper, L., Turk-Ariss, R., 2009. Bank Competition and Financial Stability, Journal of Financial Services Research 35, 99-118.

Berger, A. N., Kick T. K., Schaeck K., 2014. Executive Board Composition and Bank Risk Taking. Journal of Corporate Finance 28, 48-65.

Berger, A. N., Makaew, T., Roman, R. A., 2016. Do Borrowers Benefit from Bank Bailouts during Financial Crises? The Effects of TARP on Loan Contract Terms, Working Paper, University of South Carolina.

Berger, A. N., Roman R. A., 2015. Did TARP Banks Get Competitive Advantages? Journal of Financial and Quantitative Analysis 50, 1199-1236.

Berger, A. N., Roman R. A., Forthcoming. Did Saving Wall Street Really Save the Main Street? The Real Effects of TARP on Local Business Conditions, Journal of Financial and Quantitative Analysis.

Bernanke, B. S., 2009. Fed Chief: Government Averted Risk of Great Depression Repeat. ABC News, July 22, 2009.

Bernanke, B. S., 2015. The Courage to Act: A Memoir of the Crisis and Its Aftermath. W.W. Norton \& 
Company, 1st Edition.

Besanko, D., Kanatas, G., 1996. The regulation of bank capital: Do capital standards promote bank safety? Journal of Financial Intermediation 5, 160-183.

Bisias, D., Flood, M., Lo, A. W., Valavanis, S., 2012. A Survey of Systemic Risk Analytics, Working Paper, US Department of Treasury, Office of Financial Research.

Black, L., Hazelwood, L., 2013. The Effect of TARP on Bank Risk-taking. Journal of Financial Stability 9, 790-803.

Boyd, J. H., De Nicolo G., 2005. The theory of bank risk taking revisited. Journal of Finance 60, 13291343.

Boyd, J. H., De Nicolo G., Jalal, A. M., 2006. Bank Risk Taking and Competition Revisited: New Theory and Evidence. IMF Working paper, WP/06/297.

Brownlees, C. T., Engle, R. F., 2015. Volatility, correlation, and tails for systemic risk measurement. Working paper, New York University.

Calderon C., Schaeck, K., forthcoming. Bank Bailouts, Competition, and the Disparate Effects for Borrower and Depositor Welfare. Journal of Financial and Quantitative Analysis.

Calem, P., Rob, R., 1999. The impact of capital-based regulation on bank risk-taking. Journal of Financial Intermediation 8, 317-352.

Calomiris, C. W., Khan, U., 2015. An Assessment of TARP Assistance to Financial Institutions. Journal of Economic Perspectives 29, 53-80.

Carletti E., Hartmann P., 2003. Competition and financial stability: what's special about banking? In: Mizen P(ed) Monetary history, exchange rates and financial markets: essays in honour of Charles Goodhart, vol.2. Edward Elgar, Cheltenham, UK.

Chang, S - H., Contessi, S., Francis, J. L., 2014. Understanding the Accumulation of Bank and Thrift Reserves during the US Financial Crisis. Journal of Economic Dynamics and Control, 43, 78-106.

Choi, D. B., 2014. Heterogeneity and stability: Bolster the strong, not the weak. Review of Financial Studies, 27, 1830-1867.

Clerk of the United States House of Representatives, 2008. Final vote results for roll call 674, http://clerk.house.gov/evs/2008/roll674.xml.

Cordella, T., Yeyati, E. L., 2003. Bank Bailouts: Moral Hazard versus Value Effect. Journal of Financial Intermediation 12, 300-330.

Cornett, M. M., Li, L., Tehranian, H., 2013. The Performance of Banks around the Receipt and Repayment of TARP Funds: Over-achievers versus Under-achievers, Journal of Banking \& Finance 37, 730746.

Dam, L., Koetter, M., 2012. Bank Bailouts and Moral Hazard: Empirical Evidence from Germany. Review of Financial Studies 25, 2343-2380.

Degryse, H., Ongena, S., 2005. Distance, Lending Relationships, and Competition. Journal of Finance 60, 231-266.

Degryse, H., Laeven, L., Ongena, S., 2009. The Impact of Organizational Structure and Lending Technology on Banking Competition. Review of Finance 13, 225-259.

Demsetz R., Saidenberg M. R., Strahan P. E., 1996. Banks with something to lose: the disciplinary role of franchise value. Fed Reserve Bank N Y Econ Policy Rev 2, 1-14.

Diamond, D. W., Rajan, R. G., 2005. Liquidity Shortages and Banking Crises, Journal of Finance 60, 61547.

Diamond, D. W., Rajan, R. G., 2009. Illiquidity and Interest Rate Policy. Mimeo, University of Chicago.

Duchin D., Sosyura D. 2012. The Politics of Government Investment. Journal of Financial Economics 106, 24-48.

Duchin R., Sosyura, D., 2014. Safer Ratios, Riskier Portfolios: Banks' Response to Government Aid. Journal of Financial Economics 113, 1-28.

Fahlenbrach, R., Prilmeier, R., Stulz, R. 2012. "This Time Is the Same: Using Bank Performance in 1998 to Explain Bank Performance during the Recent Financial Crisis," Journal of Finance 67, 2139- 
2185.

Farhi, E., Tirole, J., 2012. Collective Moral Hazard, Maturity Mismatch, and Systemic Bailouts. American Economic Review 102, 60-93.

Freixas, X., Parigi, B. M., Rochet, J.-C., 2000. Systemic Risk, Interbank Relations, and Liquidity Provision by the Central Bank. Journal of Money, Credit and Banking 32, 611-38.

Fudenberg, D., Tirole, J., 1986. A 'Signal-Jamming' Theory of Predation. Rand Journal of Economics 17, 366-376.

Gropp, R., Hakenes, H., Schnabel, I., 2011. Competition, Risk-Shifting, and Public Bail-Out Policies. Review of Financial Studies 24, 2084-120.

Hakenes, H., Schnabel, I., 2010. Banks without Parachutes: Competitive Effects of Government Bail-Out Policies. Journal of Financial Stability 6, 156-168.

Hicks, J., 1935. Annual Survey of Economic Theory: The Theory of Monopoly. Econometrica 3, 1-20.

Holmstrom, B., Tirole, J., 1997. Financial Intermediation, Loanable Funds, and the Real Sector. Quarterly Journal of Economics 112, 663-691.

Hoshi, T., Kashyap, A.,. 2010. Will the U.S. Bank Recapitalization Succeed? Eight Lessons from Japan. Journal of Financial Economics 97, 398-417.

Houston, J., James, C. and Marcus, D., 1997. Capital Market Frictions and the Role of Internal Capital Markets in Banking. Journal of Financial Economics 46, 135-164.

Kashyap, A.K., Rajan, R., Stein, J.C., 2008. Rethinking capital regulation. Kansas City Symposium on Financial Stability.

Keeley, M. C., 1990. Deposit Insurance, Risk, and Market Power in Banking. American Economic Review 80, 1183-1200.

Kim, D.H., Stock, D., 2012. Impact of the TARP financing choice on existing preferred stock. Journal of Corporate Finance 18, 1121-1142.

Kim, D., Santomero, A.M., 1988. Risk in banking and capital regulation. Journal of Finance, 43, 12191233.

Kindleberger, C.P., 1978. Manias, panics and crashes: A history of financial crises. Springer.

Koehn, M., Santomero, A.M., 1980. Regulation of bank capital and portfolio risk. Journal of Finance 35, 1235- 1250.

Koetter, M. and Noth, F., 2015. Bank Bailouts and Competition - Did TARP Distort Competition Among Sound Unsupported Banks?. Economic Inquiry 54, 994-1020.

Krugman, P., 2009. Averting the Worst. New York Times, August 9, 2009.

Laeven, L., Valencia, F., 2008. Systemic banking crises: A new database. International Monetary Fund Working Paper 08/224, Washington, D.C.

Laeven, L., Valencia, F., 2010. Resolution of banking crises: The good, the bad, and the ugly, International Monetary Fund Working Paper 10/146, Washington, D.C.

Laeven, L., Valencia, F., 2012. The use of blanket guarantees in banking crises. Journal of International Money and Finance 31, 1220-1248.

Levitt, S., 1996. The effect of prison population size on crime rates: Evidence from prison overcrowding litigation. Quarterly Journal of Economics 111, 319-351.

Li, L., 2013. TARP Funds Distribution and Bank Loan Supply, Journal of Banking and Finance 37: 47774792.

Lin, Y., Liu, X., Srinivasan, A., 2014. Unintended effects of the TARP program: Evidence from relationship borrowers of the TARP recipient banks. Working Paper, National University of Singapore.

Liu, W., Kolari, J. W., Tippens, T. K., Fraser, D. R., 2013. Did capital infusions enhance bank recovery from the great recession?. Journal of Banking \& Finance, 37, 5048-5061.

Martinez-Miera, D., Repullo, R., 2010, Does Competition Reduce the Risk of Bank Failure? Review of Financial Studies 23, 3638-3664.

Meyer, B. D., 1995. Natural and Quasi-Experiments in Economics. Journal of Business and Economic Statistics 13, 151-161. 
Ng, J., Vasvari, F. P., Wittenberg-Moerman, R., 2013. The Impact of TARP's Capital Purchase Program on the Stock Market Valuation of Participating Banks. Working Paper. University of Chicago.

Norden, L., Roosenboom, P., Wang, T., 2013. The Impact of Government Intervention in Banks on Corporate Borrowers' Stock Returns. Journal of Financial and Quantitative Analysis 48, 1635-1662.

Petersen, M. A., Rajan, R. G., 1995. The Effect of Credit Market Competition on Lending Relationships. Quarterly Journal of Economics, 110, 407-443.

Puddu, S., Wälchli, A., 2013. TARP Effect on Bank Lending Behaviour: Evidence from the Last Financial Crisis, Working Paper, Université de Neuchâtel.

Reinhart, C.M., Rogoff, K.S., 2009. This Time Is Different: Eight Centuries Of Financial Folly, Princeton University Press, Princeton.

Rogoff, K.S., 2010. How Effective was TARP, Really?. The Economist, October 8, 2010.

Schaeck, K., Cihak, M., Maehler, A. M., Stolz, S. M., 2012. Who Disciplines Bank Managers?, Review of Finance, 16:197-243.

Schaeck, K., Cihak, M., Wolfe, S., 2009. Are More Competitive Banking Systems More Stable? Journal of Money, Credit, and Banking 41, 711-734.

Sedunov, J. 2016. What is the Systemic Risk Exposure of Financial Institutions?, Journal of Financial Stability 24, 71-87.

Telser, L. G., 1966. Cutthroat Competition and the Long Purse. Journal of Law and Economics 9, 259-77.

Veronesi, P., Zingales L., 2010. Paulson's Gift, Journal of Financial Economics 97, 339-36.

Wilson, L., Wu, Y.W., 2012. Escaping TARP. Journal of Financial Stability 8, 32-42.

Wooldridge, J. M. 2002. Econometric Analysis of Cross Section and Panel Data. Cambridge, MA: MIT Press, 623-25.

Zanzalari, D., Does Bank Size Matter? Investor Reactions to TARP, 2014. Working Paper, Clemson University.

Zhang, Q., Vallascas, F., Keasey, K., Cai, C., Forthcoming. Are Market-Based Rankings of Global Systemically Important Financial Institutions Useful for Regulators?, Journal of Money, Credit, and Banking. 


\section{Figure 1: Channels for Contributions to Systemic Risk for Bailed-Out Banks}

This figure displays the channels through which the contributions to systemic risk of bailed-out banks may decrease, increase, or be ambiguous. We assume for the purpose of the analysis that the bailouts take the form of injections of preferred equity as occurred in the TARP bailouts, but channels for other bailout methods should generally be similar.

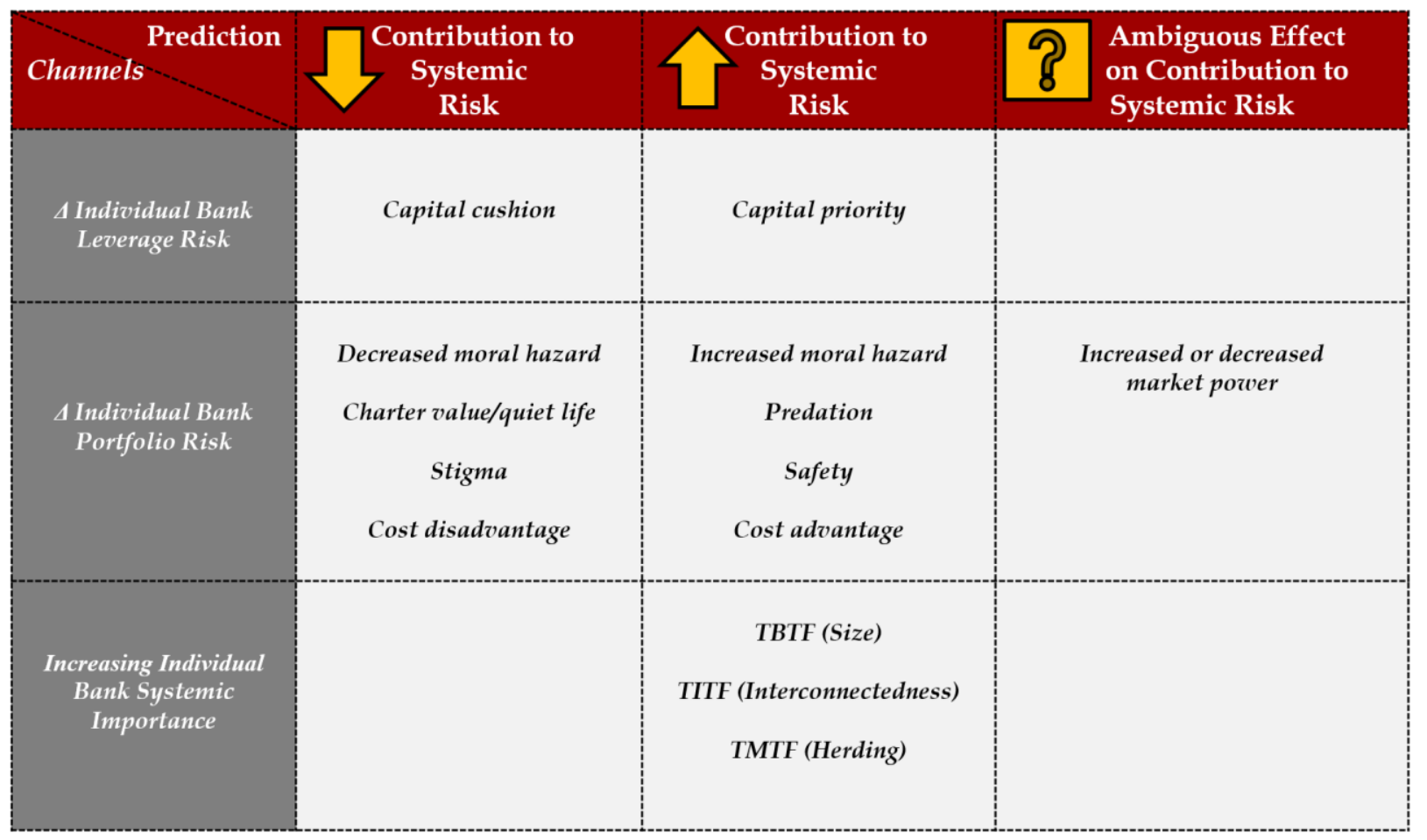


Figure 2: Average Contributions to Systemic Risk for TARP Banks and Non-TARP Banks over Time (2005:Q1-2012:Q4)

This figure maps measures of average contributions of systemic risk for TARP banks and non-TARP banks over 2005:Q1 to 2012:Q4 using average NSRISK in Panel A and average SES in Panel B.

Graph A: Average NSRISK for TARP Banks and Non-TARP Banks

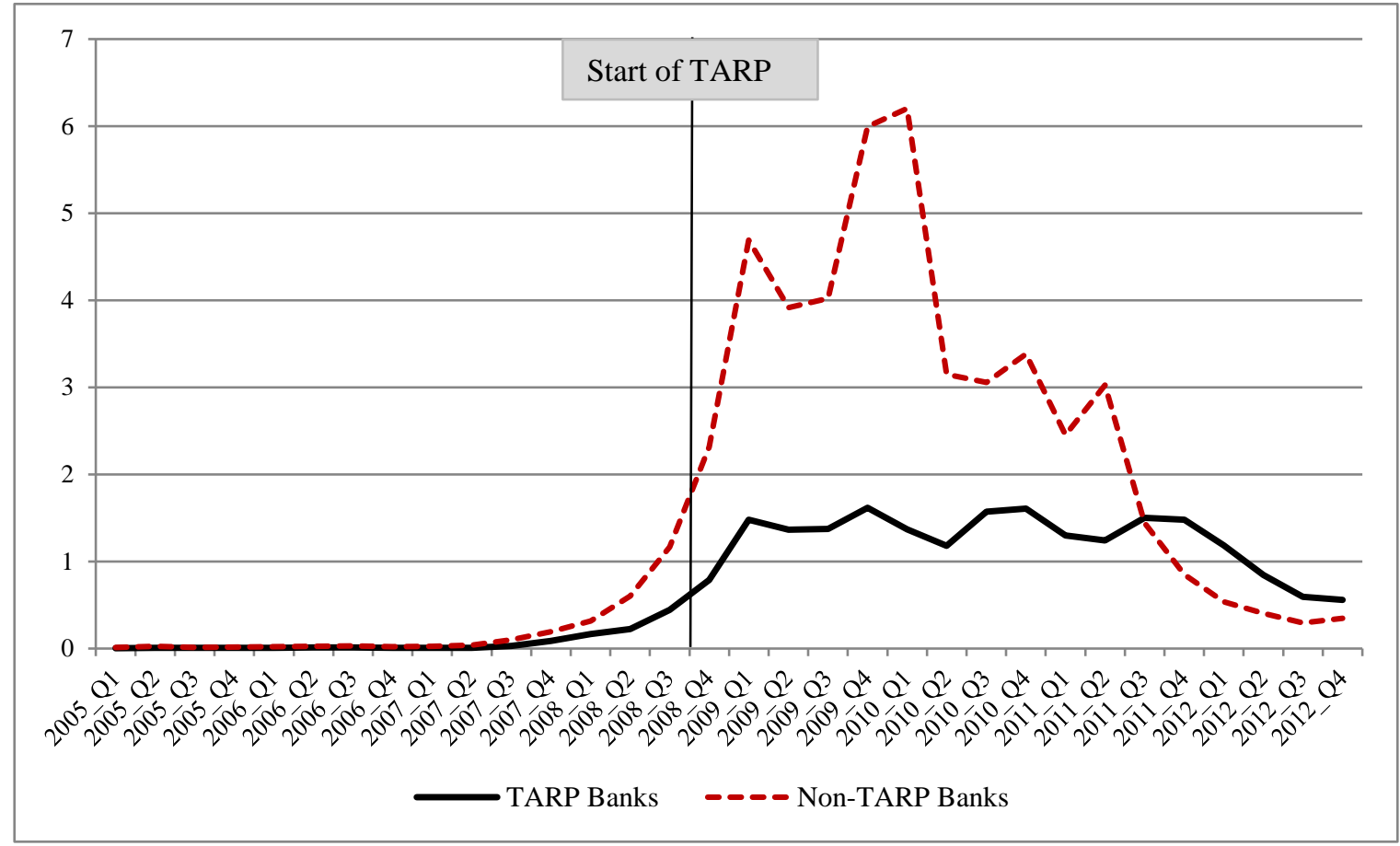

Graph B: Average SES for TARP Banks and Non-TARP Banks

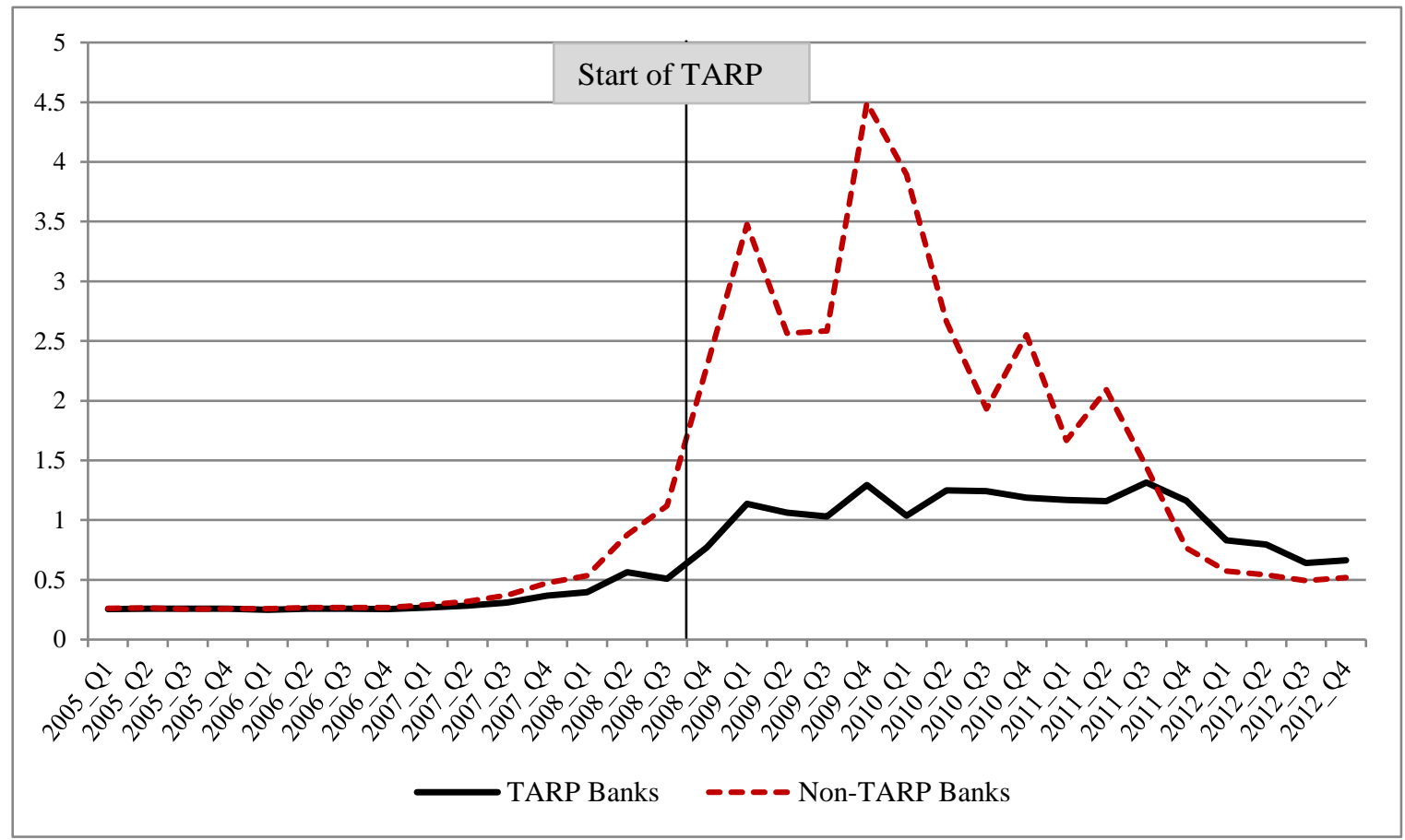


Table 1: Summary Statistics and Correlations (2005:Q1-2012:Q4)

Panel A reports variable definitions and summary statistics of the variables for the full sample. All variables using dollar amounts are expressed in real 2012:Q4 dollars using the implicit GDP price deflator. Panel B presents correlations for the key variables in our analysis.

\section{Panel A: Summary Statistics}

\begin{tabular}{|c|c|c|c|c|c|c|c|}
\hline Variable & Definition & mean & p50 & sd & p25 & p75 & $\mathbf{N}$ \\
\hline \multicolumn{8}{|l|}{ Systemic Risk Variables } \\
\hline NSRISK & $\begin{array}{l}\text { The conditional capital shortfall measure of systemic risk, developed by Acharya, Engle, and } \\
\text { Richardson (2010) and further refined by Brownlees and Engle (2015). It indicates the capital shortfall } \\
\text { of a bank conditional on a severe market decline, and is a function of its size, leverage and risk. The } \\
\text { exact construction is explained in detail in Section 5.2. }\end{array}$ & 0.812 & 0.085 & 2.209 & 0.000 & 0.674 & 7,395 \\
\hline SES & $\begin{array}{l}\text { The systemic expected shortfall measure developed by Acharya, Pedersen, Philippon, and Richardson } \\
\text { (forthcoming). It indicates the bank propensity to be undercapitalized when the system as a whole is } \\
\text { undercapitalized, which increases in its leverage, volatility, correlation, and tail dependence. The exact } \\
\text { construction of this variable is explained in detail in Section } 5.2 \text {. }\end{array}$ & 0.793 & 0.388 & 1.505 & 0.268 & 0.711 & 7,269 \\
\hline$M E S$ & $\begin{array}{l}\text { The marginal expected shortfall. It uses a simple non-parametric estimation and measures the average } \\
\text { return of financial institutions on days when the market as a whole is in the tail of its return distribution. } \\
\text { The exact construction of this variable is explained in detail in Section 5.2. }\end{array}$ & 0.042 & 0.037 & 0.023 & 0.023 & 0.052 & 7,280 \\
\hline$L V G$ & $\begin{array}{l}\text { Bank leverage estimated as the ratio of bank book assets minus bank book equity }+ \text { bank market equity, } \\
\text { all divided by market value of equity. }\end{array}$ & 19.989 & 9.998 & 37.323 & 7.039 & 17.938 & 7,384 \\
\hline \multicolumn{8}{|l|}{ TARP Variables } \\
\hline TARP Bank & $\begin{array}{l}\text { A dummy equal to one if a bank was approved for TARP and received TARP funds, and } 0 \text { if it applied } \\
\text { for TARP but was not approved. }\end{array}$ & 0.868 & 1.000 & 0.338 & 1.000 & 1.000 & 7,395 \\
\hline Post TARP & $\begin{array}{l}\text { A dummy equal to } 1 \text { in } 2009-2012 \text { and } 0 \text { in 2005-2008. Similar to Sosyura and Durchin (2014) but } \\
\text { using an extended time period. }\end{array}$ & 0.132 & 0.000 & 0.338 & 0.000 & 0.000 & 7,395 \\
\hline Ln $(1+$ Bailout Amount $)$ & $\begin{array}{l}\text { The natural logarithm of } 1 \text { plus the bank dollar bailout support; a larger value indicates a higher degree } \\
\text { of TARP support. }\end{array}$ & 0.498 & 0.000 & 0.500 & 0.000 & 1.000 & 7,395 \\
\hline \multicolumn{8}{|l|}{ Bank Control Variables } \\
\hline CAMELS Proxy: Capital Adequacy & $\begin{array}{l}\text { The bank capitalization ratio defined as equity capital divided by GTA. Capital adequacy refers to the } \\
\text { amount of a bank's capital relative to its assets. Broadly, this criterion evaluates the extent to which a } \\
\text { bank can absorb potential losses. }\end{array}$ & 0.114 & 0.109 & 0.031 & 0.097 & 0.126 & 7,395 \\
\hline CAMELS Proxy: Asset Quality & $\begin{array}{l}\text { The bank asset quality, where asset quality evaluates the overall condition of a bank's portfolio and is } \\
\text { typically evaluated by a fraction of nonperforming assets and assets in default. Noncurrent loans and } \\
\text { leases are loans that are past due for at least ninety days or are no longer accruing interest. Higher } \\
\text { proportion of nonperforming assets indicates lower asset quality. }\end{array}$ & & & & & & \\
\hline & & 0.003 & 0.000 & 0.008 & 0.000 & 0.002 & 7,395 \\
\hline $\begin{array}{l}\text { CAMELS Proxy: Management } \\
\text { Quality }\end{array}$ & $\begin{array}{l}\text { The bank management quality determined as the negative of the number of corrective actions that were } \\
\text { taken against bank executives by the corresponding banking regulator during the sample period 2005- } \\
2012 \text { (FED, FDIC, and OCC). }\end{array}$ & -0.005 & 0.000 & 0.081 & 0.000 & 0.000 & 7,395 \\
\hline
\end{tabular}




\begin{tabular}{|c|c|c|c|c|c|c|c|}
\hline Variable & Definition & mean & p50 & sd & p25 & p75 & $\mathbf{N}$ \\
\hline \multicolumn{8}{|l|}{ Bank Control Variables (cont.) } \\
\hline CAMELS Proxy: Earnings (ROA) & $\begin{array}{l}\text { The bank earnings or return on assets (ROA), measured as the ratio of the } \\
\text { annualized net income to GTA. }\end{array}$ & 0.010 & 0.016 & 0.043 & 0.006 & 0.029 & 7,395 \\
\hline CAMELS Proxy: Liquidity & The bank liquidity defined as cash divided by bank total deposits. & 0.060 & 0.038 & 0.070 & 0.027 & 0.065 & 7,395 \\
\hline CAMELS Proxy: Sensitivity to Market Risk & $\begin{array}{l}\text { The bank sensitivity to interest rate risk, defined as the ratio of the absolute } \\
\text { difference (gap) between short-term assets and short-term liabilities to GTA. }\end{array}$ & 0.138 & 0.114 & 0.108 & 0.055 & 0.197 & 7,395 \\
\hline Bank Size & The natural logarithm of bank GTA. & 14.892 & 14.468 & 1.676 & 13.775 & 15.593 & 7,395 \\
\hline Bank Age & Age in years since the institution was established. & 102.862 & 76.000 & 148.949 & 23.000 & 125.000 & 7,395 \\
\hline$M \& A$ & $\begin{array}{l}\text { A dummy variable that takes a value of } 1 \text { from the time that the bank acquired } \\
\text { another institution and } 0 \text { otherwise. }\end{array}$ & 0.530 & 1.000 & 0.499 & 0.000 & 1.000 & 7,395 \\
\hline BHC Indicator & $\begin{array}{l}\text { A dummy variable that takes a value of } 1 \text { if bank is a bank holding company } \\
\text { (BHC). }\end{array}$ & 0.935 & 1.000 & 0.247 & 1.000 & 1.000 & 7,395 \\
\hline Metropolitan & $\begin{array}{l}\text { A dummy variable that takes a value of } 1 \text { when the majority of bank deposits } \\
\text { (50\% or more) are in metropolitan areas and } 0 \text { otherwise. }\end{array}$ & 0.951 & 1.000 & 0.216 & 1.000 & 1.000 & 7,395 \\
\hline HHI Deposits & $\begin{array}{l}\text { A measure of bank concentration, measured by the Herfindahl-Hirschman } \\
\text { Deposits Index determined using the bank deposit data from the FDIC Summary } \\
\text { of Deposits. Higher values show greater market concentration. }\end{array}$ & 1398.830 & 1284.284 & 637.614 & 1051.993 & 1587.267 & 7,395 \\
\hline Total Branches/GTA & $\begin{array}{l}\text { A measure of organizational complexity defined as the ratio of the number of } \\
\text { branches over GTA multiplied by } 1000 \text {. }\end{array}$ & 0.016 & 0.015 & 0.008 & 0.009 & 0.021 & 7,395 \\
\hline \multicolumn{8}{|l|}{ Other Government Programs } \\
\hline Discount Window & $\begin{array}{l}\text { A dummy equal to one if a bank received Discount Window loans during the } \\
\text { crisis. }\end{array}$ & 0.664 & 1.000 & 0.472 & 0.000 & 1.000 & 7,395 \\
\hline Term Auction Facility & $\begin{array}{l}\text { A dummy equal to one if a bank received Term Auction Facility (TAF) funding } \\
\text { during the crisis. }\end{array}$ & 0.280 & 0.000 & 0.449 & 0.000 & 1.000 & 7,395 \\
\hline SCAP / CCAR Participant & $\begin{array}{l}\text { A dummy variable that takes a value of } 1 \text { if a bank participated in the SCAP / } \\
\text { CCAR Stress Tests. }\end{array}$ & 0.062 & 0.000 & 0.241 & 0.000 & 0.000 & 7,395 \\
\hline \multicolumn{8}{|l|}{ Instrumental Variable } \\
\hline $\begin{array}{l}\text { Subcommittees on Financial Institutions or } \\
\text { Capital Markets }\end{array}$ & $\begin{array}{l}\text { A dummy which takes a value of } 1 \text { if a firm is headquartered in a district of a } \\
\text { House member, who served on the Capital Markets Subcommittee or the } \\
\text { Financial Institutions Subcommittee of the House Financial Services Committee } \\
\text { in } 2008 \text { or } 2009 \text {. }\end{array}$ & 0.190 & 0.000 & 0.392 & 0.000 & 0.000 & 7,395 \\
\hline
\end{tabular}


Table 2: Effects of TARP on Systemic Risk: Main Results

This table reports estimates from difference-in-difference (DID) regression estimates for analyzing the impact of TARP on contributions to systemic risk. The measures of these contributions are the Expected Capital Shortfall (NSRISK) and the Systemic Expected Shortfall (SES). TARP Bank is a dummy equal to one if a bank was approved for TARP and received TARP funds, and 0 if it applied for TARP but was not approved, Post TARP is a dummy equal to one in 2009-2012, the period after TARP program initiation. Columns (1) and (2) present results using the main specification model. Columns (3) and (4) present models which exclude the proxies for bank CAMELS. Columns (5) and (6) present models which exclude controls other than proxies for bank CAMELS. Columns (7) and (8) present models which exclude all controls. All models include time fixed effects. The estimation results are for 2005-2012. All variables are defined in Table $1 . *, * *$, and $* * *$ denote significance at $10 \%, 5 \%$, and $1 \%$ level.

\begin{tabular}{|c|c|c|c|c|c|c|c|c|}
\hline \multirow[b]{2}{*}{ Dependent Variable: } & \multicolumn{2}{|c|}{$\begin{array}{c}\text { Main } \\
\text { Specification } \\
\end{array}$} & \multicolumn{2}{|c|}{$\begin{array}{c}\text { Excluding Proxies } \\
\text { for CAMELS }\end{array}$} & \multicolumn{2}{|c|}{$\begin{array}{l}\text { Excluding Controls } \\
\text { Other than CAMELS } \\
\end{array}$} & \multicolumn{2}{|c|}{$\begin{array}{l}\text { Excluding All } \\
\text { Bank Controls }\end{array}$} \\
\hline & NSRISK & $S E S$ & NSRISK & $S E S$ & NSRISK & $S E S$ & NSRISK & SES \\
\hline Independent Variables: & (1) & (2) & (3) & (4) & (5) & (6) & (7) & (8) \\
\hline TARP Bank & $\begin{array}{l}-0.099 * * \\
(-2.020)\end{array}$ & $\begin{array}{c}-0.102 * * * \\
(-2.748)\end{array}$ & $\begin{array}{c}-0.113^{* * *} \\
(-2.582)\end{array}$ & $\begin{array}{c}-0.113 * * * \\
(-3.060)\end{array}$ & $\begin{array}{l}-0.086^{* *} \\
(-2.055)\end{array}$ & $\begin{array}{c}-0.121 * * * \\
(-3.634)\end{array}$ & $\begin{array}{c}-0.199 * * * \\
(-6.474)\end{array}$ & $\begin{array}{c}-0.191 * * * \\
(-6.566)\end{array}$ \\
\hline Post TARP $x$ TARP Bank & $\begin{array}{c}-0.630 * * * \\
(-2.894) \\
\end{array}$ & $\begin{array}{c}-0.349 * * \\
(-2.249)\end{array}$ & $\begin{array}{c}-1.706^{* * * *} \\
(-7.234) \\
\end{array}$ & $\begin{array}{c}-1.041 * * * \\
(-6.198) \\
\end{array}$ & $\begin{array}{c}-0.678 * * * \\
(-3.148) \\
\end{array}$ & $\begin{array}{l}-0.382 * * \\
(-2.500) \\
\end{array}$ & $\begin{array}{c}-1.754 * * * \\
(-7.514) \\
\end{array}$ & $\begin{array}{c}-1.076^{* * *} \\
(-6.523) \\
\end{array}$ \\
\hline Capital Adequacy & $\begin{array}{c}-21.338 * * * \\
(-12.349)\end{array}$ & $\begin{array}{c}-14.276 * * * \\
(-11.451)\end{array}$ & & & $\begin{array}{c}-20.465^{* * *} \\
(-12.364)\end{array}$ & $\begin{array}{c}-13.920 * * * \\
(-11.583)\end{array}$ & & \\
\hline Asset Quality & $\begin{array}{c}-5.463 * * \\
(-2.412)\end{array}$ & $\begin{array}{l}-2.842 * \\
(-1.854)\end{array}$ & & & $\begin{array}{c}-6.555^{* * *} \\
(-3.146)\end{array}$ & $\begin{array}{c}-5.077 * * * \\
(-3.620)\end{array}$ & & \\
\hline Management Quality & $\begin{array}{c}-2.924 * * * \\
(-4.101)\end{array}$ & $\begin{array}{c}-1.781 * * * \\
(-3.350)\end{array}$ & & & $\begin{array}{c}-2.971 * * * \\
(-4.142)\end{array}$ & $\begin{array}{c}-1.820 * * * \\
(-3.412)\end{array}$ & & \\
\hline Earnings (ROA) & $\begin{array}{c}-20.474 * * * \\
(-10.597)\end{array}$ & $\begin{array}{c}-12.931 * * * \\
(-9.650)\end{array}$ & & & $\begin{array}{c}-21.281 * * * \\
(-10.919)\end{array}$ & $\begin{array}{c}-13.444 * * * \\
(-10.002)\end{array}$ & & \\
\hline Liquidity & $\begin{array}{c}2.199 * * * \\
(5.057)\end{array}$ & $\begin{array}{c}1.412 * * * \\
(4.576)\end{array}$ & & & $\begin{array}{c}1.816^{* * * *} \\
(4.599)\end{array}$ & $\begin{array}{c}1.077 * * * \\
(3.735)\end{array}$ & & \\
\hline Sensitivity to Market Risk & $\begin{array}{c}0.396^{* * *} \\
(1.996)\end{array}$ & $\begin{array}{l}0.274 * \\
(1.824)\end{array}$ & & & $\begin{array}{c}0.057 \\
(0.293)\end{array}$ & $\begin{array}{c}0.018 \\
(0.118)\end{array}$ & & \\
\hline Bank Size & $\begin{array}{l}-0.045^{* *} \\
(-2.095)\end{array}$ & $\begin{array}{c}-0.066^{* * *} \\
(-4.324)\end{array}$ & $\begin{array}{c}-0.147 * * * \\
(-5.728)\end{array}$ & $\begin{array}{c}-0.130 * * * \\
(-7.176)\end{array}$ & & & & \\
\hline Bank Age & $\begin{array}{c}-0.001 * * * \\
(-5.372)\end{array}$ & $\begin{array}{c}-0.000 * * * \\
(-4.298)\end{array}$ & $\begin{array}{c}-0.001 * * * \\
(-4.281)\end{array}$ & $\begin{array}{c}-0.000 * * * \\
(-3.433)\end{array}$ & & & & \\
\hline$M \& A$ & $\begin{array}{c}0.135 * * * \\
(3.135)\end{array}$ & $\begin{array}{c}0.093^{* * * *} \\
(3.109)\end{array}$ & $\begin{array}{c}0.366 * * * \\
(7.152)\end{array}$ & $\begin{array}{c}0.239 * * * \\
(6.832)\end{array}$ & & & & \\
\hline BHC Indicator & $\begin{array}{c}0.040 * * * \\
(5.872)\end{array}$ & $\begin{array}{c}0.024 * * * \\
(4.468)\end{array}$ & $\begin{array}{c}0.043 * * * \\
(4.630)\end{array}$ & $\begin{array}{c}0.024 * * * \\
(3.761)\end{array}$ & & & & \\
\hline Metropolitan & $\begin{array}{c}0.371 * * * \\
(4.104)\end{array}$ & $\begin{array}{c}0.229 * * * \\
(3.706)\end{array}$ & $\begin{array}{c}0.304 * * * \\
(3.077)\end{array}$ & $\begin{array}{c}0.182 * * * \\
(2.790)\end{array}$ & & & & \\
\hline
\end{tabular}




\begin{tabular}{|c|c|c|c|c|c|c|c|c|}
\hline Total Branches / GTA & $\begin{array}{c}17.871 * * * \\
(4.843) \\
\end{array}$ & $\begin{array}{c}9.722 * * * \\
(4.056) \\
\end{array}$ & $\begin{array}{c}10.508 * * * \\
(2.709)\end{array}$ & $\begin{array}{l}5.060 * * \\
(2.025) \\
\end{array}$ & & & & \\
\hline Discount Window & $\begin{array}{c}0.004 \\
(0.080)\end{array}$ & $\begin{array}{l}-0.002 \\
(-0.065)\end{array}$ & $\begin{array}{c}0.057 \\
(1.050)\end{array}$ & $\begin{array}{c}0.032 \\
(0.845)\end{array}$ & & & & \\
\hline Term Auction Facility & $\begin{array}{c}0.151 * * * \\
(2.670)\end{array}$ & $\begin{array}{l}0.091 * * \\
(2.420)\end{array}$ & $\begin{array}{c}0.248 * * * \\
(3.731)\end{array}$ & $\begin{array}{c}0.152 * * * \\
(3.456)\end{array}$ & & & & \\
\hline SCAP / CCAR Participant & $\begin{array}{c}0.286^{* * * *} \\
(2.944)\end{array}$ & $\begin{array}{c}0.266^{* * * *} \\
(3.723)\end{array}$ & $\begin{array}{l}0.154 * \\
(1.675)\end{array}$ & $\begin{array}{c}0.178 * * * \\
(2.680)\end{array}$ & & & & \\
\hline Constant & $\begin{array}{l}3.802 * * * \\
(10.470) \\
\end{array}$ & $\begin{array}{c}2.342 * * * \\
(9.982) \\
\end{array}$ & $\begin{array}{c}1.345 * * * \\
(4.032) \\
\end{array}$ & $\begin{array}{l}3.093 * * * \\
(11.598) \\
\end{array}$ & $\begin{array}{l}3.942 * * * \\
(14.464) \\
\end{array}$ & $\begin{array}{l}1.928 * * * \\
(15.246) \\
\end{array}$ & $\begin{array}{c}0.173 * * * \\
(6.490) \\
\end{array}$ & $\begin{array}{l}1.840^{* * * *} \\
(10.808) \\
\end{array}$ \\
\hline Time Fixed Effects & YES & YES & YES & YES & YES & YES & YES & YES \\
\hline $\begin{array}{l}\text { Observations } \\
\text { Adjusted R-squared }\end{array}$ & $\begin{array}{l}7,395 \\
0.369 \\
\end{array}$ & $\begin{array}{l}7,269 \\
0.329 \\
\end{array}$ & $\begin{array}{l}7,396 \\
0.161\end{array}$ & $\begin{array}{l}7,270 \\
0.143\end{array}$ & $\begin{array}{l}7,395 \\
0.362 \\
\end{array}$ & $\begin{array}{l}7,269 \\
0.322 \\
\end{array}$ & $\begin{array}{l}7,650 \\
0.148 \\
\end{array}$ & $\begin{array}{l}7,513 \\
0.129 \\
\end{array}$ \\
\hline
\end{tabular}


Table 3: Effects of TARP on Systemic Risk - Instrumental Variable Analysis and Heckman Selection Model

This table shows difference-in-difference (DID) regression estimates for analyzing the impact of TARP on contributions to systemic risk using an instrumental variable approach as in Wooldridge Section 18.4.1 (Panels A and B) and Heckman (1979)'s Selection Model (Panels A and C). We use as instrument a political connections variable: Subcommittees on Financial Institutions or Capital Markets. Subcommittees on Financial Institutions or Capital Markets is a variable, which takes a value of 1 if a firm is headquartered in a district of a House member, who served on the Capital Markets Subcommittee or the Financial Institutions Subcommittee of the House Financial Services Committee in 2008 or 2009. The measures of contribution to systemic risk are the Expected Capital Shortfall (NSRISK) and the Systemic Expected Shortfall (SES). TARP Bank is a dummy equal to one if a bank was approved for TARP and received TARP funds, and 0 if it applied for TARP but was not approved, Post TARP is a dummy equal to one in 2009-2012, the period after TARP program initiation. In Panels B and C, columns (1) and (2) present results using the main specification model. Columns (3) and (4) present models which exclude the proxies for bank CAMELS. Columns (5) and (6) present models which exclude controls other than proxies for bank CAMELS. Columns (7) and (8) present models which exclude all controls. All models include time fixed effects. The estimation results are for 2005-2012. All variables are defined in Table $1 . *, * *$, and $* * *$ denote significance at $10 \%, 5 \%$, and $1 \%$ level.

Table 3 Panel A: First Stage - IV as in Wooldridge (Section 18.4.1) and Heckman (1979)'s Selection Model

\begin{tabular}{|c|c|c|c|c|}
\hline \multicolumn{5}{|c|}{ First Stage (Probit Model) } \\
\hline & $\begin{array}{c}\text { Main } \\
\text { Specification } \\
\end{array}$ & $\begin{array}{l}\text { Excluding Proxies } \\
\text { for CAMELS }\end{array}$ & $\begin{array}{l}\text { Excluding Controls } \\
\text { Other than CAMELS } \\
\end{array}$ & $\begin{array}{c}\text { Excluding All } \\
\text { Bank Controls } \\
\end{array}$ \\
\hline Dependent Variable: & TARP Bank & TARP Bank & TARP Bank & TARP Bank \\
\hline Independent Variables: & $(\mathbf{1})$ & $(2)$ & (3) & (4) \\
\hline $\begin{array}{l}\text { Subcommittees on Financial Institutions } \\
\text { or Capital Markets }\end{array}$ & $\begin{array}{c}0.510 * * * \\
(8.076)\end{array}$ & $\begin{array}{c}0.500 * * * \\
(8.141) \\
\end{array}$ & $\begin{array}{c}0.529 * * * \\
(9.327)\end{array}$ & $\begin{array}{c}0.496 * * * \\
(8.911) \\
\end{array}$ \\
\hline Proxies for CAMELS & YES & NO & YES & NO \\
\hline Bank Controls Other than CAMELS & YES & YES & NO & NO \\
\hline Other Government Programs & YES & YES & NO & NO \\
\hline Time Fixed Effects & YES & YES & YES & YES \\
\hline Observations & 7,395 & 7,396 & 7,395 & 7,396 \\
\hline Pseudo R-squared & 0.207 & 0.172 & 0.0782 & 0.0387 \\
\hline
\end{tabular}


Table 3 Panel B: Final Stage - IV as in Wooldridge (Section 18.4.1)

\begin{tabular}{|c|c|c|c|c|c|c|c|c|}
\hline \multirow[b]{3}{*}{ Dependent Variable: } & \multicolumn{6}{|c|}{ Final Stage (IV 2SLS) } & \multirow{2}{*}{\multicolumn{2}{|c|}{$\begin{array}{c}\text { Excluding All } \\
\text { Bank Controls }\end{array}$}} \\
\hline & \multicolumn{2}{|c|}{$\begin{array}{c}\text { Main } \\
\text { Specification } \\
\end{array}$} & \multicolumn{2}{|c|}{$\begin{array}{c}\text { Excluding Proxies } \\
\text { for CAMELS }\end{array}$} & \multicolumn{2}{|c|}{$\begin{array}{l}\text { Excluding Controls } \\
\text { Other than CAMELS } \\
\end{array}$} & & \\
\hline & NSRISK & SES & NSRISK & SES & NSRISK & SES & NSRISK & SES \\
\hline Independent Variables: & (1) & $(2)$ & (3) & (4) & (5) & (6) & (7) & (8) \\
\hline TARP Bank & $\begin{array}{c}0.612 * * \\
(2.012)\end{array}$ & $\begin{array}{c}0.217 \\
(0.988)\end{array}$ & $\begin{array}{c}0.138 \\
(0.394)\end{array}$ & $\begin{array}{c}0.070 \\
(0.305)\end{array}$ & $\begin{array}{c}2.367 * * * \\
(3.265)\end{array}$ & $\begin{array}{c}1.126 * * \\
(2.259)\end{array}$ & $\begin{array}{l}-0.351 * \\
(-1.734)\end{array}$ & $\begin{array}{c}-0.078 \\
(-0.420)\end{array}$ \\
\hline Post TARP x TARP Bank & $\begin{array}{c}-3.419 * * * \\
(-5.740)\end{array}$ & $\begin{array}{c}-2.166^{* * * *} \\
(-4.964) \\
\end{array}$ & $\begin{array}{c}-4.268 * * * \\
(-7.707)\end{array}$ & $\begin{array}{c}-2.684 * * * \\
(-7.153) \\
\end{array}$ & $\begin{array}{c}-10.303 * * * \\
(-6.769) \\
\end{array}$ & $\begin{array}{c}-6.094 * * * \\
(-5.718)\end{array}$ & $\begin{array}{c}-6.232 * * * \\
(-4.983)\end{array}$ & $\begin{array}{c}-4.026 * * * \\
(-4.684)\end{array}$ \\
\hline Proxies for CAMELS & YES & YES & No & No & YES & YES & No & No \\
\hline Bank Controls Other than CAMELS & YES & YES & YES & YES & No & No & No & NO \\
\hline Other Government Programs & YES & YES & YES & YES & No & No & No & No \\
\hline Time Fixed Effects & YES & YES & YES & YES & YES & YES & YES & YES \\
\hline Observations & 7,395 & 7,269 & 7,396 & 7,270 & 7,395 & 7,269 & 7,396 & 7,270 \\
\hline Adjusted R-squared & 0.327 & 0.287 & 0.116 & 0.104 & 0.175 & 0.165 & 0.106 & 0.094 \\
\hline $\begin{array}{l}\text { First Stage Kleibergen-Paap rk Wald F- } \\
\text { test }\end{array}$ & $163.250 * * *$ & $161.289 * * *$ & $87.954 * * *$ & $86.636^{* * * *}$ & $46.762 * * *$ & $47.664 * * *$ & $19.449 * * *$ & $18.608 * * *$ \\
\hline \multicolumn{9}{|c|}{ Table 3 Panel C: Heckman Selection Model - Outcome Equation } \\
\hline \multicolumn{9}{|c|}{ Heckman Selection Model (Outcome Equation) } \\
\hline & \multicolumn{2}{|c|}{$\begin{array}{c}\text { Main } \\
\text { Specification } \\
\end{array}$} & \multicolumn{2}{|c|}{$\begin{array}{c}\text { Excluding Proxies } \\
\text { for CAMELS } \\
\end{array}$} & \multicolumn{2}{|c|}{$\begin{array}{l}\text { Excluding Controls } \\
\text { Other than CAMELS } \\
\end{array}$} & \multicolumn{2}{|c|}{$\begin{array}{l}\text { Excluding All } \\
\text { Bank Controls } \\
\end{array}$} \\
\hline Dependent Variable: & NSRISK & $S E S$ & NSRISK & SES & NSRISK & SES & NSRISK & SES \\
\hline Independent Variables: & (1) & $(2)$ & (3) & (4) & $(\mathbf{5})$ & (6) & $(7)$ & (8) \\
\hline TARP Bank & $\begin{array}{c}-0.027 \\
(-0.085)\end{array}$ & $\begin{array}{c}-0.191 \\
(-0.783)\end{array}$ & $\begin{array}{c}-0.291 \\
(-0.826)\end{array}$ & $\begin{array}{c}-0.240 \\
(-0.989)\end{array}$ & $\begin{array}{c}-1.699 * * * \\
(-2.898)\end{array}$ & $\begin{array}{c}-1.349 * * * \\
(-2.965)\end{array}$ & $\begin{array}{c}-3.394 * * * \\
(-6.643)\end{array}$ & $\begin{array}{c}-2.118 * * * \\
(-5.498)\end{array}$ \\
\hline Post TARP x TARP Bank & $\begin{array}{c}-0.626 * * * \\
(-2.792) \\
\end{array}$ & $\begin{array}{c}-0.355 * * \\
(-2.191) \\
\end{array}$ & $\begin{array}{c}-1.719 * * * \\
(-7.224) \\
\end{array}$ & $\begin{array}{c}-1.051 * * * \\
(-6.136) \\
\end{array}$ & $\begin{array}{c}-0.789 * * * \\
(-3.381) \\
\end{array}$ & $\begin{array}{c}-0.466^{* * * *} \\
(-2.762) \\
\end{array}$ & $\begin{array}{c}-2.041 * * * \\
(-8.261) \\
\end{array}$ & $\begin{array}{c}-1.245 * * * \\
(-7.048) \\
\end{array}$ \\
\hline Lambda & $\begin{array}{c}-0.043 \\
(-0.230) \\
\end{array}$ & $\begin{array}{c}0.053 \\
(0.367) \\
\end{array}$ & $\begin{array}{c}0.102 \\
(0.494) \\
\end{array}$ & $\begin{array}{c}0.073 \\
(0.511) \\
\end{array}$ & $\begin{array}{c}0.911 * * * \\
(2.756)\end{array}$ & $\begin{array}{c}0.694 * * * \\
(2.703)\end{array}$ & $\begin{array}{c}1.798^{* * * *} \\
(6.183) \\
\end{array}$ & $\begin{array}{c}1.082 * * * \\
(4.936)\end{array}$ \\
\hline Proxies for CAMELS & YES & YES & NO & NO & YES & YES & NO & NO \\
\hline Bank Controls Other than CAMELS & YES & YES & YES & YES & NO & NO & NO & NO \\
\hline Other Government Programs & YES & YES & YES & YES & No & NO & No & No \\
\hline Time Fixed Effects & YES & YES & YES & YES & YES & YES & YES & YES \\
\hline Observations & 7,395 & 7,269 & 7,395 & 7,269 & 7,395 & 7,269 & 7,396 & 7,270 \\
\hline Adjusted R-squared & 0.368 & 0.329 & 0.161 & 0.144 & 0.364 & 0.324 & 0.148 & 0.128 \\
\hline
\end{tabular}


Table 4: Effects of TARP on Systemic Risk: Propensity Score Matching (PSM) Analysis

This table reports difference-in-difference (DID) regression estimates for analyzing the impact of TARP on contributions to systemic risk when using a sample obtained from propensity score matching: nearest-neighbor matching: $\mathrm{N}=1$. The measures of these contributions are the Expected Capital Shortfall (NSRISK) and the Systemic Expected Shortfall (SES). TARP Bank is a dummy equal to one if a bank was approved for TARP and received TARP funds, and 0 if it applied for TARP but was not approved, Post TARP is a dummy equal to one in 2009-2012, the period after TARP program initiation. Columns (1) and (2) present results using the main specification model. Columns (3) and (4) present models which exclude the proxies for bank CAMELS. Columns (5) and (6) present models which exclude controls other than proxies for bank CAMELS. Columns (7) and (8) present models which exclude all controls. All models include time fixed effects. The estimation results are for 2005-2012. All variables are defined in Table 1. *,**, and *** denote significance at $10 \%, 5 \%$, and $1 \%$ level.

\begin{tabular}{|c|c|c|c|c|c|c|c|c|}
\hline \multicolumn{9}{|c|}{ Propensity Score Matching (PSM) Analysis: Nearest Neighbor Matching N=1 } \\
\hline & \multicolumn{2}{|c|}{ Main Specification } & \multicolumn{2}{|c|}{$\begin{array}{c}\text { Excluding Proxies } \\
\text { for CAMELS }\end{array}$} & \multicolumn{2}{|c|}{$\begin{array}{c}\text { Excluding Controls } \\
\text { Other than CAMELS } \\
\end{array}$} & \multicolumn{2}{|c|}{ Excluding All Bank Controls } \\
\hline Dependent Variable: & NSRISK & SES & NSRISK & SES & NSRISK & SES & NSRISK & SES \\
\hline Independent Variables: & (1) & $(2)$ & (3) & (4) & (5) & (6) & $(7)$ & (8) \\
\hline TARP Approved Bank & $\begin{array}{l}-0.096^{*} \\
(-1.735)\end{array}$ & $\begin{array}{l}-0.096^{* *} \\
(-2.225)\end{array}$ & $\begin{array}{c}-0.118^{* *} \\
(-2.471)\end{array}$ & $\begin{array}{c}-0.117 * * * \\
(-2.924)\end{array}$ & $\begin{array}{c}-0.125 * * \\
(-2.567)\end{array}$ & $\begin{array}{c}-0.120 * * * \\
(-3.108)\end{array}$ & $\begin{array}{c}-0.189 * * * \\
(-5.606)\end{array}$ & $\begin{array}{c}-0.169 * * * \\
(-5.376)\end{array}$ \\
\hline Post TARP x TARP Approved Bank & $\begin{array}{c}-0.633 * * * \\
(-2.815) \\
\end{array}$ & $\begin{array}{c}-0.340 * * \\
(-2.166) \\
\end{array}$ & $\begin{array}{c}-1.359 * * * \\
(-5.528) \\
\end{array}$ & $\begin{array}{c}-0.838 * * * \\
(-4.810) \\
\end{array}$ & $\begin{array}{c}-0.543 * * \\
(-2.427) \\
\end{array}$ & $\begin{array}{l}-0.274 * \\
(-1.776) \\
\end{array}$ & $\begin{array}{c}-1.260 * * * \\
(-5.092) \\
\end{array}$ & $\begin{array}{c}-0.763 * * * \\
(-4.402) \\
\end{array}$ \\
\hline Proxies for CAMELS & YES & YES & NO & NO & YES & YES & NO & NO \\
\hline Bank Controls Other than CAMELS & YES & YES & YES & YES & NO & NO & NO & NO \\
\hline Time Fixed Effects & YES & YES & YES & YES & YES & YES & YES & YES \\
\hline Observations & 2,145 & 2,089 & 2,145 & 2,089 & 2,145 & 2,089 & 2,217 & 2,156 \\
\hline Adjusted R-squared & 0.430 & 0.377 & 0.262 & 0.221 & 0.421 & 0.372 & 0.252 & 0.215 \\
\hline
\end{tabular}


Table 5: Effects of TARP on Systemic Risk: Placebo Experiment

This table reports difference-in-difference (DID) regression estimates for analyzing the impact of TARP on contributions to systemic risk. We use a placebo experiment, in which we fictionally assume that the TARP participation took place five years earlier and we still distinguish between banks that were approved for TARP and received TARP funds and those that were not approved according to their "true" TARP program. We define Placebo Post TARP as a dummy equal to one in 2004-2007, the period after the fictional TARP program initiation and we run the regressions by using the placebo-sample (2000-2007). The measures of contribution to systemic risk are the Expected Capital Shortfall (NSRISK) and the Systemic Expected Shortfall (SES). TARP Bank is a dummy equal to one if a bank was approved for TARP and received TARP funds, and 0 if it applied for TARP but was not approved, Post TARP is a dummy equal to one in 2009-2012, the period after TARP program initiation. Columns (1) and (2) present results using the main specification model. Columns (3) and (4) present models which exclude the proxies for bank CAMELS. Columns (5) and (6) present models which exclude controls other than proxies for bank CAMELS. Columns (7) and (8) present models which exclude all controls. All models include time fixed effects. The estimation results are for 2000-2007. All variables are defined in Table 1.

$*, * *$, and $* * *$ denote significance at $10 \%, 5 \%$, and $1 \%$ level.

Placebo Experiment (TARP Participation is Assumed to Have Taken Place Five Years Earlier)

\begin{tabular}{|c|c|c|c|c|c|c|c|c|}
\hline \multirow[b]{3}{*}{ Dependent Variable: } & \multicolumn{6}{|c|}{ Assuming TARP Occurred Five Years Earlier (Placebo Post TARP: 2004-2007) } & \multirow{2}{*}{\multicolumn{2}{|c|}{$\begin{array}{c}\text { Excluding All } \\
\text { Bank Controls }\end{array}$}} \\
\hline & \multicolumn{2}{|c|}{$\begin{array}{c}\text { Main } \\
\text { Specification }\end{array}$} & \multicolumn{2}{|c|}{$\begin{array}{c}\text { Excluding Proxies } \\
\text { for CAMELS }\end{array}$} & \multicolumn{2}{|c|}{$\begin{array}{c}\text { Excluding Controls } \\
\text { Other than CAMELS }\end{array}$} & & \\
\hline & NSRISK & SES & NSRISK & SES & NSRISK & $S E S$ & NSRISK & $S E S$ \\
\hline Independent Variables: & (1) & (2) & (3) & (4) & (5) & (6) & (7) & (8) \\
\hline TARP Bank & $\begin{array}{c}-0.043 * * * \\
(-2.886)\end{array}$ & $\begin{array}{c}-0.031 * * * \\
(-3.175)\end{array}$ & $\begin{array}{c}-0.039 * * \\
(-2.518)\end{array}$ & $\begin{array}{l}-0.019 * \\
(-1.685)\end{array}$ & $\begin{array}{c}-0.036 * * * \\
(-2.583)\end{array}$ & $\begin{array}{c}-0.037 * * * \\
(-3.743)\end{array}$ & $\begin{array}{c}-0.048 * * * \\
(-3.237)\end{array}$ & $\begin{array}{c}-0.040 * * * \\
(-3.685)\end{array}$ \\
\hline Placebo Post TARP x TARP Bank & $\begin{array}{c}0.031 * * \\
(2.002) \\
\end{array}$ & $\begin{array}{l}0.022 * * \\
(2.092) \\
\end{array}$ & $\begin{array}{c}0.025 \\
(1.539) \\
\end{array}$ & $\begin{array}{r}0.015 \\
(1.251) \\
\end{array}$ & $\begin{array}{l}0.027 * \\
(1.707) \\
\end{array}$ & $\begin{array}{c}0.028 * * \\
(2.562)\end{array}$ & $\begin{array}{c}0.022 \\
(1.370)\end{array}$ & $\begin{array}{l}0.022 * \\
(1.821)\end{array}$ \\
\hline Proxies for CAMELS & YES & YES & NO & NO & YES & YES & NO & NO \\
\hline Bank Controls Other than CAMELS & YES & YES & YES & YES & NO & NO & NO & NO \\
\hline Other Government Programs & YES & YES & YES & YES & No & NO & NO & NO \\
\hline Time Fixed Effects & YES & YES & YES & YES & YES & YES & YES & YES \\
\hline Observations & 5,913 & 6,244 & 5,913 & 6,244 & 6,011 & 6,344 & 6,035 & 6,370 \\
\hline Adjusted R-squared & 0.159 & 0.337 & 0.068 & 0.148 & 0.125 & 0.276 & 0.049 & 0.090 \\
\hline
\end{tabular}


Table 6: Alternative Measure of TARP

This table reports difference-in-difference (DID) regression estimates for the effects of TARP on contributions to systemic risk using an alternative measure for TARP support: $L n$ $(1+$ Bailout Amount). The measures of contribution to systemic risk are the Expected Capital Shortfall (NSRISK) and the Systemic Expected Shortfall (SES). TARP Bank is a dummy equal to one if a bank was approved for TARP and received TARP funds, and 0 if it applied for TARP but was not approved, Post TARP is a dummy equal to one in 2009-2012, the period after TARP program initiation. All models include time fixed effects. The estimation results are for 2005-2012. Columns (1) and (2) present results using the main specification model. Columns (3) and (4) present models which exclude the proxies for bank CAMELS. Columns (5) and (6) present models which exclude controls other than proxies for bank CAMELS. Columns (7) and (8) present models which exclude all controls. All variables are defined in Table 1. *, **, and *** denote significance at $10 \%, 5 \%$, and $1 \%$ level.

\begin{tabular}{|c|c|c|c|c|c|c|c|c|}
\hline \multicolumn{9}{|c|}{ Ln (1+ Bailout Amount) } \\
\hline \multirow[b]{2}{*}{ Dependent Variable: } & \multicolumn{2}{|c|}{$\begin{array}{c}\text { Main } \\
\text { Specification }\end{array}$} & \multicolumn{2}{|c|}{$\begin{array}{c}\text { Excluding Proxies } \\
\text { for CAMELS }\end{array}$} & \multicolumn{2}{|c|}{$\begin{array}{c}\text { Excluding Controls } \\
\text { Other than CAMELS } \\
\end{array}$} & \multicolumn{2}{|c|}{$\begin{array}{l}\text { Excluding All } \\
\text { Bank Controls }\end{array}$} \\
\hline & NSRISK & $S E S$ & NSRISK & SES & NSRISK & SES & NSRISK & SES \\
\hline Independent Variables: & (1) & (2) & (3) & (4) & (5) & (6) & (7) & (8) \\
\hline TARP Bank & $\begin{array}{l}-0.002 \\
(-0.411)\end{array}$ & $\begin{array}{c}-0.004 \\
(-1.325)\end{array}$ & $\begin{array}{c}-0.011^{* *} \\
(-2.556)\end{array}$ & $\begin{array}{c}-0.011 * * * \\
(-3.032)\end{array}$ & $\begin{array}{c}0.001 \\
(0.240)\end{array}$ & $\begin{array}{c}-0.007 * * * \\
(-2.637)\end{array}$ & $\begin{array}{c}-0.013 * * * \\
(-5.655)\end{array}$ & $\begin{array}{c}-0.016^{* * *} \\
(-7.218)\end{array}$ \\
\hline Proxies for CAMELS & YES & YES & NO & NO & YES & YES & NO & NO \\
\hline Bank Controls Other than CAMELS & YES & YES & YES & YES & NO & NO & NO & NO \\
\hline Other Government Programs & YES & YES & YES & YES & No & NO & NO & NO \\
\hline Time Fixed Effects & YES & YES & YES & YES & YES & YES & YES & YES \\
\hline Observations & 7,395 & 7,269 & 7,396 & 7,270 & 7,395 & 7,269 & 7,650 & 7,513 \\
\hline
\end{tabular}


Table 7: Alternative Measures of Bank Systemic Risk

This table reports difference-in-difference (DID) regression estimates for the effects of TARP on contributions to systemic risk using alternative measures for contributions to systemic risk: Marginal Expected Shortfall (MES), Leverage ( $L V G), \triangle C o V A R$ contribution to systemic risk measure, Systemic Factor2 (computed using factor analysis based on our two main prior proxies: NSRISK and SES), and Systemic Factor3 (computed using factor analysis based on three proxies of contributions to systemic risk: NSRISK, SES, and $\triangle$ CoVAR). TARP Bank is a dummy equal to one if a bank was approved for TARP and received TARP funds, and 0 if it applied for TARP but was not approved, Post TARP is a dummy equal to one in 2009-2012, the period after TARP initiation. All models include time fixed effects. The estimation results are for 2005-2012. Columns (1)-(5) present results using the main specification model. Columns (6)-(10) present models which exclude the proxies for bank CAMELS. Columns (11)-(15) present models which exclude controls other than proxies for bank CAMELS. Columns (16)-(20) present models which exclude all bank controls. All variables are defined in Table $1 . *, * *$, and *** denote significance at 10\%, $5 \%$, and $1 \%$ level.

\begin{tabular}{|c|c|c|c|c|c|c|c|c|c|c|}
\hline \multicolumn{11}{|c|}{ Alternative Measures of Systemic Risk } \\
\hline \multirow[b]{2}{*}{ Dependent Variable: } & \multicolumn{5}{|c|}{ Main Specification } & \multicolumn{5}{|c|}{ Excluding Proxies for CAMELS } \\
\hline & MES & $L V G$ & $\Delta$ CoVaR & Systemic Factor2 & Systemic Factor3 & MES & $L V G$ & $\Delta$ CoVaR & Systemic Factor2 & Systemic Factor3 \\
\hline Independent Variables: & (1) & (2) & (3) & (4) & (5) & (6) & (7) & (8) & (9) & (10) \\
\hline TARP Bank & $\begin{array}{c}-0.001^{* * *} \\
(-2.690)\end{array}$ & $\begin{array}{c}-2.595^{* * *} \\
(-2.895)\end{array}$ & $\begin{array}{c}0.002^{* * *} \\
(12.194)\end{array}$ & $\begin{array}{c}-0.054 * * \\
(-2.344)\end{array}$ & $\begin{array}{c}-0.054 * * \\
(-2.329)\end{array}$ & $\begin{array}{c}-0.001^{* * *} \\
(-3.566)\end{array}$ & $\begin{array}{c}-2.817 * * * \\
(-3.185)\end{array}$ & $\begin{array}{c}0.002^{* * *} \\
(12.191)\end{array}$ & $\begin{array}{c}-0.062^{* * * *} \\
(-2.807)\end{array}$ & $\begin{array}{c}-0.062 * * * \\
(-2.793)\end{array}$ \\
\hline Post TARP $x$ TARP Bank & $\begin{array}{c}-0.002 * * \\
(-2.170)\end{array}$ & $\begin{array}{c}-8.901 * * \\
(-2.299)\end{array}$ & $\begin{array}{c}-0.001 * * \\
(-2.020)\end{array}$ & $\begin{array}{c}-0.257 * * * \\
(-2.592)\end{array}$ & $\begin{array}{c}-0.257 * * * \\
(-2.595)\end{array}$ & $\begin{array}{c}-0.005^{* * *} \\
(-5.811)\end{array}$ & $\begin{array}{c}-26.150 * * * \\
(-6.240) \\
\end{array}$ & $\begin{array}{c}-0.000 \\
(-1.521)\end{array}$ & $\begin{array}{c}-0.729 * * * \\
(-6.789)\end{array}$ & $\begin{array}{c}-0.730 * * * \\
(-6.794)\end{array}$ \\
\hline Proxies for CAMELS & YES & YES & YES & YES & YES & No & NO & No & NO & NO \\
\hline Bank Controls Other than CAMELS & YES & YES & YES & YES & YES & YES & YES & YES & YES & YES \\
\hline Other Government Programs & YES & YES & YES & YES & YES & YES & YES & YES & YES & YES \\
\hline Time Fixed Effects & YES & YES & YES & YES & YES & YES & YES & YES & YES & YES \\
\hline Observations & 7,286 & 7,385 & 7,395 & 7,269 & 7,269 & 7,287 & 7,386 & 7,396 & 7,270 & 7,270 \\
\hline Adjusted R-squared & 0.896 & 0.328 & 0.539 & 0.357 & 0.357 & 0.876 & 0.143 & 0.534 & 0.155 & 0.155 \\
\hline
\end{tabular}

\begin{tabular}{|c|c|c|c|c|c|c|c|c|c|c|}
\hline \multirow[b]{2}{*}{ Dependent Variable: } & \multicolumn{5}{|c|}{ Excluding Controls Other than CAMELS } & \multicolumn{5}{|c|}{ Excluding All Bank Controls } \\
\hline & MES & $L V G$ & $\Delta$ CoVaR & Systemic Factor 2 & Systemic Factor 3 & MES & $L V G$ & $\Delta$ CoVaR & Systemic Factor 2 & Systemic Factor 3 \\
\hline Independent Variables: & (11) & (12) & (13) & $(\mathbf{1 4})$ & (15) & (16) & (17) & (18) & (19) & (20) \\
\hline TARP Bank & $\begin{array}{c}-0.001 * * * \\
(-5.764)\end{array}$ & $\begin{array}{c}-2.939 * * * \\
(-3.680)\end{array}$ & $\begin{array}{c}0.003 * * * \\
(20.654)\end{array}$ & $\begin{array}{c}-0.059 * * * \\
(-2.903)\end{array}$ & $\begin{array}{c}-0.059 * * * \\
(-2.873)\end{array}$ & $\begin{array}{c}-0.002^{* * *} \\
(-8.207)\end{array}$ & $\begin{array}{c}-4.594 * * * \\
(-6.595)\end{array}$ & $\begin{array}{c}0.003 * * * \\
(20.533)\end{array}$ & $\begin{array}{c}-0.110^{* * *} \\
(-6.582)\end{array}$ & $\begin{array}{c}-0.109 * * * \\
(-6.555)\end{array}$ \\
\hline Post TARP $x$ TARP Bank & $\begin{array}{l}-0.002 * * \\
(-2.527) \\
\end{array}$ & $\begin{array}{c}-9.780 * * \\
(-2.570) \\
\end{array}$ & $\begin{array}{c}-0.000 \\
(-0.231) \\
\end{array}$ & $\begin{array}{c}-0.278 * * * \\
(-2.841) \\
\end{array}$ & $\begin{array}{c}-0.278^{* * *} \\
(-2.844) \\
\end{array}$ & $\begin{array}{c}-0.005^{* * *} \\
(-6.172) \\
\end{array}$ & $\begin{array}{c}-27.157 * * * \\
(-6.593) \\
\end{array}$ & $\begin{array}{c}0.000 \\
(0.433) \\
\end{array}$ & $\begin{array}{c}-0.750 * * * \\
(-7.087) \\
\end{array}$ & $\begin{array}{c}-0.751 * * * \\
(-7.090) \\
\end{array}$ \\
\hline Proxies for CAMELS & YES & YES & YES & YES & YES & NO & NO & NO & NO & NO \\
\hline Bank Controls Other than CAMELS & No & NO & No & No & No & No & No & No & No & No \\
\hline Other Government Programs & NO & NO & NO & NO & NO & NO & NO & No & NO & NO \\
\hline Time Fixed Effects & YES & YES & YES & YES & YES & YES & YES & YES & YES & YES \\
\hline Observations & 7,286 & 7,385 & 7,395 & 7,269 & 7,269 & 7,531 & 7,640 & 7,650 & 7,513 & 7,513 \\
\hline Adjusted R-squared & 0.890 & 0.322 & 0.316 & 0.351 & 0.351 & 0.869 & 0.129 & 0.284 & 0.141 & 0.141 \\
\hline
\end{tabular}


Table 8: Alternative Econometric Models

This table reports difference-in-difference (DID) regression estimates for the impact of TARP on contributions to systemic risk using alternative econometric models: bank and time fixed effects in Panel A, state and time fixed effects in Panel B, models with errors clusters at the bank- time level in Panel C, models with errors clusters at the state- time level in Panel D, models bank and time fixed effects and errors clustered at the bank-time level in Panel E, and models state and time fixed effects and errors clustered at the state-time level in Panel F. The measures of contribution to systemic risk are the Expected Capital Shortfall (NSRISK) and the Systemic Expected Shortfall (SES). TARP Bank is a dummy equal to one if a bank was approved for TARP and received TARP funds, and 0 if it applied for TARP but was not approved, Post TARP is a dummy equal to one in 2009-2012, the period after TARP program initiation. Columns (1) and (2) present results using the main specification model. Columns (3) and (4) present models which exclude the proxies for bank CAMELS. Columns (5) and (6) present models which exclude controls other than proxies for bank CAMELS. Columns (7) and (8) present models which exclude all controls. All models include time fixed effects. The estimation results are for 2005-2012. All variables are defined in Table $1 . *, * *$, and $* * *$ denote significance at $10 \%, 5 \%$, and $1 \%$ level.

Table 8 Panel A: Regression Parameters - Bank \& Time Fixed Effects

\begin{tabular}{|c|c|c|c|c|c|c|c|c|}
\hline \multirow[b]{3}{*}{ Dependent Variable: } & \multicolumn{6}{|c|}{ Bank \& Time Fixed Effects } & \multirow{2}{*}{\multicolumn{2}{|c|}{$\begin{array}{c}\text { Excluding All } \\
\text { Bank Controls } \\
\end{array}$}} \\
\hline & \multicolumn{2}{|c|}{$\begin{array}{c}\text { Main } \\
\text { Specification } \\
\end{array}$} & \multicolumn{2}{|c|}{$\begin{array}{c}\text { Excluding Proxies } \\
\text { for CAMELS }\end{array}$} & \multicolumn{2}{|c|}{$\begin{array}{c}\text { Excluding Controls } \\
\text { Other than CAMELS } \\
\end{array}$} & & \\
\hline & NSRISK & $S E S$ & NSRISK & SES & NSRISK & SES & NSRISK & SES \\
\hline Independent Variables: & (1) & (2) & (3) & (4) & (5) & (6) & (7) & (8) \\
\hline Post TARP $x$ TARP Bank & $\begin{array}{c}-0.664 * * * \\
(-2.785) \\
\end{array}$ & $\begin{array}{l}-0.393 * * \\
(-2.204)\end{array}$ & $\begin{array}{c}-1.970 * * * \\
(-8.054) \\
\end{array}$ & $\begin{array}{c}-1.250 * * * \\
(-6.598) \\
\end{array}$ & $\begin{array}{c}-0.833 * * * \\
(-3.607)\end{array}$ & $\begin{array}{c}-0.493 * * * \\
(-2.866) \\
\end{array}$ & $\begin{array}{c}-2.216^{* * * *} \\
(-9.230)\end{array}$ & $\begin{array}{c}-1.414 * * * \\
(-7.553) \\
\end{array}$ \\
\hline Bank Controls Other than CAMELS & YES & YES & YES & YES & NO & NO & NO & NO \\
\hline Other Government Programs & YES & YES & YES & YES & NO & NO & NO & NO \\
\hline Time Fixed Effects & YES & YES & YES & YES & YES & YES & YES & YES \\
\hline Bank Fixed Effects & YES & YES & YES & YES & YES & YES & YES & YES \\
\hline Observations & 7,395 & 7,269 & 7,396 & 7,270 & 7,395 & 7,269 & 7,650 & 7,513 \\
\hline Adjusted R-squared & 0.509 & 0.461 & 0.361 & 0.330 & 0.505 & 0.458 & 0.350 & 0.320 \\
\hline
\end{tabular}


Table 8 Panel B: Regression Parameters - State \& Time Fixed Effects

\begin{tabular}{|c|c|c|c|c|c|c|c|c|}
\hline \multirow[b]{3}{*}{ Dependent Variable: } & \multicolumn{6}{|c|}{ State \& Time Fixed Effects } & \multirow{2}{*}{\multicolumn{2}{|c|}{$\begin{array}{c}\text { Excluding All } \\
\text { Bank Controls }\end{array}$}} \\
\hline & \multicolumn{2}{|c|}{$\begin{array}{c}\text { Main } \\
\text { Specification } \\
\end{array}$} & \multicolumn{2}{|c|}{$\begin{array}{l}\text { Excluding Proxies } \\
\text { for CAMELS }\end{array}$} & \multicolumn{2}{|c|}{$\begin{array}{c}\text { Excluding Controls } \\
\text { Other than CAMELS } \\
\end{array}$} & & \\
\hline & NSRISK & $S E S$ & NSRISK & $S E S$ & NSRISK & SES & NSRISK & $S E S$ \\
\hline Independent Variables: & $(\mathbf{1})$ & $(2)$ & (3) & (4) & $(5)$ & $(6)$ & $(7)$ & $(8)$ \\
\hline TARP Bank & $\begin{array}{c}0.012 \\
(0.196)\end{array}$ & $\begin{array}{c}-0.026 \\
(-0.550)\end{array}$ & $\begin{array}{c}0.090 \\
(1.487)\end{array}$ & $\begin{array}{c}0.025 \\
(0.516)\end{array}$ & $\begin{array}{c}0.042 \\
(0.778)\end{array}$ & $\begin{array}{l}-0.038 \\
(-0.895)\end{array}$ & $\begin{array}{c}0.022 \\
(0.448)\end{array}$ & $\begin{array}{l}-0.044 \\
(-1.061)\end{array}$ \\
\hline Post TARP x TARP Bank & $\begin{array}{c}-0.642 * * * \\
(-2.944) \\
\end{array}$ & $\begin{array}{l}-0.367 * * \\
(-2.339) \\
\end{array}$ & $\begin{array}{c}-1.672 * * * \\
(-7.083) \\
\end{array}$ & $\begin{array}{c}-1.032 * * * \\
(-6.076) \\
\end{array}$ & $\begin{array}{c}-0.689 * * * \\
(-3.208) \\
\end{array}$ & $\begin{array}{c}-0.398 * * * \\
(-2.591) \\
\end{array}$ & $\begin{array}{c}-1.760 * * * \\
(-7.613) \\
\end{array}$ & $\begin{array}{c}-1.094 * * * \\
(-6.613) \\
\end{array}$ \\
\hline Proxies for CAMELS & YES & YES & NO & No & YES & YES & No & No \\
\hline Bank Controls Other than CAMELS & YES & YES & YES & YES & NO & NO & NO & NO \\
\hline Other Government Programs & YES & YES & & & & & & \\
\hline Time Fixed Effects & YES & YES & YES & YES & YES & YES & YES & YES \\
\hline State Fixed Effects & YES & YES & YES & YES & YES & YES & YES & YES \\
\hline $\begin{array}{l}\text { Observations } \\
\text { Adjusted R-squared }\end{array}$ & $\begin{array}{r}7,395 \\
0.392 \\
\end{array}$ & $\begin{array}{l}7,269 \\
0.350 \\
\end{array}$ & $\begin{array}{r}7,396 \\
0.202 \\
\end{array}$ & $\begin{array}{c}7,270 \\
0.180 \\
\end{array}$ & $\begin{array}{c}7,395 \\
0.388 \\
\end{array}$ & $\begin{array}{c}7,269 \\
0.345 \\
\end{array}$ & $\begin{array}{r}7,650 \\
0.192 \\
\end{array}$ & $\begin{array}{r}7,513 \\
0.169 \\
\end{array}$ \\
\hline
\end{tabular}

Table 8 Panel C: Regression Parameters - Bank - Time Clusters

\begin{tabular}{|c|c|c|c|c|c|c|c|c|}
\hline \multicolumn{9}{|c|}{ Bank-Time Clusters } \\
\hline \multirow[b]{2}{*}{ Dependent Variable: } & \multicolumn{2}{|c|}{$\begin{array}{c}\text { Main } \\
\text { Specification } \\
\end{array}$} & \multicolumn{2}{|c|}{$\begin{array}{c}\text { Excluding Proxies } \\
\text { for CAMELS } \\
\end{array}$} & \multicolumn{2}{|c|}{$\begin{array}{l}\text { Excluding Controls } \\
\text { Other than CAMELS } \\
\end{array}$} & \multicolumn{2}{|c|}{$\begin{array}{c}\text { Excluding All } \\
\text { Bank Controls } \\
\end{array}$} \\
\hline & NSRISK & SES & NSRISK & SES & NSRISK & SES & NSRISK & $S E S$ \\
\hline Independent Variables: & (1) & $(2)$ & (3) & (4) & (5) & (6) & $(7)$ & (8) \\
\hline TARP Bank & $\begin{array}{c}-0.099 * * \\
(-2.020)\end{array}$ & $\begin{array}{c}-0.102 * * * \\
(-2.748)\end{array}$ & $\begin{array}{c}-0.113 * * * \\
(-2.582)\end{array}$ & $\begin{array}{c}-0.113^{* * *} \\
(-3.060)\end{array}$ & $\begin{array}{c}-0.086^{* *} \\
(-2.055)\end{array}$ & $\begin{array}{c}-0.121 * * * \\
(-3.634)\end{array}$ & $\begin{array}{c}-0.199 * * * \\
(-6.474)\end{array}$ & $\begin{array}{c}-0.191 * * * \\
(-6.566)\end{array}$ \\
\hline Post TARP $x$ TARP Bank & $\begin{array}{c}-0.630 * * * \\
(-2.894) \\
\end{array}$ & $\begin{array}{c}-0.349 * * \\
(-2.249) \\
\end{array}$ & $\begin{array}{c}-1.706 * * * \\
(-7.234) \\
\end{array}$ & $\begin{array}{c}-1.041 * * * \\
(-6.198) \\
\end{array}$ & $\begin{array}{c}-0.678 * * * \\
(-3.148) \\
\end{array}$ & $\begin{array}{c}-0.382 * * \\
(-2.500)\end{array}$ & $\begin{array}{c}-1.754 * * * \\
(-7.514) \\
\end{array}$ & $\begin{array}{c}-1.076^{* * *} \\
(-6.523) \\
\end{array}$ \\
\hline Proxies for CAMELS & YES & YES & No & No & YES & YES & No & No \\
\hline Bank Controls Other than CAMELS & YES & YES & YES & YES & No & No & No & No \\
\hline Other Government Programs & YES & YES & YES & YES & NO & No & No & No \\
\hline Time Fixed Effects & YES & YES & YES & YES & YES & YES & YES & YES \\
\hline Bank $x$ Time Clusters & YES & YES & YES & YES & YES & YES & YES & YES \\
\hline Observations & 7,395 & 7,269 & 7,396 & 7,270 & 7,395 & 7,269 & 7,650 & 7,513 \\
\hline Adjusted R-squared & 0.369 & 0.329 & 0.161 & 0.143 & 0.362 & 0.322 & 0.148 & 0.129 \\
\hline
\end{tabular}


Table 8 Panel D: Regression Parameters - State - Time Clusters

\begin{tabular}{|c|c|c|c|c|c|c|c|c|}
\hline \multirow[b]{3}{*}{ Dependent Variable: } & \multicolumn{6}{|c|}{ State-Time Clusters } & \multirow{2}{*}{\multicolumn{2}{|c|}{$\begin{array}{c}\text { Excluding All } \\
\text { Bank Controls }\end{array}$}} \\
\hline & \multicolumn{2}{|c|}{$\begin{array}{c}\text { Main } \\
\text { Specification } \\
\end{array}$} & \multicolumn{2}{|c|}{$\begin{array}{c}\text { Excluding Proxies } \\
\text { for CAMELS }\end{array}$} & \multicolumn{2}{|c|}{$\begin{array}{l}\text { Excluding Controls } \\
\text { Other than CAMELS } \\
\end{array}$} & & \\
\hline & NSRISK & $S E S$ & NSRISK & SES & NSRISK & SES & NSRISK & SES \\
\hline Independent Variables: & (1) & $(2)$ & (3) & (4) & (5) & (6) & $(7)$ & (8) \\
\hline TARP Bank & $\begin{array}{l}-0.099 * * \\
(-2.142)\end{array}$ & $\begin{array}{c}-0.102 * * * \\
(-2.834)\end{array}$ & $\begin{array}{l}-0.113 * * \\
(-2.515)\end{array}$ & $\begin{array}{c}-0.113^{* * *} \\
(-2.819)\end{array}$ & $\begin{array}{c}-0.086^{* *} \\
(-2.149)\end{array}$ & $\begin{array}{c}-0.121 * * * \\
(-3.698)\end{array}$ & $\begin{array}{c}-0.199 * * * \\
(-6.175)\end{array}$ & $\begin{array}{r}-0.191 * * * \\
(-5.802)\end{array}$ \\
\hline Post TARP $x$ TARP Bank & $\begin{array}{c}-0.630 * * * \\
(-2.968) \\
\end{array}$ & $\begin{array}{c}-0.349 * * \\
(-2.312) \\
\end{array}$ & $\begin{array}{c}-1.706^{* * * *} \\
(-7.530) \\
\end{array}$ & $\begin{array}{c}-1.041 * * * \\
(-6.471) \\
\end{array}$ & $\begin{array}{c}-0.678 * * * \\
(-3.244) \\
\end{array}$ & $\begin{array}{c}-0.382 * * * \\
(-2.586) \\
\end{array}$ & $\begin{array}{c}-1.754 * * * \\
(-7.844) \\
\end{array}$ & $\begin{array}{r}-1.076^{* * * *} \\
(-6.852) \\
\end{array}$ \\
\hline Proxies for CAMELS & YES & YES & No & No & YES & YES & No & No \\
\hline Bank Controls Other than CAMELS & YES & YES & YES & YES & No & No & No & No \\
\hline Other Government Programs & YES & YES & YES & YES & NO & No & No & No \\
\hline Time Fixed Effects & YES & YES & YES & YES & YES & YES & YES & YES \\
\hline State $x$ Time Clusters & YES & YES & YES & YES & YES & YES & YES & YES \\
\hline Observations & 7,395 & 7,269 & 7,396 & 7,270 & 7,395 & 7,269 & 7,650 & 7,513 \\
\hline Adjusted R-squared & 0.369 & 0.329 & 0.161 & 0.143 & 0.362 & 0.322 & 0.148 & 0.129 \\
\hline
\end{tabular}

Table 8 Panel E: Regression Parameters - Bank \& Time Fixed Effects \& Bank - Time Clusters

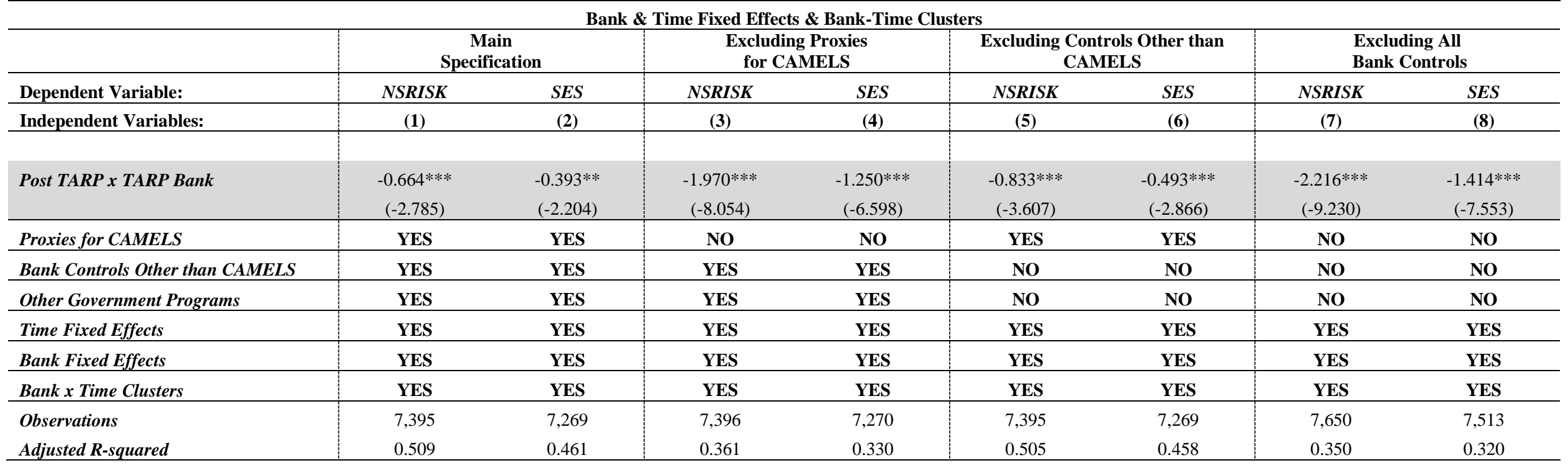


Table 8 Panel F: Regression Parameters - State \& Time Fixed Effects \& State - Time Clusters

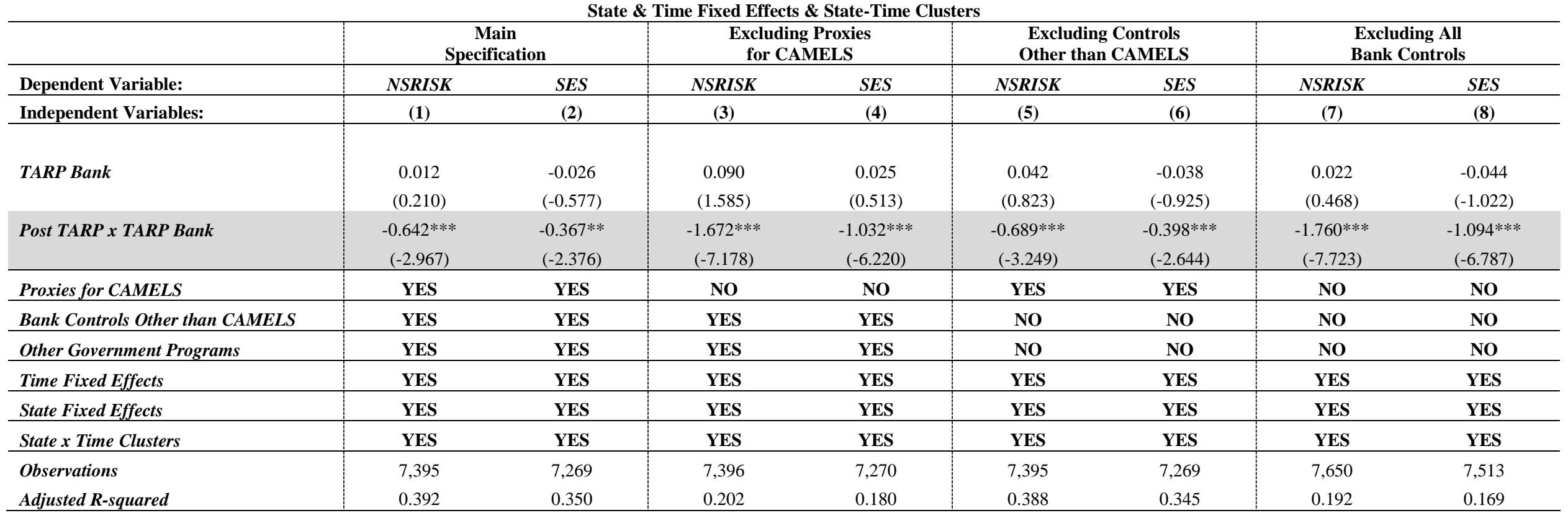


Table 9: Additional Robustness Tests

This table reports difference-in-difference (DID) regression estimates for the impact of TARP on contributions to systemic risk from additional robustness tests. Panel A reports estimates when controlling for systematic risk. Panel B reports estimates from a sample that excludes involuntary participants. Panel C reports estimates from a sample that excludes banks subject to stress-tests (SCAP and CCAR). Panel D reports estimates when controlling for more government programs: TAGP (FDIC Transaction Account Guarantee Program), TDGP (FDIC Temporary Debt Guarantee Program), SBLF (Small Business Lending Fund), and FHLB (Federal Home Loan Bank Membership). The measures of contribution to systemic risk are the Expected Capital Shortfall (NSRISK) and the Systemic Expected Shortfall (SES). TARP Bank is a dummy equal to one if a bank was approved for TARP and received TARP funds, and 0 if it applied for TARP but was not approved, Post TARP is a dummy equal to one in 2009-2012, the period after TARP program initiation. Columns (1) and (2) present results using the main specification model. Columns (3) and (4) present models which exclude the proxies for bank CAMELS. Columns (5) and (6) present models which exclude controls other than proxies for bank CAMELS. Columns (7) and (8) present models which exclude all controls. All models include time fixed effects. The estimation results are for 2005-2012. All variables are defined in Table 1. *,**, and *** denote significance at $10 \%, 5 \%$, and $1 \%$ level.

Table 9 Panel A: Controlling for Systematic Risk

\begin{tabular}{|c|c|c|c|c|c|c|c|c|}
\hline \multirow[b]{2}{*}{ Dependent Variable: } & \multicolumn{2}{|c|}{$\begin{array}{c}\text { Main } \\
\text { Specification }\end{array}$} & \multicolumn{2}{|c|}{$\begin{array}{l}\text { Excluding Proxies } \\
\text { for CAMELS }\end{array}$} & \multicolumn{2}{|c|}{$\begin{array}{l}\text { Excluding Controls } \\
\text { Other than CAMELS }\end{array}$} & \multicolumn{2}{|c|}{$\begin{array}{c}\text { Excluding All } \\
\text { Bank Controls }\end{array}$} \\
\hline & NSRISK & SES & NSRISK & SES & NSRISK & $S E S$ & NSRISK & $S E S$ \\
\hline Independent Variables: & (1) & $(2)$ & (3) & $(4)$ & $(5)$ & $(6)$ & $(7)$ & (8) \\
\hline TARP Bank & $\begin{array}{l}-0.090^{*} \\
(-1.775)\end{array}$ & $\begin{array}{c}-0.102 * * * \\
(-2.720)\end{array}$ & $\begin{array}{l}-0.089 * \\
(-1.936)\end{array}$ & $\begin{array}{c}-0.105 * * * \\
(-2.826)\end{array}$ & $\begin{array}{l}-0.092 * * \\
(-2.135)\end{array}$ & $\begin{array}{c}-0.120 * * * \\
(-3.631)\end{array}$ & $\begin{array}{c}-0.206 * * * \\
(-6.473)\end{array}$ & $\begin{array}{c}-0.191 * * * \\
(-6.569)\end{array}$ \\
\hline Post TARP x TARP Bank & $\begin{array}{c}-0.646 * * * \\
(-2.961) \\
\end{array}$ & $\begin{array}{c}-0.353 * * \\
(-2.272) \\
\end{array}$ & $\begin{array}{c}-1.753 * * * \\
(-7.435) \\
\end{array}$ & $\begin{array}{c}-1.062 * * * \\
(-6.301) \\
\end{array}$ & $\begin{array}{c}-0.684 * * * \\
(-3.166) \\
\end{array}$ & $\begin{array}{c}-0.376^{* *} \\
(-2.456) \\
\end{array}$ & $\begin{array}{c}-1.772 * * * \\
(-7.590) \\
\end{array}$ & $\begin{array}{c}-1.078 * * * \\
(-6.498) \\
\end{array}$ \\
\hline Systematic Risk & $\begin{array}{l}1.204 * * \\
(2.035) \\
\end{array}$ & $\begin{array}{c}0.263 \\
(0.688) \\
\end{array}$ & $\begin{array}{c}2.501 * * * \\
(4.023) \\
\end{array}$ & $\begin{array}{c}1.081 * * * \\
(2.675) \\
\end{array}$ & $\begin{array}{c}0.779 \\
(1.419) \\
\end{array}$ & $\begin{array}{c}-0.192 \\
(-0.539) \\
\end{array}$ & $\begin{array}{l}1.252 * * \\
(2.184) \\
\end{array}$ & $\begin{array}{c}0.078 \\
(0.207) \\
\end{array}$ \\
\hline Proxies for CAMELS & YES & YES & No & No & YES & YES & No & No \\
\hline Bank Controls Other than CAMELS & YES & YES & YES & YES & No & NO & NO & No \\
\hline Time Fixed Effects & YES & YES & YES & YES & YES & YES & YES & YES \\
\hline Observations & 7,295 & 7,267 & 7,296 & 7,268 & 7,295 & 7,267 & 7,540 & 7,511 \\
\hline Adjusted R-squared & 0.370 & 0.329 & 0.164 & 0.145 & 0.363 & 0.322 & 0.148 & 0.129 \\
\hline
\end{tabular}


Table 9 Panel B: Excluding TARP Involuntary Participants

\begin{tabular}{|c|c|c|c|c|c|c|c|c|}
\hline \multirow[b]{2}{*}{ Dependent Variable: } & \multicolumn{2}{|c|}{$\begin{array}{c}\text { Main } \\
\text { Specification } \\
\end{array}$} & \multicolumn{2}{|c|}{$\begin{array}{l}\text { Excluding Proxies } \\
\text { for CAMELS }\end{array}$} & \multicolumn{2}{|c|}{$\begin{array}{l}\text { Excluding Controls } \\
\text { Other than CAMELS } \\
\end{array}$} & \multicolumn{2}{|c|}{$\begin{array}{l}\text { Excluding All } \\
\text { Bank Controls } \\
\end{array}$} \\
\hline & NSRISK & $S E S$ & NSRISK & $S E S$ & NSRISK & $S E S$ & NSRISK & $S E S$ \\
\hline Independent Variables: & $(\mathbf{1})$ & $(2)$ & (3) & (4) & $(5)$ & $(6)$ & $(7)$ & (8) \\
\hline TARP Bank & $\begin{array}{l}-0.103 * * \\
(-2.097)\end{array}$ & $\begin{array}{c}-0.106^{* * *} \\
(-2.843)\end{array}$ & $\begin{array}{c}-0.116^{* * * *} \\
(-2.638)\end{array}$ & $\begin{array}{c}-0.115^{* * *} \\
(-3.106)\end{array}$ & $\begin{array}{l}-0.084 * * \\
(-1.976)\end{array}$ & $\begin{array}{l}-0.118^{* * *} \\
(-3.539)\end{array}$ & $\begin{array}{l}-0.200 * * * \\
(-6.511)\end{array}$ & $\begin{array}{c}-0.191 * * * \\
(-6.560)\end{array}$ \\
\hline Post TARP $x$ TARP Bank & $\begin{array}{c}-0.568 * * * \\
(-2.586) \\
\end{array}$ & $\begin{array}{l}-0.305^{* *} \\
(-1.964) \\
\end{array}$ & $\begin{array}{c}-1.683 * * * \\
(-7.131) \\
\end{array}$ & $\begin{array}{c}-1.024 * * * \\
(-6.094) \\
\end{array}$ & $\begin{array}{c}-0.623^{* * * *} \\
(-2.867) \\
\end{array}$ & $\begin{array}{l}-0.342 * * \\
(-2.237) \\
\end{array}$ & $\begin{array}{c}-1.732 * * * \\
(-7.419) \\
\end{array}$ & $\begin{array}{c}-1.060 * * * \\
(-6.421) \\
\end{array}$ \\
\hline Proxies for CAMELS & YES & YES & NO & NO & YES & YES & NO & NO \\
\hline Bank Controls Other than CAMELS & YES & YES & YES & YES & NO & NO & NO & NO \\
\hline Other Government Programs & YES & YES & YES & YES & NO & NO & NO & NO \\
\hline Time Fixed Effects & YES & YES & YES & YES & YES & YES & YES & YES \\
\hline Observations & 7,199 & 7,073 & 7,200 & 7,074 & 7,199 & 7,073 & 7,446 & 7,309 \\
\hline Adjusted R-squared & 0.372 & 0.332 & 0.162 & 0.145 & 0.366 & 0.326 & 0.149 & 0.130 \\
\hline
\end{tabular}

Table 9 Panel C: Excluding Participants Subject to the Stress Tests (SCAP and CCAR)

\begin{tabular}{|c|c|c|c|c|c|c|c|c|}
\hline \multirow[b]{2}{*}{ Dependent Variable: } & \multicolumn{2}{|c|}{$\begin{array}{c}\text { Main } \\
\text { Specification }\end{array}$} & \multicolumn{2}{|c|}{$\begin{array}{l}\text { Excluding Proxies } \\
\text { for CAMELS }\end{array}$} & \multicolumn{2}{|c|}{$\begin{array}{c}\text { Excluding Controls } \\
\text { Other than CAMELS }\end{array}$} & \multicolumn{2}{|c|}{$\begin{array}{l}\text { Excluding All } \\
\text { Bank Controls }\end{array}$} \\
\hline & NSRISK & SES & NSRISK & SES & NSRISK & SES & NSRISK & SES \\
\hline Independent Variables: & (1) & $(2)$ & (3) & (4) & $(5)$ & (6) & $(7)$ & (8) \\
\hline TARP Bank & $\begin{array}{c}-0.122 * * \\
(-2.441)\end{array}$ & $\begin{array}{c}-0.117 * * * \\
(-3.104)\end{array}$ & $\begin{array}{c}-0.134 * * * \\
(-3.027)\end{array}$ & $\begin{array}{c}-0.126 * * * \\
(-3.401)\end{array}$ & $\begin{array}{c}-0.103 * * \\
(-2.370)\end{array}$ & $\begin{array}{c}-0.127 * * * \\
(-3.765)\end{array}$ & $\begin{array}{c}-0.201 * * * \\
(-6.518)\end{array}$ & $\begin{array}{c}-0.189 * * * \\
(-6.473)\end{array}$ \\
\hline Post TARP $x$ TARP Bank & $\begin{array}{c}-0.525 * * \\
(-2.384)\end{array}$ & $\begin{array}{l}-0.274^{*} \\
(-1.762) \\
\end{array}$ & $\begin{array}{c}-1.645 * * * \\
(-6.963) \\
\end{array}$ & $\begin{array}{c}-0.999 * * * \\
(-5.936)\end{array}$ & $\begin{array}{c}-0.584 * * * \\
(-2.683) \\
\end{array}$ & $\begin{array}{c}-0.315^{* *} \\
(-2.059) \\
\end{array}$ & $\begin{array}{c}-1.694 * * * \\
(-7.245) \\
\end{array}$ & $\begin{array}{r}-1.034 * * * \\
(-6.257)\end{array}$ \\
\hline Proxies for CAMELS & YES & YES & No & NO & YES & YES & NO & No \\
\hline Bank Controls Other than CAMELS & YES & YES & YES & YES & NO & No & NO & NO \\
\hline Other Government Programs & YES & YES & YES & YES & NO & No & No & No \\
\hline Time Fixed Effects & YES & YES & YES & YES & YES & YES & YES & YES \\
\hline Observations & 6,937 & 6,811 & 6,938 & 6,812 & 6,937 & 6,811 & 7,175 & 7,038 \\
\hline Adjusted R-squared & 0.377 & 0.336 & 0.162 & 0.144 & 0.370 & 0.329 & 0.151 & 0.131 \\
\hline
\end{tabular}


Table 9 Panel D: Controlling for More Government Programs

\begin{tabular}{|c|c|c|c|c|c|c|c|c|}
\hline \multirow[b]{2}{*}{ Dependent Variable: } & \multicolumn{2}{|c|}{$\begin{array}{c}\text { Main } \\
\text { Specification } \\
\end{array}$} & \multicolumn{2}{|c|}{$\begin{array}{l}\text { Excluding Proxies } \\
\text { for CAMELS }\end{array}$} & \multicolumn{2}{|c|}{$\begin{array}{c}\text { Excluding Controls } \\
\text { Other than CAMELS } \\
\end{array}$} & \multicolumn{2}{|c|}{$\begin{array}{l}\text { Excluding All } \\
\text { Bank Controls }\end{array}$} \\
\hline & NSRISK & $S E S$ & NSRISK & $S E S$ & NSRISK & $S E S$ & NSRISK & $S E S$ \\
\hline Independent Variables: & $(\mathbf{1})$ & $(2)$ & (3) & (4) & (5) & (6) & $(7)$ & (8) \\
\hline TARP Approved Bank & $\begin{array}{c}0.148 * * \\
(2.053)\end{array}$ & $\begin{array}{l}0.097 * \\
(1.776)\end{array}$ & $\begin{array}{c}0.267 * * * \\
(3.659)\end{array}$ & $\begin{array}{c}0.172 * * * \\
(2.998)\end{array}$ & $\begin{array}{l}-0.086 * * \\
(-2.055)\end{array}$ & $\begin{array}{c}-0.121 * * * \\
(-3.634)\end{array}$ & $\begin{array}{c}-0.199 * * * \\
(-6.474)\end{array}$ & $\begin{array}{c}-0.191 * * * \\
(-6.566)\end{array}$ \\
\hline Post TARP x TARP Approved Bank & $\begin{array}{c}-0.739 * * * \\
(-3.278) \\
\end{array}$ & $\begin{array}{c}-0.448 * * * \\
(-2.756) \\
\end{array}$ & $\begin{array}{c}-1.887 * * * \\
(-7.818) \\
\end{array}$ & $\begin{array}{c}-1.187 * * * \\
(-6.807) \\
\end{array}$ & $\begin{array}{c}-0.678 * * * \\
(-3.148) \\
\end{array}$ & $\begin{array}{c}-0.382 * * \\
(-2.500) \\
\end{array}$ & $\begin{array}{c}-1.754 * * * \\
(-7.514) \\
\end{array}$ & $\begin{array}{c}-1.076 * * * \\
(-6.523) \\
\end{array}$ \\
\hline TAGP & $\begin{array}{c}0.410 * * * \\
(8.536)\end{array}$ & $\begin{array}{c}0.265^{* * *} \\
(7.880)\end{array}$ & $\begin{array}{c}0.377 * * * \\
(7.438)\end{array}$ & $\begin{array}{c}0.239 * * * \\
(6.679)\end{array}$ & & & & \\
\hline TDGP & $\begin{array}{c}0.209 * * * \\
(4.416)\end{array}$ & $\begin{array}{c}0.125^{* * *} \\
(3.838)\end{array}$ & $\begin{array}{c}0.303 * * * \\
(5.742)\end{array}$ & $\begin{array}{c}0.187 * * * \\
(5.168)\end{array}$ & & & & \\
\hline$S B L F$ & $\begin{array}{c}-0.433 * * * \\
(-4.405)\end{array}$ & $\begin{array}{c}-0.362 * * * \\
(-4.962)\end{array}$ & $\begin{array}{c}-0.703^{* * *} \\
(-6.017)\end{array}$ & $\begin{array}{c}-0.533 * * * \\
(-6.160)\end{array}$ & & & & \\
\hline Proxies for CAMELS & YES & YES & NO & NO & YES & YES & NO & NO \\
\hline Bank Controls Other than CAMELS & YES & YES & YES & YES & NO & NO & NO & NO \\
\hline Time Fixed Effects & YES & YES & YES & YES & YES & YES & YES & YES \\
\hline Observations & 7,395 & 7,269 & 7,396 & 7,270 & 7,395 & 7,269 & 7,650 & 7,513 \\
\hline Adjusted R-squared & 0.376 & 0.337 & 0.176 & 0.159 & 0.362 & 0.322 & 0.148 & 0.129 \\
\hline
\end{tabular}




\section{Table 10: Dynamics of the Effects of TARP on Systemic Risk}

This table reports difference-in-difference (DID) regression estimates for the timing of the effects of TARP on contributions to systemic risk. The measures of contribution to systemic risk are the Expected Capital Shortfall (NSRISK) and the Systemic Expected Shortfall (SES). TARP Bank is a dummy equal to one if a bank was approved for TARP and received TARP funds, and 0 if it applied for TARP but was not approved. Post TARP is a dummy equal to one in 2009-2012, the period after TARP program initiation. In this table, the coefficients are the interactions of the TARP Recipient variable with year dummies for each year after the TARP program was implemented (2009, 2010, 2011, and 2012). All models include time fixed effects. The estimation results are for 2005-2012. Columns (1) and (2) present results using the main specification model. Columns (3) and (4) present models which exclude the proxies for bank CAMELS. Columns (5) and (6) present models which exclude controls other than proxies for bank CAMELS. Columns (7) and (8) present models which exclude all controls. All variables are defined in Table 1. *,**, and *** denote significance at 10\%, 5\%, and $1 \%$ level.

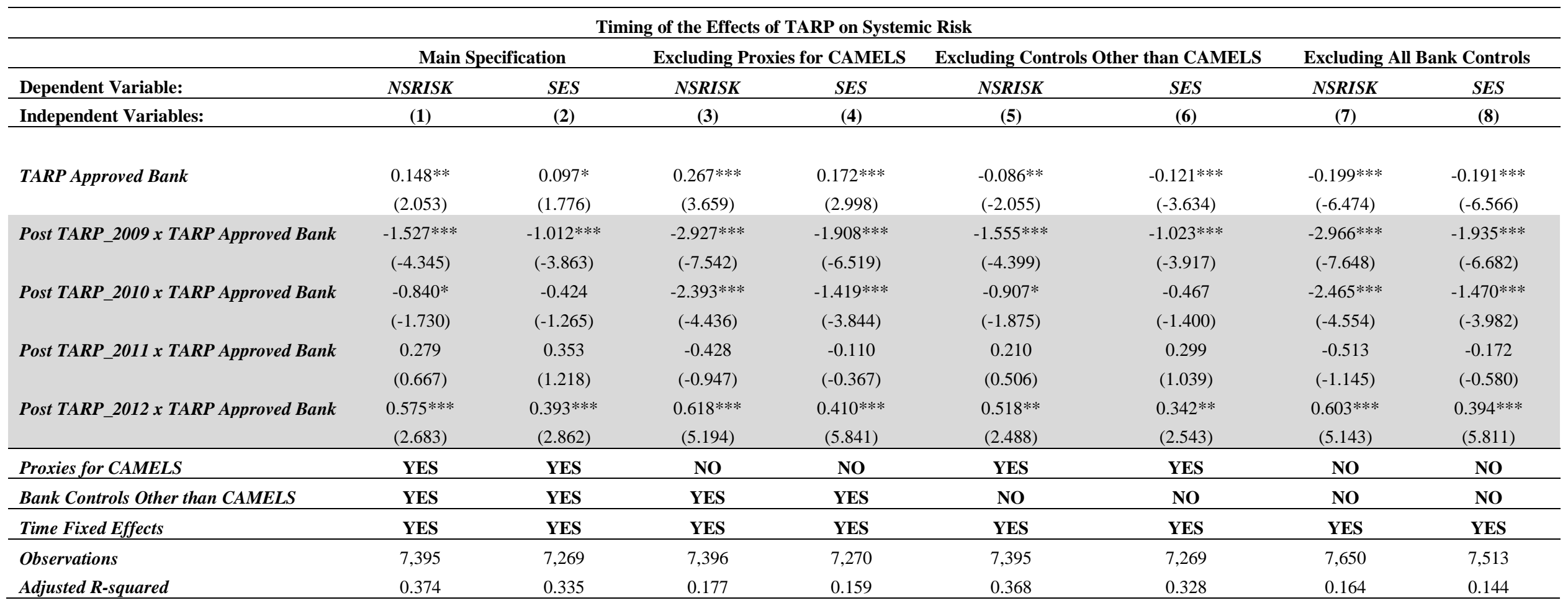


Table 11: Effects of TARP on Systemic Risk: Subsamples Analysis

This table shows additional subsample tests for analyzing the impact of TARP on contributions to systemic risk. Panel A reports difference-in-difference (DID) regression estimates when considering the different TARP banks size classes: SMALL (GTA $\leq 1$ Billion), MEDIUM (1 Billion < GTA $\leq 3$ Billion) and LARGE (GTA > 3 Billion). Panel B reports difference-in-difference (DID) regression estimates for the TARP banks with low contribution to systemic risk (systemic risk $\leq$ median) versus those with high contribution to systemic risk (systemic risk > median). Panel C reports difference-in-difference (DID) regression estimates for the TARP banks with low capitalization (EQCAP $08 Q 3 \leq$ median) versus those with high capitalization $\left(E Q C A P \_08 Q 3>\right.$ median). Panel D reports difference-in-difference (DID) regression estimates for the TARP banks in states with low coincident index in 2008:Q3 ( $\leq$ median) and those in states with high coincident index in 2008:Q3 (> median). The measures of contribution to systemic risk are the Expected Capital Shortfall (NSRISK) and the Systemic Expected Shortfall (SES). TARP Bank is a dummy equal to one if a bank was approved for TARP and received TARP funds, and 0 if it applied for TARP but was not approved, Post TARP is a dummy equal to one in 2009-2012, the period after TARP program initiation. Columns (1) and (2) present results using the main specification model. Columns (3) and (4) present models which exclude the proxies for bank CAMELS. Columns (5) and (6) present models which exclude controls other than proxies for bank CAMELS. Columns (7) and (8) present models which exclude all controls. All models include time fixed effects. The estimation results are for 2005-2012. All variables are defined in Table 1.*,**, and $* * *$ denote significance at $10 \%, 5 \%$, and $1 \%$ level.

Table 11 Panel A: Effects by Bank Size Classes - Panel A1: Regression Estimates

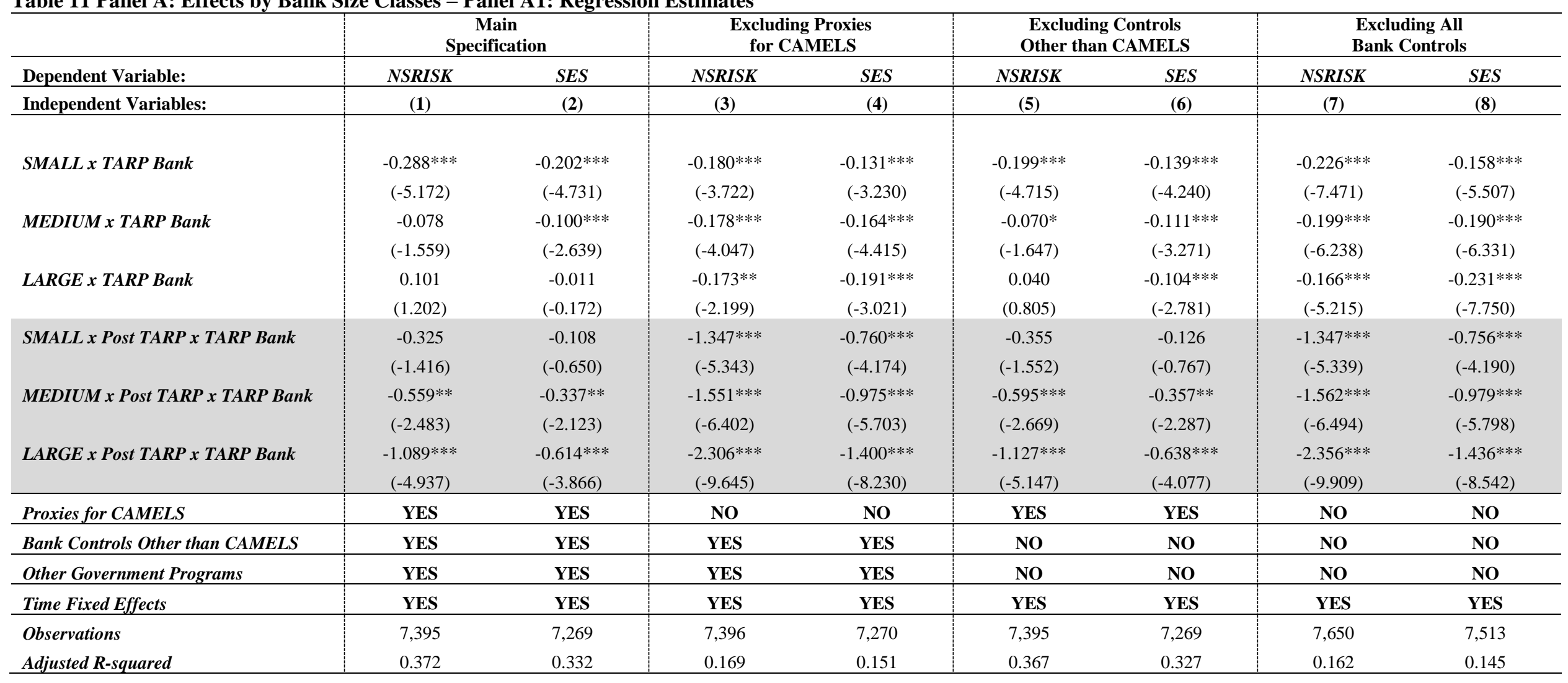


51

Table 11 Panel A2: Tests of the Equality of the Effects of TARP for Different Types of TARP Recipients

\begin{tabular}{|c|c|c|c|c|c|c|c|c|}
\hline \multirow[b]{2}{*}{ Dependent Variable: } & \multicolumn{2}{|c|}{$\begin{array}{c}\text { Main } \\
\text { Specification } \\
\end{array}$} & \multicolumn{2}{|c|}{$\begin{array}{l}\text { Excluding Proxies } \\
\text { for CAMELS } \\
\end{array}$} & \multicolumn{2}{|c|}{$\begin{array}{l}\text { Excluding Controls } \\
\text { Other than CAMELS } \\
\end{array}$} & \multicolumn{2}{|c|}{$\begin{array}{c}\text { Excluding All } \\
\text { Bank Controls } \\
\end{array}$} \\
\hline & NSRISK & SES & NSRISK & SES & NSRISK & SES & NSRISK & SES \\
\hline Independent Variables: & (1) & $(2)$ & (3) & (4) & (5) & (6) & $(7)$ & (8) \\
\hline $\begin{array}{l}\boldsymbol{t} \text {-stat: } \\
\text { Effect for small TARP banks (GTA } \leq 1 \text { Billion) }= \\
\text { effect for medium TARP banks (1 Billion }<\text { GTA } \\
\leq 3 \text { Billion) }\end{array}$ & $2.156^{* * *}$ & $2.877 * * *$ & 1.575 & $2.322 * *$ & $2.175 * *$ & $2.862 * * *$ & 1.631 & $2.377 * *$ \\
\hline $\begin{array}{l}t \text {-stat: } \\
\text { Effect for small TARP banks (GTA } \leq 1 \text { Billion) }= \\
\text { effect for large TARP banks (GTA }>5 \text { Billion) }\end{array}$ & $6.713 * * *$ & $5.992 * * *$ & $7.401 * * *$ & $6.765 * * *$ & $6.964 * * *$ & $6.177 * * *$ & $8.090 * * *$ & $7.423 * * *$ \\
\hline $\begin{array}{l}t \text {-stat: } \\
\text { Effect for medium TARP banks (1 Billion < GTA } \\
\leq 3 \text { Billion) }= \\
\text { effect for large TARP banks (GTA > 5 Billion) }\end{array}$ & $6.293 * * *$ & $4.753 * * *$ & $8.141 * * *$ & $6.880 * * *$ & $6.163 * * *$ & $4.698 * * *$ & $8.315^{* * *}$ & $7.215 * * *$ \\
\hline $\begin{array}{l}\boldsymbol{t} \text {-stat: } \\
\text { Effect for small TARP banks (GTA } \leq 1 \text { Billion) }= \\
\text { effect for medium TARP banks (1 Billion }<\text { GTA } \\
\leq 3 \text { Billion) }= \\
\text { effect for large TARP banks (GTA }>5 \text { Billion) }\end{array}$ & $5.445 * * *$ & $4.572 * * *$ & $6.686 * * *$ & $5.852 * * *$ & $5.580 * * *$ & $4.697 * * *$ & $7.169 * * *$ & $6.392 * * *$ \\
\hline
\end{tabular}

Table 11 Panel B: Low vs. High Contribution to Systemic Risk 2008:Q3

Table 11 Panel B1: Regression Estimates

\begin{tabular}{|c|c|c|c|c|c|c|c|c|}
\hline \multirow[b]{2}{*}{ Dependent Variable: } & \multicolumn{2}{|c|}{$\begin{array}{c}\text { Main } \\
\text { Specification } \\
\end{array}$} & \multicolumn{2}{|c|}{$\begin{array}{c}\text { Excluding Proxies } \\
\text { for CAMELS }\end{array}$} & \multicolumn{2}{|c|}{$\begin{array}{l}\text { Excluding Controls } \\
\text { Other than CAMELS } \\
\end{array}$} & \multicolumn{2}{|c|}{$\begin{array}{c}\text { Excluding All } \\
\text { Bank Controls } \\
\end{array}$} \\
\hline & NSRISK & SES & NSRISK & SES & NSRISK & $S E S$ & NSRISK & $S E S$ \\
\hline Independent Variables: & (1) & $(2)$ & (3) & (4) & (5) & (6) & (7) & (8) \\
\hline LOW SYSTEMIC RISK $x$ TARP Bank & $\begin{array}{c}-0.160 * * * \\
(-3.647)\end{array}$ & $\begin{array}{c}-0.126 * * * \\
(-3.656)\end{array}$ & $\begin{array}{c}-0.173 * * * \\
(-4.602)\end{array}$ & $\begin{array}{c}-0.183 * * * \\
(-5.469)\end{array}$ & $\begin{array}{c}-0.139 * * * \\
(-3.864)\end{array}$ & $\begin{array}{c}-0.140 * * * \\
(-4.651)\end{array}$ & $\begin{array}{c}-0.225 * * * \\
(-9.354)\end{array}$ & $\begin{array}{c}-0.237 * * * \\
(-9.208)\end{array}$ \\
\hline HIGH SYSTEMIC RISK $x$ TARP Bank & $\begin{array}{c}0.062 \\
(0.857)\end{array}$ & $\begin{array}{l}-0.087 * \\
(-1.856)\end{array}$ & $\begin{array}{c}-0.026 \\
(-0.377)\end{array}$ & $\begin{array}{c}-0.041 \\
(-0.877)\end{array}$ & $\begin{array}{c}0.066 \\
(0.964)\end{array}$ & $\begin{array}{l}-0.079 * \\
(-1.765)\end{array}$ & $\begin{array}{l}-0.110^{*} \\
(-1.878)\end{array}$ & $\begin{array}{c}-0.060 \\
(-1.409)\end{array}$ \\
\hline LOW SYSTEMIC RISK $x$ Post TARP $x$ TARP Bank & $\begin{array}{c}-1.228 * * * \\
(-5.771)\end{array}$ & $\begin{array}{c}-0.738 * * * \\
(-4.952)\end{array}$ & $\begin{array}{c}-2.849 * * * \\
(-12.246)\end{array}$ & $\begin{array}{c}-1.723 * * * \\
(-10.454)\end{array}$ & $\begin{array}{c}-1.312 * * * \\
(-6.232)\end{array}$ & $\begin{array}{c}-0.797 * * * \\
(-5.481)\end{array}$ & $\begin{array}{c}-2.969 * * * \\
(-12.811)\end{array}$ & $\begin{array}{c}-1.794 * * * \\
(-11.064)\end{array}$ \\
\hline HIGH SYSTEMIC RISK $x$ Post TARP $x$ TARP Bank & $\begin{array}{c}-0.678 * * * \\
(-2.973)\end{array}$ & $\begin{array}{l}-0.285^{*} \\
(-1.742)\end{array}$ & $\begin{array}{c}-1.529 * * * \\
(-6.195)\end{array}$ & $\begin{array}{c}-0.920 * * * \\
(-5.254)\end{array}$ & $\begin{array}{c}-0.705 * * * \\
(-3.124)\end{array}$ & $\begin{array}{c}-0.317 * * \\
(-1.979)\end{array}$ & $\begin{array}{c}-1.525 * * * \\
(-6.259)\end{array}$ & $\begin{array}{c}-0.947 * * * \\
(-5.509)\end{array}$ \\
\hline Proxies for CAMELS & YES & YES & NO & NO & YES & YES & NO & NO \\
\hline Bank Controls Other than CAMELS & YES & YES & YES & YES & NO & NO & NO & NO \\
\hline Time Fixed Effects & YES & YES & YES & YES & YES & YES & YES & YES \\
\hline Observations & 7,395 & 7,269 & 7,396 & 7,270 & 7,395 & 7,269 & 7,650 & 7,513 \\
\hline Adjusted R-squared & 0.377 & 0.337 & 0.192 & 0.176 & 0.372 & 0.332 & 0.184 & 0.170 \\
\hline
\end{tabular}


52

Table 11 Panel B2: Tests of the Equality of the Effects of TARP for Different Types of TARP Recipients

\begin{tabular}{|c|c|c|c|c|c|c|c|c|}
\hline \multirow[b]{2}{*}{ Dependent Variable: } & \multicolumn{2}{|c|}{$\begin{array}{c}\text { Main } \\
\text { Specification } \\
\end{array}$} & \multicolumn{2}{|c|}{$\begin{array}{c}\text { Excluding Proxies } \\
\text { for CAMELS } \\
\end{array}$} & \multicolumn{2}{|c|}{$\begin{array}{l}\text { Excluding Controls } \\
\text { Other than CAMELS } \\
\end{array}$} & \multicolumn{2}{|c|}{$\begin{array}{c}\text { Excluding All } \\
\text { Bank Controls } \\
\end{array}$} \\
\hline & NSRISK & SES & NSRISK & SES & NSRISK & SES & NSRISK & SES \\
\hline Independent Variables: & (1) & $(2)$ & (3) & (4) & $(5)$ & $(6)$ & $(7)$ & (8) \\
\hline $\begin{array}{l}\boldsymbol{t} \text {-stat: } \\
\text { Effect for states with low systemic risk = } \\
\text { effect for states with high systemic risk }\end{array}$ & $7.316 * * *$ & $9.955 * * *$ & $15.555 * * *$ & $15.343 * * *$ & $8.286 * * *$ & $10.648 * * *$ & $16.870 * * *$ & $15.987 * * *$ \\
\hline
\end{tabular}

Table 11 Panel C: Low vs. High Capitalization Level 2008:Q3

Table 11 Panel C1: Regression Estimates

\begin{tabular}{|c|c|c|c|c|c|c|c|c|}
\hline \multirow[b]{2}{*}{ Dependent Variable: } & \multicolumn{2}{|c|}{$\begin{array}{c}\text { Main } \\
\text { Specification } \\
\end{array}$} & \multicolumn{2}{|c|}{$\begin{array}{c}\text { Excluding Proxies } \\
\text { for CAMELS }\end{array}$} & \multicolumn{2}{|c|}{$\begin{array}{l}\text { Excluding Controls } \\
\text { Other than CAMELS } \\
\end{array}$} & \multicolumn{2}{|c|}{$\begin{array}{c}\text { Excluding All } \\
\text { Bank Controls } \\
\end{array}$} \\
\hline & NSRISK & $S E S$ & NSRISK & SES & NSRISK & $S E S$ & NSRISK & SES \\
\hline Independent Variables: & (1) & $(2)$ & (3) & (4) & $(\mathbf{5})$ & $(6)$ & $(7)$ & (8) \\
\hline LOW CAPITAL $x$ TARP Bank & $\begin{array}{c}-0.411 * * * \\
(-7.072)\end{array}$ & $\begin{array}{c}-0.302 * * * \\
(-6.911)\end{array}$ & $\begin{array}{c}-0.066 \\
(-1.527)\end{array}$ & $\begin{array}{l}-0.071^{*} \\
(-1.948)\end{array}$ & $\begin{array}{c}-0.431 * * * \\
(-8.280)\end{array}$ & $\begin{array}{c}-0.334 * * * \\
(-8.329)\end{array}$ & $\begin{array}{c}-0.189 * * * \\
(-6.053)\end{array}$ & $\begin{array}{c}-0.168 * * * \\
(-5.725)\end{array}$ \\
\hline HIGH CAPITAL $x$ TARP Bank & $\begin{array}{c}0.171 * * * \\
(3.056)\end{array}$ & $\begin{array}{l}0.069 * \\
(1.659)\end{array}$ & $\begin{array}{c}-0.157 * * * \\
(-3.379)\end{array}$ & $\begin{array}{c}-0.151 * * * \\
(-3.978)\end{array}$ & $\begin{array}{c}0.181 * * * \\
(3.551)\end{array}$ & $\begin{array}{c}0.045 \\
(1.180)\end{array}$ & $\begin{array}{c}-0.208 * * * \\
(-6.712)\end{array}$ & $\begin{array}{c}-0.211 * * * \\
(-7.203)\end{array}$ \\
\hline LOW CAPITAL $x$ Post TARP $x$ TARP Bank & $\begin{array}{c}-0.439 * * \\
(-2.006)\end{array}$ & $\begin{array}{c}-0.216 \\
(-1.378)\end{array}$ & $\begin{array}{c}-1.769 * * * \\
(-7.440)\end{array}$ & $\begin{array}{c}-1.073 * * * \\
(-6.309)\end{array}$ & $\begin{array}{c}-0.475 * * \\
(-2.185)\end{array}$ & $\begin{array}{c}-0.244 \\
(-1.576)\end{array}$ & $\begin{array}{c}-1.810 * * * \\
(-7.644)\end{array}$ & $\begin{array}{c}-1.103 * * * \\
(-6.565)\end{array}$ \\
\hline HIGH CAPITAL $x$ Post TARP $x$ TARP Bank & $\begin{array}{c}-0.642 * * * \\
(-2.855)\end{array}$ & $\begin{array}{c}-0.363 * * \\
(-2.268)\end{array}$ & $\begin{array}{c}-1.651 * * * \\
(-6.825)\end{array}$ & $\begin{array}{c}-1.012 * * * \\
(-5.909)\end{array}$ & $\begin{array}{c}-0.676 * * * \\
(-3.049)\end{array}$ & $\begin{array}{c}-0.389 * * \\
(-2.475)\end{array}$ & $\begin{array}{c}-1.706 * * * \\
(-7.150)\end{array}$ & $\begin{array}{c}-1.053 * * * \\
(-6.271)\end{array}$ \\
\hline Proxies for CAMELS & YES & YES & No & No & YES & YES & No & NO \\
\hline Bank Controls Other than CAMELS & YES & YES & YES & YES & No & No & No & NO \\
\hline Other Government Programs & YES & YES & YES & YES & No & No & No & No \\
\hline Time Fixed Effects & YES & YES & YES & YES & YES & YES & YES & YES \\
\hline Observations & 7,395 & 7,269 & 7,396 & 7,270 & 7,395 & 7,269 & 7,650 & 7,513 \\
\hline Adjusted R-squared & 0.376 & 0.335 & 0.161 & 0.143 & 0.372 & 0.329 & 0.148 & 0.129 \\
\hline
\end{tabular}

Table 11 Panel C2: Tests of the Equality of the Effects of TARP for Different Types of TARP Recipients

\begin{tabular}{|c|c|c|c|c|c|c|c|c|}
\hline \multirow[b]{2}{*}{ Dependent Variable: } & \multicolumn{2}{|c|}{$\begin{array}{c}\text { Main } \\
\text { Specification } \\
\end{array}$} & \multicolumn{2}{|c|}{$\begin{array}{l}\text { Excluding Proxies } \\
\text { for CAMELS }\end{array}$} & \multicolumn{2}{|c|}{$\begin{array}{l}\text { Excluding Controls } \\
\text { Other than CAMELS } \\
\end{array}$} & \multicolumn{2}{|c|}{$\begin{array}{c}\text { Excluding All } \\
\text { Bank Controls } \\
\end{array}$} \\
\hline & NSRISK & SES & NSRISK & SES & NSRISK & SES & NSRISK & SES \\
\hline Independent Variables: & (1) & (2) & (3) & (4) & (5) & (6) & (7) & (8) \\
\hline $\begin{array}{l}\boldsymbol{t} \text {-stat: } \\
\text { Effect for TARP banks with low capitalization = } \\
\text { effect for TARP banks with high capitalization }\end{array}$ & $2.659 * * *$ & $2.737 * * *$ & 1.304 & 0.975 & $2.592 * * *$ & $2.663 * * *$ & 1.131 & 0.794 \\
\hline
\end{tabular}


Table 11 Panel D: Exposure to Economic Shocks: Low vs. High Coincident Index 2008:Q3

Table 11 Panel D1: Regression Estimates

\begin{tabular}{|c|c|c|c|c|c|c|c|c|}
\hline \multirow[b]{2}{*}{ Dependent Variable: } & \multicolumn{2}{|c|}{$\begin{array}{c}\text { Main } \\
\text { Specification } \\
\end{array}$} & \multicolumn{2}{|c|}{$\begin{array}{c}\text { Excluding Proxies } \\
\text { for CAMELS }\end{array}$} & \multicolumn{2}{|c|}{$\begin{array}{l}\text { Excluding Controls } \\
\text { Other than CAMELS } \\
\end{array}$} & \multicolumn{2}{|c|}{$\begin{array}{c}\text { Excluding All } \\
\text { Bank Controls } \\
\end{array}$} \\
\hline & NSRISK & SES & NSRISK & $S E S$ & NSRISK & SES & NSRISK & SES \\
\hline Independent Variables: & (1) & $(2)$ & (3) & (4) & $(5)$ & $(6)$ & $(7)$ & (8) \\
\hline LOW COINCIDENT x TARP Bank & $\begin{array}{c}-0.200 * * * \\
(-4.137)\end{array}$ & $\begin{array}{c}-0.165 * * * \\
(-4.456)\end{array}$ & $\begin{array}{c}-0.195 * * * \\
(-4.733)\end{array}$ & $\begin{array}{c}-0.163 * * * \\
(-4.578)\end{array}$ & $\begin{array}{c}-0.177 * * * \\
(-4.147)\end{array}$ & $\begin{array}{c}-0.150 * * * \\
(-4.461)\end{array}$ & $\begin{array}{c}-0.222 * * * \\
(-7.089)\end{array}$ & $\begin{array}{c}-0.178 * * * \\
(-6.011)\end{array}$ \\
\hline HIGH COINCIDENT x TARP Bank & $\begin{array}{c}-0.030 \\
(-0.554)\end{array}$ & $\begin{array}{l}-0.065 \\
(-1.616)\end{array}$ & $\begin{array}{l}-0.105 * * \\
(-2.019)\end{array}$ & $\begin{array}{c}-0.115^{* * *} \\
(-2.815)\end{array}$ & $\begin{array}{l}-0.006 \\
(-0.134)\end{array}$ & $\begin{array}{c}-0.093 * * * \\
(-2.732)\end{array}$ & $\begin{array}{c}-0.181 * * * \\
(-5.842)\end{array}$ & $\begin{array}{c}-0.202 * * * \\
(-6.918)\end{array}$ \\
\hline LOW COINCIDENT x Post TARP x TARP Bank & $\begin{array}{l}-0.385^{*} \\
(-1.695)\end{array}$ & $\begin{array}{c}-0.181 \\
(-1.124)\end{array}$ & $\begin{array}{c}-1.393 * * * \\
(-5.698)\end{array}$ & $\begin{array}{c}-0.826 * * * \\
(-4.750)\end{array}$ & $\begin{array}{l}-0.419 * \\
(-1.863)\end{array}$ & $\begin{array}{l}-0.208 \\
(-1.313)\end{array}$ & $\begin{array}{c}-1.396 * * * \\
(-5.757)\end{array}$ & $\begin{array}{c}-0.831 * * * \\
(-4.851)\end{array}$ \\
\hline HIGH COINCIDENT $x$ Post TARP $x$ TARP Bank & $\begin{array}{c}-0.856 * * * \\
(-3.961) \\
\end{array}$ & $\begin{array}{c}-0.503 * * * \\
(-3.257)\end{array}$ & $\begin{array}{c}-1.981 * * * \\
(-8.369)\end{array}$ & $\begin{array}{c}-1.229 * * * \\
(-7.299)\end{array}$ & $\begin{array}{c}-0.912 * * * \\
(-4.265)\end{array}$ & $\begin{array}{c}-0.541 * * * \\
(-3.561)\end{array}$ & $\begin{array}{c}-2.051 * * * \\
(-8.735)\end{array}$ & $\begin{array}{c}-1.278 * * * \\
(-7.709)\end{array}$ \\
\hline Proxies for CAMELS & YES & YES & NO & No & YES & YES & No & No \\
\hline Bank Controls Other than CAMELS & YES & YES & YES & YES & No & NO & No & No \\
\hline Time Fixed Effects & YES & YES & YES & YES & YES & YES & YES & YES \\
\hline $\begin{array}{l}\text { Observations } \\
\text { Adjusted R-squared }\end{array}$ & $\begin{array}{l}7,395 \\
0.371\end{array}$ & $\begin{array}{l}7,269 \\
0.331 \\
\end{array}$ & $\begin{array}{l}7,396 \\
0.166 \\
\end{array}$ & $\begin{array}{l}7,270 \\
0.149\end{array}$ & $\begin{array}{l}7,395 \\
0.365\end{array}$ & $\begin{array}{l}7,269 \\
0.326 \\
\end{array}$ & $\begin{array}{l}7,650 \\
0.157 \\
\end{array}$ & $\begin{array}{l}7,513 \\
0.140 \\
\end{array}$ \\
\hline
\end{tabular}

Table 11 Panel D2: Tests of the Equality of the Effects of TARP for Different Types of TARP Recipients

\begin{tabular}{|c|c|c|c|c|c|c|c|c|}
\hline \multirow[b]{2}{*}{ Dependent Variable: } & \multicolumn{2}{|c|}{$\begin{array}{c}\text { Main } \\
\text { Specification } \\
\end{array}$} & \multicolumn{2}{|c|}{$\begin{array}{l}\text { Excluding Proxies } \\
\text { for CAMELS }\end{array}$} & \multicolumn{2}{|c|}{$\begin{array}{l}\text { Excluding Controls } \\
\text { Other than CAMELS }\end{array}$} & \multicolumn{2}{|c|}{$\begin{array}{c}\text { Excluding All } \\
\text { Bank Controls }\end{array}$} \\
\hline & NSRISK & SES & NSRISK & SES & NSRISK & SES & NSRISK & SES \\
\hline Independent Variables: & (1) & (2) & (3) & (4) & (5) & (6) & (7) & (8) \\
\hline $\begin{array}{l}t \text {-stat: } \\
\text { Effect for states with low coincident index }= \\
\text { effect for states with high coincident index }\end{array}$ & $5.876 * * *$ & $5.771 * * *$ & $6.146 * * *$ & $6.148 * * *$ & $6.158 * * *$ & $5.984 * * *$ & $6.796 * * *$ & $6.816^{* * * *}$ \\
\hline
\end{tabular}




\section{Appendix X - Description of the Troubled Asset Relief Program (TARP)}

In the recent financial crisis, the financial system was on the brink of collapse and the U.S. was suffering its worst economic recession since the 1930s. The U.S. government's response to the financial crisis and recession included bailouts as well as some of the most aggressive fiscal and monetary policies in its history and involved the Federal Reserve and other regulatory agencies, Congress, and two presidential administrations.

One of these responses was TARP, a fundamental component of the Emergency Economic Stabilization Act of 2008, H.R. 1424, signed on October 3, 2008. Originally, TARP was expected to be used to buy "toxic" securities on the secondary market. However, on October 14, the U.S. Treasury announced the Capital Purchase Program (CPP), a \$250 billion bank preferred stock and equity warrant purchase program led by the U.S. Treasury's Office of Financial Stability. We use the name TARP henceforth to refer to CPP, since this is the ultimate name widely used in the media, although CPP is only one of the interventions. On October 28 , the U.S. Treasury injected the first $\$ 125$ billion in preferred stock of nine large involuntary participants (Citigroup, Bank of America, J.P. Morgan Chase, Wells Fargo, Goldman Sachs Group, Morgan Stanley, State Street Corporation, Bank of New York, and Merrill Lynch). These initial recipients did not follow any formal TARP evaluation process. Later recipients followed a formal process and applied for TARP funds from the U.S. Treasury. TARP eventually infused capital of $\$ 204.9$ billion into 709 banking organizations. Approval to receive the rest of the TARP funds took into account the health of the banking organizations, with viable, healthier ones being more likely to receive capital. The size of the TARP investment in preferred shares was determined by the Treasury, ranging from 1-3\% of a firm's risk-weighted assets or $\$ 25$ billion (whichever was smaller). ${ }^{1}$ The main objectives of TARP, which were not independent of one another, were to enhance the overall stability of the financial system, increase the availability of credit, and improve real economic conditions.

In return for the capital infusion, banks provided the U.S. Treasury with non-voting preferred stock paying quarterly dividends at an annual yield of 5\% for the first five years and 9\% thereafter and ten-year life warrants for the common stock, giving taxpayers the opportunity to benefit from the banks' future growth. In addition, TARP participants were subject to compensation restrictions. Some of these restrictions were outlined at program inception in October 2008: limiting tax deductibility of compensation for senior executives to $\$ 500,000$, requiring bonus claw-backs, and restricting golden parachute payments. In February 2009, the Treasury revised the compensation rules and limited total annual compensation for

\footnotetext{
${ }^{1}$ Exceptions are Bank of America and Citigroup, which initially received $\$ 25$ billion, but later obtained more funds from the Targeted Investment Program (TIP) (Calomiris and Kahn, 2015).
} 
senior executives at TARP banks to $\$ 500,000$, excluding certain incentive awards. The American Recovery and Reinvestment Act (ARRA) further prohibited bonuses, retention awards, and incentive compensation other than long-term restricted stock awards that did not exceed one-third of annual compensation. In part as a result of these compensation restrictions, many banking organizations paid back the funds in 2009 and 2010. By December 31, 2012, the Treasury had received over \$220 billion in total cash back on \$204.9 billion TARP investments in banking organizations (more than $100 \%$ of the total disbursed). ${ }^{2}$

\footnotetext{
${ }^{2}$ http://www.treasury.gov/initiatives/financial-stability/reports/Pages/Monthly-Report-to-Congress.aspx
} 


\section{Appendix Y - Additional Robustness Tests}

This appendix contains additional robustness tests to assess for which bank types the TARP bailout program was most effective. Specifically, we investigate banks with cross-sectional differences in local market concentration, organizational complexity and structure, and internationalization status.

\section{Y.1 Effects by Local Market Concentration (HHI)}

In Table Y.1 Panel A1, columns (1)-(8), we group banks according to their local market concentration (HHI Deposits) and consider low concentration (HHI Deposits $\leq$ median) and high concentration (HHI Deposits $>$ median) banks. This is motivated by the debate about the effects of competition on financial stability, with some arguing that bank competition increases risk (the "competition-fragility" view), while others argue that competition reduces risk (the "competition-stability" view) ${ }^{1}$ The results suggest that the most reduction in contribution to systemic risk due to TARP occurs in the banks with high local market concentration. The $t$-tests in Panel A2 show that the differences are statistically significant for both measures of contribution to systemic risk.

\section{Y.2 Organizational Complexity and Structure}

In Table Y.1 Panel B1, columns (1)-(8), we group banks according to their organizational complexity as proxied by Total Branches / GTA. Banks that have more branches per dollar of assets are more complex (Berger and Bouwman, 2013) and it may be more difficult for them to adjust their risk. Other researchers also recognize the importance of organizational structure for bank behavior (e.g., Degryse and Ongena, 2005; Degryse, Laeven, and Ongena, 2009). We consider banks with low organization complexity (Total Branches / GTA $\leq$ median) and banks with high organization complexity (Total Branches / GTA > median). Results suggest that it is mostly the TARP banks with low organization complexity that were able to reduce their contribution to systemic risk, and the $t$-tests for the difference in coefficients between the groups reported in Panel B2 are statistically significant.

In Table Y.1 Panel C1, columns (1)-(8), we group banks according to their organizational structure and complexity into bank holding company (BHC) or standalone bank, as this may influence the institution's ability to reduce systemic risk. Bank holding companies establish internal capital markets to

\footnotetext{
${ }^{1}$ The "competition-fragility" view is supported by many (e.g., Marcus, 1984; Keeley, 1990; Demsetz, Saidenberg, and Strahan, 1996; Carletti and Hartmann, 2003), the "competition-stability" view is supported by others (e.g., Boyd and De Nicolo, 2005; Boyd, De Nicolo and Jalal, 2006, Schaeck, Cihak, and Wolfe, 2009). Berger, Klapper, and TurkAriss (2009) find that the two views do not necessarily yield opposing predictions and provide evidence supporting both. Martinez-Miera and Repullo (2010) predict a potential nonmonotonic relationship, and some empirical evidence supports this (e.g., Berger, Imbierowicz, and Rauch, 2016).
} 
allocate capital among their various subsidiaries (e.g., Houston, James, and Marcus, 1997). This can be a source of strength and help them reduce their risks. However, this structure can also make it more difficult to adjust their risks due to increased complexity. Our results suggest that both TARP banks organized as BHCs and standalone banks were able to reduce their contributions to systemic risk, with slightly more improvements for the BHCs. However, the $t$-tests for the difference in coefficients between the groups reported in Panel C2 are not statistically significant.

\section{Y.3 Internationalization}

In Table Y.1 Panel D1, columns (1)-(8), we group banks according to their internationalization status: international and purely domestic. International is a dummy equal to one if a bank has a positive foreign asset to GTA ratio and zero otherwise. As discussed in Berger, El Ghoul, Guedhami, and Roman (forthcoming), internationalization can be an important factor affecting bank risk, and it can go both ways. The results suggest that both international and purely domestic TARP banks reduced their contribution to systemic risk, but international TARP banks reduced their contribution to systemic risk statistically significantly more, and the $t$-tests for the difference in coefficients between the groups reported in Panel D2 are statistically significant. 
Table Y.1: Effects of TARP on Systemic Risk: Subsamples Analysis

This table shows additional subsample tests for analyzing the impact of TARP on contributions to systemic risk. Panel A reports difference-in-difference (DID) regression estimates for the TARP banks with low HHI (HHI Deposits $\leq$ median) versus those with high HHI (HHI Deposits > median). Panel B reports difference-in-difference (DID) regression estimates for the TARP banks with low organizational complexity (Total Branches / GTA $\leq$ median) versus those with high organizational complexity (Total Branches / GTA > median). Panel C reports difference-in-difference (DID) regression estimates for the TARP institutions that are bank holding companies versus TARP institutions that are standalone banks. Panel D reports difference-in-difference (DID) regression estimates for the TARP banks that are international versus TARP banks that are purely domestic. The measures of contribution to systemic risk are the Expected Capital Shortfall (NSRISK) and the Systemic Expected Shortfall (SES). TARP Bank is a dummy equal to one if a bank was approved for TARP and received TARP funds, and 0 if it applied for TARP but was not approved, Post TARP is a dummy equal to one in 2009-2012, the period after TARP program initiation. Columns (1) and (2) present results using the main specification model. Columns (3) and (4) present models which exclude the proxies for bank CAMELS. Columns (5) and (6) present models which exclude controls other than proxies for bank CAMELS. Columns (7) and (8) present models which exclude all controls. All models include time fixed effects. The estimation results are for 2005-2012. All variables are defined in Table 1. *,**, and *** denote significance at 10\%, 5\%, and $1 \%$ level.

Table Y.1 Panel A: Low vs. High HHI TARP Banks

Table Y.1 Panel A1: Regression Estimates

\begin{tabular}{|c|c|c|c|c|c|c|c|c|}
\hline \multirow[b]{2}{*}{ Dependent Variable: } & \multicolumn{2}{|c|}{$\begin{array}{c}\text { Main } \\
\text { Specification } \\
\end{array}$} & \multicolumn{2}{|c|}{$\begin{array}{c}\text { Excluding Proxies } \\
\text { for CAMELS }\end{array}$} & \multicolumn{2}{|c|}{$\begin{array}{l}\text { Excluding Controls } \\
\text { Other than CAMELS } \\
\end{array}$} & \multicolumn{2}{|c|}{$\begin{array}{c}\text { Excluding All } \\
\text { Bank Controls } \\
\end{array}$} \\
\hline & NSRISK & SES & NSRISK & SES & NSRISK & SES & NSRISK & SES \\
\hline Independent Variables: & (1) & (2) & (3) & (4) & (5) & (6) & $(7)$ & $(8)$ \\
\hline LOW HHI $x$ TARP Bank & $\begin{array}{c}-0.077 \\
(-1.412)\end{array}$ & $\begin{array}{l}-0.098 * * \\
(-2.412)\end{array}$ & $\begin{array}{c}-0.029 \\
(-0.593)\end{array}$ & $\begin{array}{l}-0.065 \\
(-1.629)\end{array}$ & $\begin{array}{c}-0.154 * * * \\
(-3.570)\end{array}$ & $\begin{array}{c}-0.163 * * * \\
(-4.804)\end{array}$ & $\begin{array}{c}-0.205^{* * *} \\
(-6.640)\end{array}$ & $\begin{array}{c}-0.191 * * * \\
(-6.549)\end{array}$ \\
\hline HIGH HHI $x$ TARP Bank & $\begin{array}{l}-0.120 * * \\
(-2.292)\end{array}$ & $\begin{array}{c}-0.103 * * * \\
(-2.608)\end{array}$ & $\begin{array}{c}-0.208 * * * \\
(-4.113)\end{array}$ & $\begin{array}{c}-0.165^{* * *} \\
(-4.070)\end{array}$ & $\begin{array}{l}-0.014 \\
(-0.317)\end{array}$ & $\begin{array}{l}-0.075^{* *} \\
(-2.194)\end{array}$ & $\begin{array}{c}-0.193 * * * \\
(-6.159)\end{array}$ & $\begin{array}{c}-0.191 * * * \\
(-6.472)\end{array}$ \\
\hline LOW HHI $x$ Post TARP $x$ TARP Bank & $\begin{array}{l}-0.457 * * \\
(-2.095)\end{array}$ & $\begin{array}{c}-0.228 \\
(-1.466)\end{array}$ & $\begin{array}{c}-1.652 * * * \\
(-6.905)\end{array}$ & $\begin{array}{c}-1.001 * * * \\
(-5.884)\end{array}$ & $\begin{array}{l}-0.460 * * \\
(-2.124)\end{array}$ & $\begin{array}{l}-0.232 \\
(-1.505)\end{array}$ & $\begin{array}{c}-1.666 * * * \\
(-7.017)\end{array}$ & $\begin{array}{c}-1.013 * * * \\
(-6.038)\end{array}$ \\
\hline HIGH HHI $x$ Post TARP $x$ TARP Bank & $\begin{array}{c}-0.806 * * * \\
(-3.597)\end{array}$ & $\begin{array}{c}-0.470 * * * \\
(-2.953)\end{array}$ & $\begin{array}{c}-1.766 * * * \\
(-7.343) \\
\end{array}$ & $\begin{array}{c}-1.086^{* * *} \\
(-6.346)\end{array}$ & $\begin{array}{c}-0.864 * * * \\
(-3.915)\end{array}$ & $\begin{array}{c}-0.508 * * * \\
(-3.262)\end{array}$ & $\begin{array}{c}-1.829 * * * \\
(-7.671)\end{array}$ & $\begin{array}{c}-1.129 * * * \\
(-6.719)\end{array}$ \\
\hline Proxies for CAMELS & YES & YES & NO & NO & YES & YES & NO & NO \\
\hline Bank Controls Other than CAMELS & YES & YES & YES & YES & NO & NO & NO & NO \\
\hline Other Government Programs & YES & YES & YES & YES & No & NO & NO & NO \\
\hline Time Fixed Effects & YES & YES & YES & YES & YES & YES & YES & YES \\
\hline $\begin{array}{l}\text { Observations } \\
\text { Adjusted R-squared }\end{array}$ & $\begin{array}{l}7,395 \\
0.371 \\
\end{array}$ & $\begin{array}{l}7,269 \\
0.331 \\
\end{array}$ & $\begin{array}{l}7,396 \\
0.163 \\
\end{array}$ & $\begin{array}{l}7,270 \\
0.145 \\
\end{array}$ & $\begin{array}{l}7,395 \\
0.364 \\
\end{array}$ & $\begin{array}{l}7,269 \\
0.324 \\
\end{array}$ & $\begin{array}{l}7,650 \\
0.149 \\
\end{array}$ & $\begin{array}{l}7,513 \\
0.129 \\
\end{array}$ \\
\hline
\end{tabular}


Y-4

Table Y.1 Panel A2: Tests of the Equality of the Effects of TARP for Different Types of TARP Recipients

\begin{tabular}{|c|c|c|c|c|c|c|c|c|}
\hline \multirow[b]{2}{*}{ Dependent Variable: } & \multicolumn{2}{|c|}{$\begin{array}{c}\text { Main } \\
\text { Specification } \\
\end{array}$} & \multicolumn{2}{|c|}{$\begin{array}{c}\text { Excluding Proxies } \\
\text { for CAMELS }\end{array}$} & \multicolumn{2}{|c|}{$\begin{array}{l}\text { Excluding Controls } \\
\text { Other than CAMELS }\end{array}$} & \multicolumn{2}{|c|}{$\begin{array}{c}\text { Excluding All } \\
\text { Bank Controls } \\
\end{array}$} \\
\hline & NSRISK & SES & NSRISK & SES & NSRISK & SES & NSRISK & $S E S$ \\
\hline Independent Variables: & (1) & (2) & (3) & (4) & $(5)$ & $(6)$ & (7) & (8) \\
\hline $\begin{array}{l}\boldsymbol{t} \text {-stat: } \\
\text { Effect for TARP banks with low HHI = } \\
\text { effect for TARP banks with high HHI }\end{array}$ & $4.410 * * *$ & $4.263^{* * *}$ & 1.233 & 1.345 & $5.117 * * *$ & $4.914 * * *$ & $1.744 *$ & $1.833^{*}$ \\
\hline
\end{tabular}

Table Y.1 Panel B: Low vs. High Organizational Complexity

Table Y.1 Panel B1: Regression Estimates

\begin{tabular}{|c|c|c|c|c|c|c|c|c|}
\hline \multirow[b]{2}{*}{ Dependent Variable: } & \multicolumn{2}{|c|}{$\begin{array}{c}\text { Main } \\
\text { Specification } \\
\end{array}$} & \multicolumn{2}{|c|}{$\begin{array}{l}\text { Excluding Proxies } \\
\text { for CAMELS }\end{array}$} & \multicolumn{2}{|c|}{$\begin{array}{l}\text { Excluding Controls } \\
\text { Other than CAMELS }\end{array}$} & \multicolumn{2}{|c|}{$\begin{array}{l}\text { Excluding All } \\
\text { Bank Controls }\end{array}$} \\
\hline & NSRISK & $S E S$ & NSRISK & $S E S$ & NSRISK & SES & NSRISK & $S E S$ \\
\hline Independent Variables: & $(\mathbf{1})$ & $(2)$ & (3) & (4) & (5) & $(6)$ & $(7)$ & (8) \\
\hline LOW COMPLEXITY $x$ TARP Bank & $\begin{array}{l}-0.007 \\
(-0.135)\end{array}$ & $\begin{array}{l}-0.069 * \\
(-1.697)\end{array}$ & $\begin{array}{c}0.042 \\
(0.820)\end{array}$ & $\begin{array}{l}-0.032 \\
(-0.759)\end{array}$ & $\begin{array}{l}-0.092 * * \\
(-2.070)\end{array}$ & $\begin{array}{c}-0.149 * * * \\
(-4.284)\end{array}$ & $\begin{array}{c}-0.174 * * * \\
(-5.537)\end{array}$ & $\begin{array}{c}-0.196 * * * \\
(-6.614)\end{array}$ \\
\hline HIGH COMPLEXITY $x$ TARP Bank & $\begin{array}{c}-0.171 * * * \\
(-2.621)\end{array}$ & $\begin{array}{l}-0.120 * * \\
(-2.562)\end{array}$ & $\begin{array}{c}-0.261 * * * \\
(-4.245)\end{array}$ & $\begin{array}{c}-0.187 * * * \\
(-4.123)\end{array}$ & $\begin{array}{l}-0.082 * \\
(-1.929)\end{array}$ & $\begin{array}{c}-0.096 * * * \\
(-2.874)\end{array}$ & $\begin{array}{l}-0.222 * * * \\
(-7.239)\end{array}$ & $\begin{array}{c}-0.187 * * * \\
(-6.411)\end{array}$ \\
\hline LOW COMPLEXITY $x$ Post TARP $x$ TARP Bank & $\begin{array}{c}-0.875 * * * \\
(-4.072)\end{array}$ & $\begin{array}{c}-0.491 * * * \\
(-3.183)\end{array}$ & $\begin{array}{c}-2.038 * * * \\
(-8.586)\end{array}$ & $\begin{array}{c}-1.244 * * * \\
(-7.358)\end{array}$ & $\begin{array}{c}-0.894 * * * \\
(-4.194)\end{array}$ & $\begin{array}{c}-0.502 * * * \\
(-3.296)\end{array}$ & $\begin{array}{c}-2.065 * * * \\
(-8.806)\end{array}$ & $\begin{array}{c}-1.267 * * * \\
(-7.624)\end{array}$ \\
\hline HIGH COMPLEXITY $x$ Post TARP $x$ TARP Bank & $\begin{array}{l}-0.403 * \\
(-1.778) \\
\end{array}$ & $\begin{array}{l}-0.217 \\
(-1.352)\end{array}$ & $\begin{array}{c}-1.375^{* * *} \\
(-5.636)\end{array}$ & $\begin{array}{c}-0.838 * * * \\
(-4.830)\end{array}$ & $\begin{array}{l}-0.445 * * \\
(-1.973)\end{array}$ & $\begin{array}{l}-0.242 \\
(-1.532)\end{array}$ & $\begin{array}{c}-1.419 * * * \\
(-5.863)\end{array}$ & $\begin{array}{c}-0.866 * * * \\
(-5.089)\end{array}$ \\
\hline Proxies for CAMELS & YES & YES & NO & NO & YES & YES & NO & NO \\
\hline Bank Controls Other than CAMELS & YES & YES & YES & YES & NO & NO & NO & NO \\
\hline Time Fixed Effects & YES & YES & YES & YES & YES & YES & YES & YES \\
\hline Observations & 7,395 & 7,269 & 7,396 & 7,270 & 7,395 & 7,269 & 7,650 & 7,513 \\
\hline Adjusted R-squared & 0.371 & 0.331 & 0.166 & 0.147 & 0.367 & 0.327 & 0.156 & 0.137 \\
\hline
\end{tabular}


Y-5

Table Y.1 Panel B2: Tests of the Equality of the Effects of TARP for Different Types of TARP Recipients

\begin{tabular}{|c|c|c|c|c|c|c|c|c|}
\hline \multirow[b]{2}{*}{ Dependent Variable: } & \multicolumn{2}{|c|}{$\begin{array}{c}\text { Main } \\
\text { Specification } \\
\end{array}$} & \multicolumn{2}{|c|}{$\begin{array}{c}\text { Excluding Proxies } \\
\text { for CAMELS }\end{array}$} & \multicolumn{2}{|c|}{$\begin{array}{c}\text { Excluding Controls } \\
\text { Other than CAMELS } \\
\end{array}$} & \multicolumn{2}{|c|}{$\begin{array}{c}\begin{array}{c}\text { Excluding All } \\
\text { Controls }\end{array} \\
\end{array}$} \\
\hline & NSRISK & SES & NSRISK & SES & NSRISK & SES & NSRISK & SES \\
\hline Independent Variables: & (1) & $(2)$ & (3) & (4) & $(5)$ & (6) & $(7)$ & (8) \\
\hline $\begin{array}{l}t \text {-stat: } \\
\text { Effect for TARP banks with low organizational } \\
\text { complexity = } \\
\text { effect for TARP banks with high organizational } \\
\text { complexity }\end{array}$ & $5.879 * * *$ & $4.866 * * *$ & $6.789 * * *$ & $6.156^{* * *}$ & $5.780 * * *$ & $4.707 * * *$ & $6.840 * * *$ & $6.255 * * *$ \\
\hline
\end{tabular}

Table Y.1 Panel C: Organizational Structure: BHC vs. Standalone Bank

Table Y.1 Panel C1: Regression Estimates

\begin{tabular}{|c|c|c|c|c|c|c|c|c|}
\hline \multirow[b]{2}{*}{ Dependent Variable: } & \multicolumn{2}{|c|}{$\begin{array}{c}\text { Main } \\
\text { Specification } \\
\end{array}$} & \multicolumn{2}{|c|}{$\begin{array}{l}\text { Excluding Proxies } \\
\text { for CAMELS }\end{array}$} & \multicolumn{2}{|c|}{$\begin{array}{l}\text { Excluding Controls } \\
\text { Other than CAMELS }\end{array}$} & \multicolumn{2}{|c|}{$\begin{array}{c}\text { Excluding All } \\
\text { Bank Controls } \\
\end{array}$} \\
\hline & NSRISK & SES & NSRISK & SES & NSRISK & SES & NSRISK & SES \\
\hline Independent Variables: & (1) & (2) & (3) & (4) & (5) & (6) & (7) & (8) \\
\hline BHC $x$ TARP Bank & $\begin{array}{c}-0.099 * * \\
(-2.017)\end{array}$ & $\begin{array}{c}-0.101 * * * \\
(-2.730)\end{array}$ & $\begin{array}{c}-0.121 * * * \\
(-2.753)\end{array}$ & $\begin{array}{c}-0.119 * * * \\
(-3.222)\end{array}$ & $\begin{array}{c}-0.085 * * \\
(-2.026)\end{array}$ & $\begin{array}{c}-0.119 * * * \\
(-3.581)\end{array}$ & $\begin{array}{c}-0.196 * * * \\
(-6.358)\end{array}$ & $\begin{array}{c}-0.188 * * * \\
(-6.463)\end{array}$ \\
\hline STANDALONE BANK $x$ TARP Bank & $\begin{array}{l}-0.119 * \\
(-1.808)\end{array}$ & $\begin{array}{l}-0.120 * * \\
(-2.538)\end{array}$ & $\begin{array}{c}-0.137 * * \\
(-2.416)\end{array}$ & $\begin{array}{c}-0.125 * * * \\
(-2.727)\end{array}$ & $\begin{array}{l}-0.103^{*} \\
(-1.737)\end{array}$ & $\begin{array}{c}-0.147 * * * \\
(-3.574)\end{array}$ & $\begin{array}{c}-0.256 * * * \\
(-7.454)\end{array}$ & $\begin{array}{c}-0.242 * * * \\
(-7.718)\end{array}$ \\
\hline BHC $x$ Post TARP $x$ TARP Bank & $\begin{array}{c}-0.627 * * * \\
(-2.873)\end{array}$ & $\begin{array}{c}-0.349 * * \\
(-2.246)\end{array}$ & $\begin{array}{c}-1.659 * * * \\
(-7.013)\end{array}$ & $\begin{array}{c}-1.013 * * * \\
(-6.012)\end{array}$ & $\begin{array}{c}-0.674 * * * \\
(-3.124)\end{array}$ & $\begin{array}{c}-0.382 * * \\
(-2.498)\end{array}$ & $\begin{array}{c}-1.701 * * * \\
(-7.271)\end{array}$ & $\begin{array}{c}-1.044 * * * \\
(-6.313)\end{array}$ \\
\hline STANDALONE BANK $x$ Post TARP $x$ TARP Bank & $\begin{array}{c}-0.733 * * * \\
(-3.243)\end{array}$ & $\begin{array}{l}-0.355 * * \\
(-2.257)\end{array}$ & $\begin{array}{c}-2.416^{* * *} \\
(-10.118)\end{array}$ & $\begin{array}{c}-1.476 * * * \\
(-8.751)\end{array}$ & $\begin{array}{c}-0.783 * * * \\
(-3.465)\end{array}$ & $\begin{array}{l}-0.392 * * \\
(-2.502)\end{array}$ & $\begin{array}{c}-2.504 * * * \\
(-10.624)\end{array}$ & $\begin{array}{c}-1.553 * * * \\
(-9.374)\end{array}$ \\
\hline Proxies for CAMELS & YES & YES & No & No & YES & YES & No & No \\
\hline Bank Controls Other than CAMELS & YES & YES & YES & YES & No & NO & NO & No \\
\hline Other Government Programs & YES & YES & YES & YES & No & No & No & No \\
\hline Time Fixed Effects & YES & YES & YES & YES & YES & YES & YES & YES \\
\hline Observations & 7,395 & 7,269 & 7,396 & 7,270 & 7,395 & 7,269 & 7,650 & 7,513 \\
\hline Adjusted R-squared & 0.368 & 0.328 & 0.164 & 0.146 & 0.362 & 0.322 & 0.152 & 0.133 \\
\hline
\end{tabular}


Y-6

Table Y.1 Panel C2: Tests of the Equality of the Effects of TARP for Different Types of TARP Recipients

\begin{tabular}{|c|c|c|c|c|c|c|c|c|}
\hline \multirow[b]{2}{*}{ Dependent Variable: } & \multicolumn{2}{|c|}{$\begin{array}{c}\text { Main } \\
\text { Specification } \\
\end{array}$} & \multicolumn{2}{|c|}{$\begin{array}{c}\text { Excluding Proxies } \\
\text { for CAMELS }\end{array}$} & \multicolumn{2}{|c|}{$\begin{array}{l}\text { Excluding Controls } \\
\text { Other than CAMELS } \\
\end{array}$} & \multicolumn{2}{|c|}{$\begin{array}{c}\text { Excluding All } \\
\text { Bank Controls } \\
\end{array}$} \\
\hline & NSRISK & SES & NSRISK & SES & NSRISK & SES & NSRISK & SES \\
\hline Independent Variables: & (1) & (2) & (3) & (4) & (5) & (6) & (7) & (8) \\
\hline $\begin{array}{l}\boldsymbol{t} \text {-stat: } \\
\text { Effect for TARP institutions that are BHC = } \\
\text { effect for TARP institutions that are } \\
\text { standalone banks }\end{array}$ & 1.261 & 0.100 & $9.387 * * *$ & $8.803 * * *$ & 1.285 & 0.200 & $11.105^{* * * *}$ & $11.173 * * *$ \\
\hline
\end{tabular}

Table Y.1 Panel D: Internationalization: International Banks vs. Purely Domestic Banks

Table Y.1 Panel D1: Regression Estimates

\begin{tabular}{|c|c|c|c|c|c|c|c|c|}
\hline \multirow[b]{2}{*}{ Dependent Variable: } & \multicolumn{2}{|c|}{$\begin{array}{c}\text { Main } \\
\text { Specification }\end{array}$} & \multicolumn{2}{|c|}{$\begin{array}{c}\text { Excluding Proxies } \\
\text { for CAMELS }\end{array}$} & \multicolumn{2}{|c|}{$\begin{array}{c}\text { Excluding Controls } \\
\text { Other than CAMELS }\end{array}$} & \multicolumn{2}{|c|}{$\begin{array}{c}\text { Excluding All } \\
\text { Bank Controls }\end{array}$} \\
\hline & NSRISK & SES & NSRISK & SES & NSRISK & SES & NSRISK & SES \\
\hline Independent Variables: & (1) & $(2)$ & (3) & (4) & $(5)$ & (6) & $(7)$ & (8) \\
\hline International x TARP Bank & $\begin{array}{l}0.150^{*} \\
(1.744)\end{array}$ & $\begin{array}{c}0.069 \\
(1.112)\end{array}$ & $\begin{array}{c}0.354 * * * \\
(4.012)\end{array}$ & $\begin{array}{c}0.204 * * * \\
(3.035)\end{array}$ & $\begin{array}{c}0.031 \\
(0.494)\end{array}$ & $\begin{array}{l}-0.106^{* *} \\
(-2.338)\end{array}$ & $\begin{array}{c}-0.134 * * * \\
(-3.942)\end{array}$ & $\begin{array}{c}-0.206^{* * * *} \\
(-6.585)\end{array}$ \\
\hline Purely Domestic x TARP Bank & $\begin{array}{l}-0.120 * * \\
(-2.482)\end{array}$ & $\begin{array}{c}-0.116^{* * * *} \\
(-3.149)\end{array}$ & $\begin{array}{c}-0.159 * * * \\
(-3.632)\end{array}$ & $\begin{array}{c}-0.143 * * * \\
(-3.891)\end{array}$ & $\begin{array}{l}-0.100 * * \\
(-2.389)\end{array}$ & $\begin{array}{c}-0.122 * * * \\
(-3.697)\end{array}$ & $\begin{array}{c}-0.207 * * * \\
(-6.736)\end{array}$ & $\begin{array}{c}-0.189 * * * \\
(-6.498)\end{array}$ \\
\hline International $x$ Post TARP $x$ TARP Bank & $\begin{array}{c}-0.955 * * * \\
(-3.939)\end{array}$ & $\begin{array}{c}-0.549 * * * \\
(-3.136)\end{array}$ & $\begin{array}{c}-2.310 * * * \\
(-8.974)\end{array}$ & $\begin{array}{c}-1.420 * * * \\
(-7.727)\end{array}$ & $\begin{array}{c}-0.954 * * * \\
(-3.953)\end{array}$ & $\begin{array}{c}-0.536 * * * \\
(-3.078)\end{array}$ & $\begin{array}{c}-2.319 * * * \\
(-9.158)\end{array}$ & $\begin{array}{c}-1.431 * * * \\
(-7.938)\end{array}$ \\
\hline Purely Domestic $x$ Post TARP $x$ TARP Bank & $\begin{array}{c}-0.589 * * * \\
(-2.696) \\
\end{array}$ & $\begin{array}{l}-0.323 * * \\
(-2.079)\end{array}$ & $\begin{array}{c}-1.625 * * * \\
(-6.863) \\
\end{array}$ & $\begin{array}{c}-0.989 * * * \\
(-5.859)\end{array}$ & $\begin{array}{c}-0.641 * * * \\
(-2.965)\end{array}$ & $\begin{array}{l}-0.358 * * \\
(-2.342)\end{array}$ & $\begin{array}{c}-1.675 * * * \\
(-7.154)\end{array}$ & $\begin{array}{c}-1.026 * * * \\
(-6.200)\end{array}$ \\
\hline Proxies for CAMELS & YES & YES & No & NO & YES & YES & No & No \\
\hline Bank Controls Other than CAMELS & YES & YES & YES & YES & NO & NO & NO & No \\
\hline Other Government Programs & YES & YES & YES & YES & NO & No & No & No \\
\hline Time Fixed Effects & YES & YES & YES & YES & YES & YES & YES & YES \\
\hline $\begin{array}{l}\text { Observations } \\
\text { Adjusted R-squared }\end{array}$ & $\begin{array}{l}7,395 \\
0.369\end{array}$ & $\begin{array}{l}7,269 \\
0.329\end{array}$ & $\begin{array}{l}7,396 \\
0.163\end{array}$ & $\begin{array}{l}7,270 \\
0.145\end{array}$ & $\begin{array}{l}7,395 \\
0.363\end{array}$ & $\begin{array}{l}7,269 \\
0.323\end{array}$ & $\begin{array}{l}7,650 \\
0.151\end{array}$ & $\begin{array}{l}7,513 \\
0.133\end{array}$ \\
\hline
\end{tabular}




$$
\mathrm{Y}-7
$$

Table Y.1 Panel D2: Tests of the Equality of the Effects of TARP for Different Types of TARP Recipients

\begin{tabular}{|c|c|c|c|c|c|c|c|c|}
\hline \multirow[b]{2}{*}{ Dependent Variable: } & \multicolumn{2}{|c|}{$\begin{array}{c}\text { Main } \\
\text { Specification } \\
\end{array}$} & \multicolumn{2}{|c|}{$\begin{array}{l}\text { Excluding Proxies } \\
\text { for CAMELS }\end{array}$} & \multicolumn{2}{|c|}{$\begin{array}{l}\text { Excluding Controls } \\
\text { Other than CAMELS }\end{array}$} & \multicolumn{2}{|c|}{$\begin{array}{c}\text { Excluding All } \\
\text { Bank Controls } \\
\end{array}$} \\
\hline & NSRISK & SES & NSRISK & SES & NSRISK & SES & NSRISK & SES \\
\hline Independent Variables: & (1) & $(2)$ & (3) & $(4)$ & $(5)$ & $(6)$ & $(7)$ & (8) \\
\hline $\begin{array}{l}\boldsymbol{t} \text {-stat: } \\
\text { Effect for TARP banks that are international = } \\
\text { effect for TARP banks that are purely } \\
\text { domestic }\end{array}$ & $2.951 * * *$ & $2.484 * *$ & $5.473 * * *$ & $4.783 * * *$ & $2.561 * * *$ & $1.990 * *$ & $5.454 * * *$ & $4.768 * * *$ \\
\hline
\end{tabular}

